
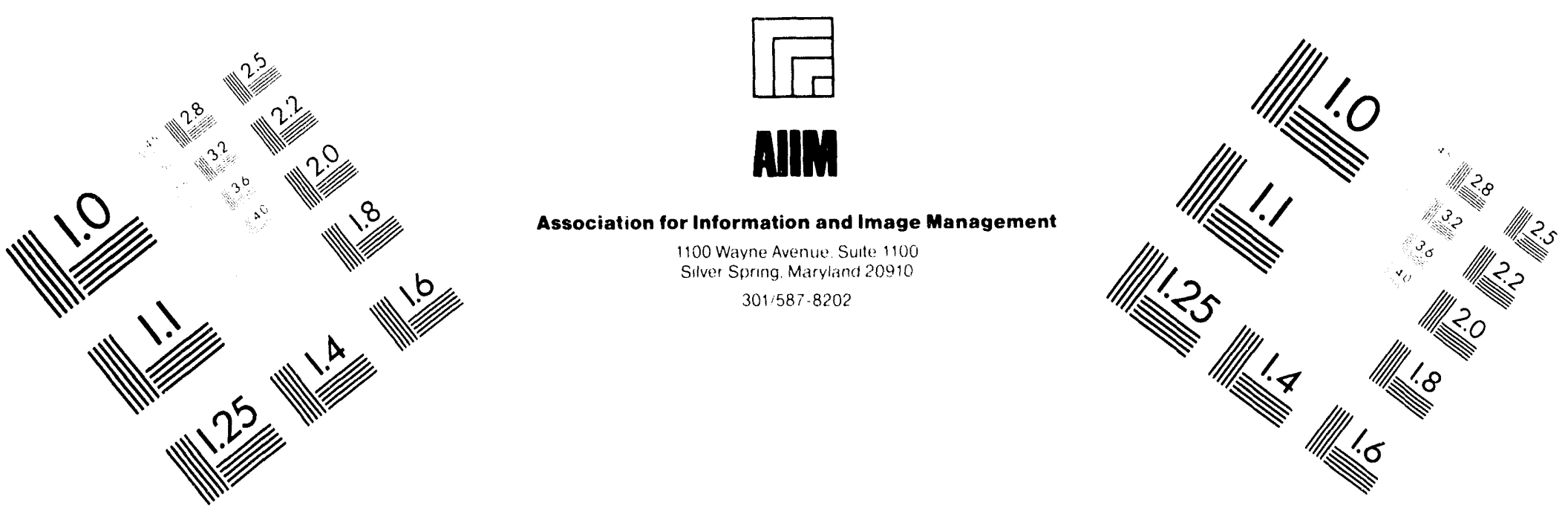

\title{
Centimeter
}

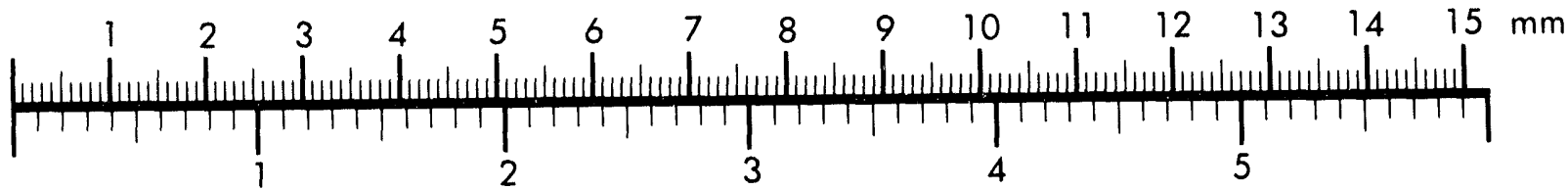

Inches
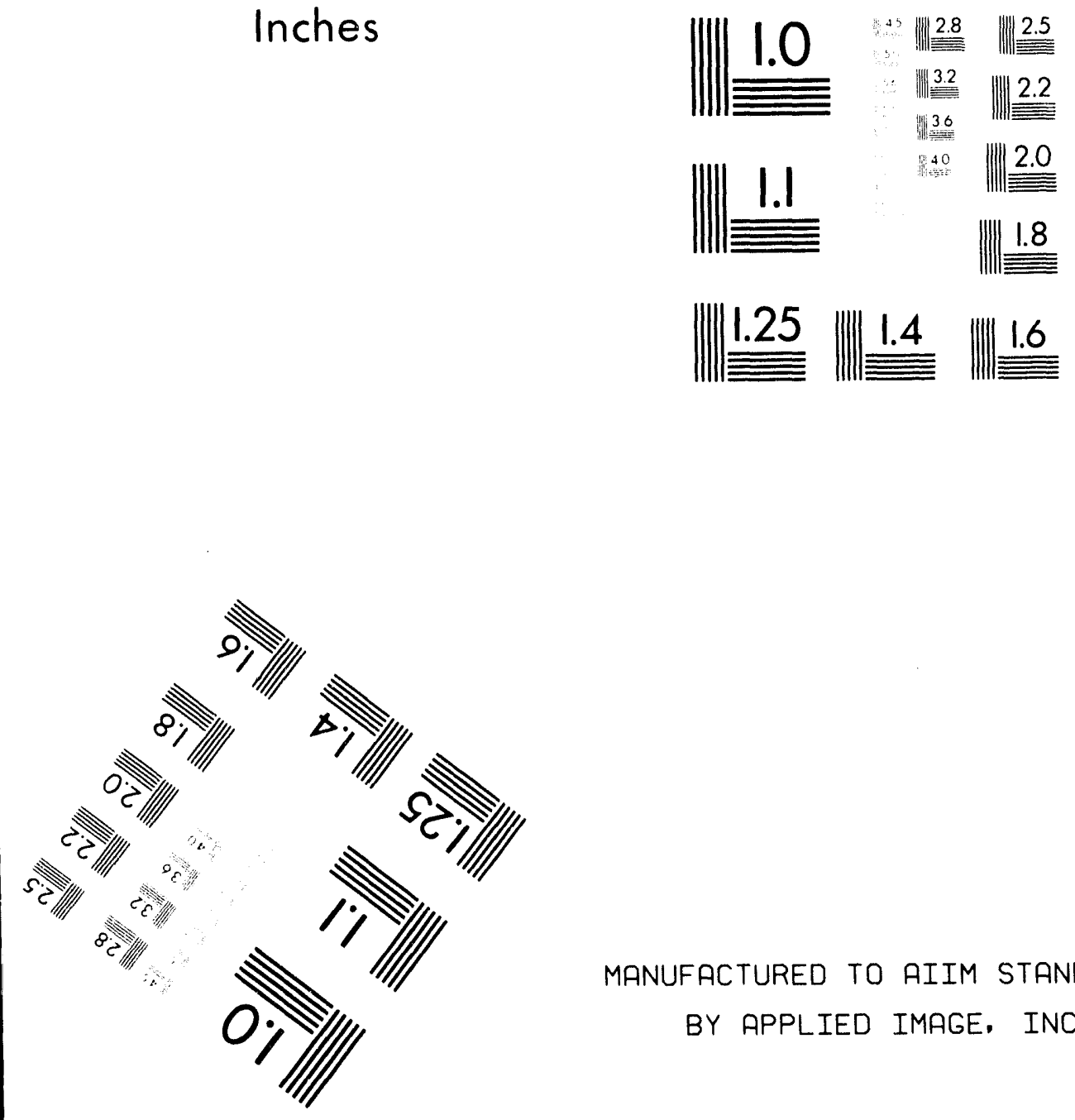

MANUFACTURED TO AIIM STANDARDS

BY APPLIED IMAGE, INC.

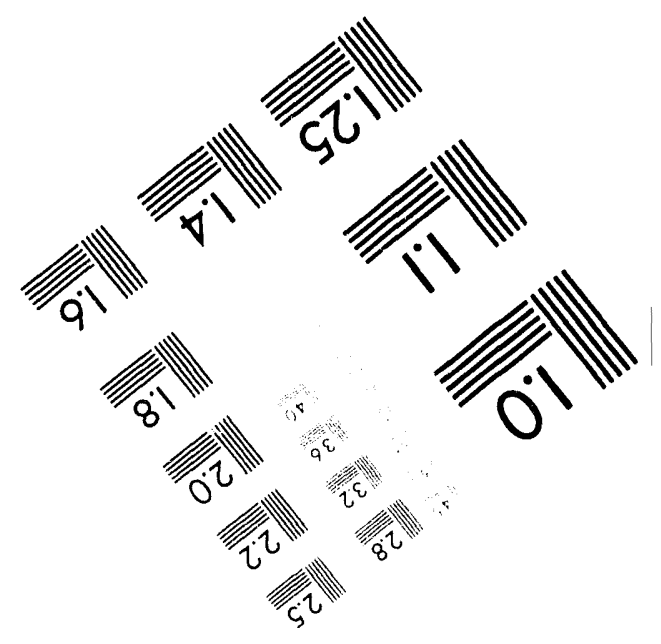



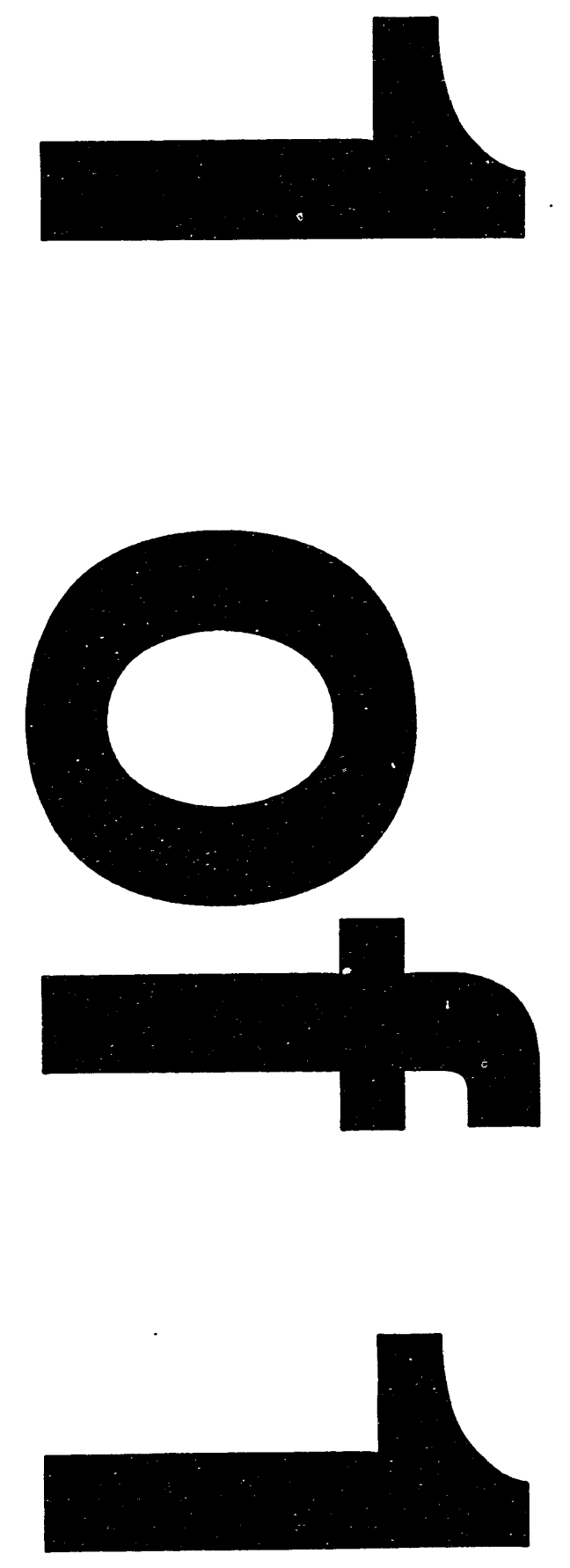


\title{
U.S. DEPARTMENT OF THE INTERIOR
}

U.S. GEOLOGICAL SURVEY

\section{CHARACTERIZING FRACTURED ROCK FOR FLUID-FLOW, GEOMECHANICAL, AND PALEOSTRESS MODELING: METHODS AND PRELIMINARY RESULTS FROM YUCCA MOUNTAIN, NEVADA}

By

C.C. Barton ${ }^{1}$, Eric Larsen ${ }^{2}$,W.R. Page ${ }^{1}$, and T.M. Howard ${ }^{2}$

GEOLOGICAL SURVEY OPEN-FILE REPORT 93-269

\section{DISCLAIMER}

\begin{abstract}
This report was prepared as an account of work sponsored by an agency of the United States Government. Neither the United States Government nor any agency thereof, nor any of their employees, makes any warranty, express or implied, or assumes any legal liability or responsibility for the accuracy, completeness, or usefulness of any information, apparatus, product, or process disclosed, or represents that its use would not infringe privately owned rights. Reference herein to any specific commercial product, process, or service by trade name, trademark, manufacturer, or otherwise does not necessarily constitute or imply its endorsement, recommendation, or favoring by the United States Government or any agency thereof. The views and opinions of authors expressed herein do not necessarily state or reflect those of the United States Government or any agency thereof.
\end{abstract}

\footnotetext{
${ }^{1}$ U.S. Geological Survey, Denver, CO

${ }^{2}$ Formerly with Fenix \& Scisson, Inc., Mercury, NV
}

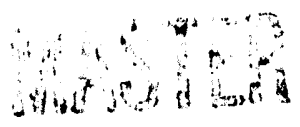


Copies of this Open-File Report

may be purchased from

U.S. Geological Survey

Open-File Reports-ESIC

Box 25425, Federal Center

Denver, CO 80225

PREPAYMENT IS REQUIRED

Price information will be published in the monthly listing

New Publications of the Geological Survey

FOR ADDITIONAL ORDERING INFORMATION

CALL: (303) 236-7476 


\section{CONTENTS}

Abstract

Introduction

Purpose of study

Previous mapping of fracture networks

Relevance of pavement method to fluid-flow and geomechanical models

Fracture terminology

Geologic setting

Location of pavements

Clearing and mapping of pavements

Fracture-network maps

Fracture characteristics

Orientation

Fracture-surface roughness

Fracture aperture

Fracture-trace length

Fracture-length density

Fracture mineralization and alteration

Fracture connectivity

Fracture history

Tubular structures

Fractal geometry of the fracture networks

Pattern of development of fracture networks

Discussion

Conclusions

Acknowledgments

References cited

Appendix

\section{Plate}

(Plate is in pocket)

1. Fracture-trace maps for pavements 100,200 , and 300

\section{FIGURES}

1. Index map showing location of study area at Yucca Mountain, southern Nevada

2. Geologic map of the area immediately surrounding drill hole USW G-4 showing the location of pavements 100,200 , and 300

3. Contoured lower-hemisphere equal-area projection of poles for pavement 100:

$A$, Fractures and joints; $B$, Joints only; $C$, Fractures only

4. Contoured lower-hemisphere equal-area projection of poles for pavement 200:

$A$, Fractures and joints; $B$, Joints only; $C$, Fractures only

5. Contoured lower-hemisphere equal-area projection of poles for pavement 300:

$A$. Fractures and joints; $B$, Joints only; $C$. Fractures only

6. Contoured lower-hemisphere equal-area projection of poles for pavements 100,200 , and 300 combined: $A$, Fractures and joints; $B$, Joints only; $C$, Fractures only

7. Photograph of "shape copier" used to record fracture surface roughness

8. Profiles of fracture-surface roughness: $A$, Typical profiles traced from field notebook with roughness coefficients; $B$, Roughness coefficient ranges for typical roughness profiles 
9. Frequency histogram of roughness coefficient for joints and fractures fitted with normal curves:

$A$, Pavement 100; $B$, Pavement 200; $C$, Pavement 300

10. Frequency of fracture aperture for pavements 100,200 , and 300

11. Rose diagrams of aperture as a function of the azimuth of fracture opening:

$A$, Pavement $100 ; B$, Pavement 200; $C$, Pavement 300

12. Frequency of fracture-trace length for pavements 100,200 , and 300

13. Diagram of aperture as a function of trace length: $A$, Pavement $100 ; B$, Pavement $200 ; C$, Pavement 300

14. Ternary diagram of percentages of fracture intersections and terminations for pavements 100,200 , and 300 ... 36

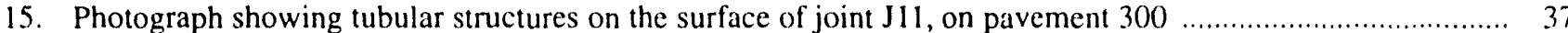

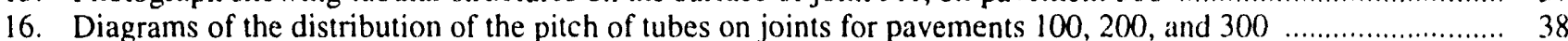

17. Plan view of a portion of a joint surface showing the direction and angle of dip for island surfaces ................. 39

18. Fractal plot of fracture networks mapped on pavements 100,200 , and 300 , and for the fault network mapped by Scott and Bonk (1985)

\section{TABLES}

1. Normal-curve constants for fracture roughness coefficient

2. Power-law constants for trace length and aperture

3. Proportions of Fracture Intersections and terminations 


\title{
Characterizing Fractured Rock for Fluid-flow, Geomechanical, and Paleostress Modeling: Methods and Preliminary Results from Yucca Mountain, Nevada
}

\author{
By C.C. Barton, U.S. Geological Survey; Eric Larsen, formerly with Fenix \& Scisson, Inc.;
} W.R. Page, U.S. Geological Survey; andT.M. Howard, formerly with Fenix and Scisson, Inc.

\section{Abstract}

Fractures have been characterized for fluidflow, geomechanical, and paleostress modeling at three localities in the vicinity of drill hole USW G-4 at Yucca Mountain in southwestern Nevada. A method for fracture characterization is introduced that integrates mapping fracture-trace networks and quantifying eight fracture parameters: trace length, orientation, connectivity, aperture, roughness, shear offset, trace-length density, and mineralization.

\section{A complex network of fractures was} exposed on three $214-$ to $260-\mathrm{m}^{2}$ pavements cleared of debris in the upper lithophysal unit of the Tiva Canyon Member of the Miocene Paintbrush Tuff. The pavements are two-dimensional sections through the three-dimensional network of strata-bound fractures. All fractures with trace lengths greater than $0.2 \mathrm{~m}$ were mapped and studied.

The networks consist of two fracture types. The first type is distinguished by low surfaceroughness coefficients and by open, anastomosing, matched half-tubes on opposing fracture faces These fractures show only face separation without shear and are termed joints. Spherulites adjacent to joint faces suggest that the joints formed, opened, and their surfaces were quenched before or during devitrification of the tuff. The tubular structure is interpreted to be analogous to breadcrust structure on volcanic bombs. The cooling joints make up two well-defined sets striking 25 to $85^{\circ}$ and 270 to $355^{\circ}$, both dipping perpendicular (plus or minus $6^{\circ}$ ) to foliation. Abutting of the two sets against each other suggests that they developed coevally. Both sets exhibit 3-to 5-m-wide swarms spaced 150-200 m apart. The second fracture type is distinguished by higher surface-rough- ness coefficients and by the absence of tubular structures on fracture faces. A few of these fractures have demonstrable shear offset and are thus termed faults. For most of these fractures, it was not possible to determine whether there was any shear displacement, and they are referred to as fractures. The fractures abut against and the faults offset the cooling joints and thus both postdate the joints. Unlike the cooling joints, the fractures do not define sets based on orientation or surface roughness.

The frequency distribution of surfaceroughness coefficient ( $R C$ ) for fractures and faults combined is fitted with a normal distribution and peaks at $\mathrm{RC}=10$. The $\mathrm{RC}$ frequency distribution for the cooling joints is also fitted with a normal distribution and peaks at $R C=2$. The aperture frequency and trace-length frequency are best fitted by power laws. Anisotropy in aperture for the fracture networks is interpreted to result from a combination of tectonic and topographic stresses.

The spatial patchiness of fractures, joints, and faults in each of the networks is shown to be fractal, and the fractal dimensions D are 1.5, 1.4, 1.5 .

\section{INTRODUCTION}

\section{Purpose of Study}

Fracture studies are part of the U.S. Geological Survey's effort to characterize the geologic and hydrologic framework at Yucca Mountain, Nevada (fig. 1). The site is currently being evaluated by the U.S. Department of Energy as a potential underground repository for high-level radioactive waste.

The impetus for this study is three-fold. First, hydrologic flow through fracture networks is a means 


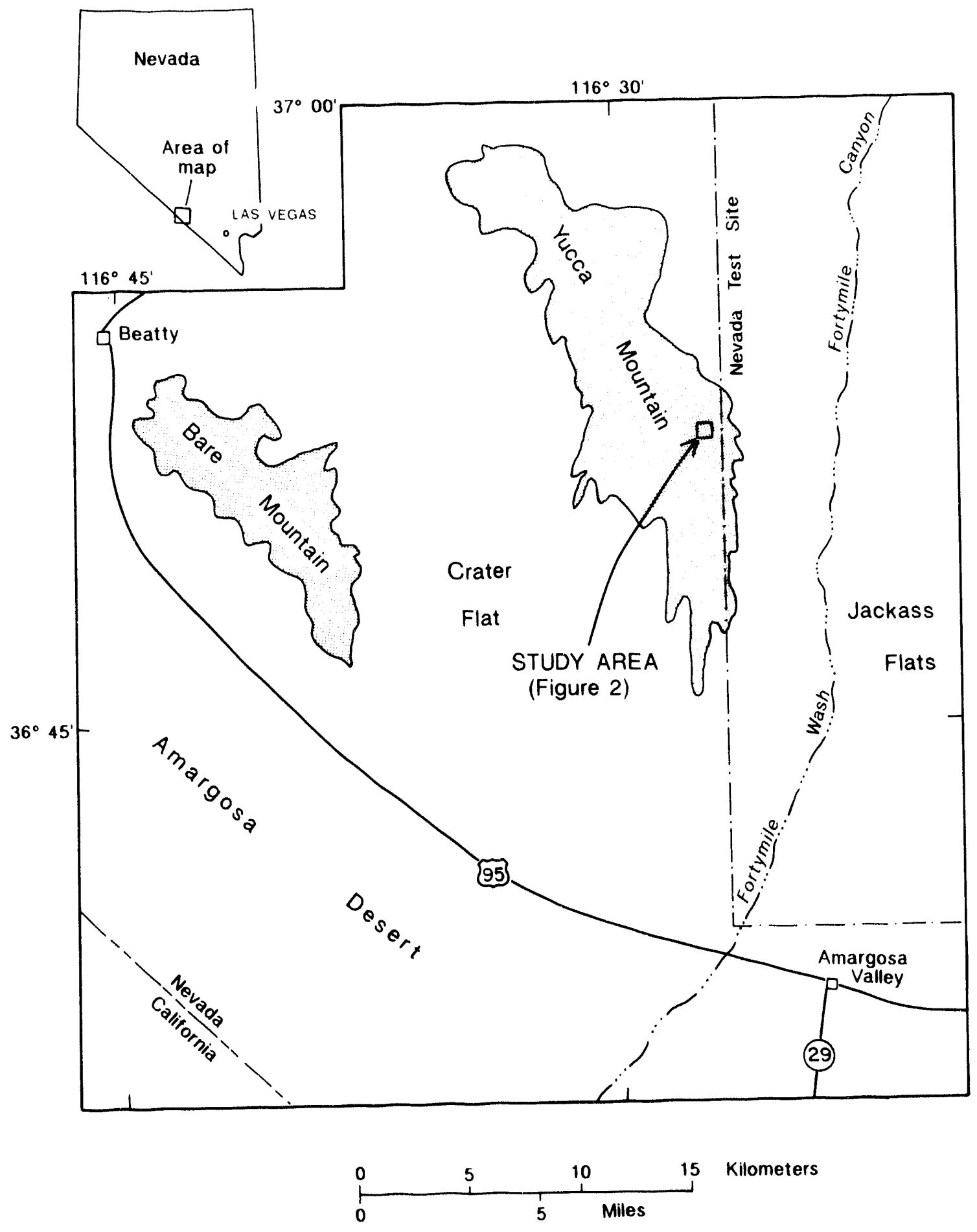

Figure 1. Index map showing location of study area at Yucca Mountain, southern Nevada.

2 Characterizing Fractured Rock for Fluid-flow, Geomechanical, and Paleostress Modeling: Methods and Preliminary Results from Yucca Mountain, Nevada 
by which water could reach buried radioactive waste and transport radionuclides out of the repository. Open networks are the primary avenues for gases and large fluxes of liquids through rock masses. In contrast to fracture-network flow, rock-matrix flow of water generally is significant only for small fluxes, such as are believed to predominate through much of the unsaturated-zone thickness in the volcanic tuffs at Yucca Mountain (Montazer and Wilson, 1984). However, fracture flow probably occurs episodically in the near-surface welded tuffs and reasonably could be expected under future climates similar to those of the Pleistocene, in this region. Saturated network permeabilities estimated from gas-injection tests in the tuffs are six to seven orders of magnitude greater than artificially saturated matrix permeabilities (Montazer and Wilson, 1984). Precipitation of minerals from aqueous solutions along fractures indicates that, in the geologic past, water has moved through Yucca Mountain along fractures.

Second, because the mountain is composed of fracture-bounded blocks over a wide range of size scales, the mechanical stability of the mountain during and after the construction of an underground repository depends in part on the geometry of the fracture networks.

Third, the fracture netw'ork is a composite of sequential fracture formation and reactivation events (Barton and others, 1986), which record parts of the paleostress history of the mountain.

Characterization of fractures for fluid-flow, geomechanical, and paleostress models now in use or under development cannot be achieved by what have been the standard geologic methods of study. The standard methods, such as those outlined in Kulander and others (1979), are based only on sampling natural outcrops and cores and do not include mapping of the fracture-trace patterns. While outcrop and core studies do permit characterization of orientation, aperture, and roughness, they do not permit characterization of trace length, spatial distribution, interconnectivity, or the size and shape of fracture-bounded biocks; all of which can be measured from a fracture-trace map of a pavement surface. All of the characteristics listed above are necessary for fluid-flow, geomechanical, and paleostress modeling.

Fracture networks in rock are volumetric, they partially fill volume space. Complete volumetric (three-dimensional) sampling over a wide range of length scales would be ideal, but is not technically possible nor physically practical. The pavements are two-dimensional sections through three-dimensional fracture networks. Cores are one-dimensional samples, and small outcrops are point samples which are zero- dimensional. The pavements permit sampling that is one integer dimension removed from the dimensionality of the networks. Core and outcrop samples are each further dimensionally removed.

\section{Previous Mapping of Fracture Networks}

Maps of fracture traces that adequately sample a fracture network are rare. The only such published maps that we are aware of are contained in four papers. Segall and Pollard (1983a and 1983b) mapped fracture traces on glacial pavements in the Mount Givens granodiorite in the Sierra Nevada of California. La Pointe and Hudson (1985) mapped fractures on a quarry floor in the Niagaran dolomite at Lannon, Wisconsin. Olson and Pollard (1989) mapped fracture traces in the Rico Limestone near Mexican Hat, Utah. All other published maps that we are aware of do not adequately sample the fracture network because one dimension of the map is too small, or because the range in fracture trace length mapped was too small. An optimal map would be equidimensional. Our own maps only approach this optimal shape. Therefore, in order to adequately sample the fracture network, we have mapped all fractures from the largest down to $0.2 \mathrm{~m}$. We have sought to exclude weathering induced fractures and mapped only those fractures that we believe would be present in the same stratigraphic unit prior to exposure and weathering as described below.

\section{Relevance of Pavement Method to Fluid-flow and Geomechanical Models}

Contemporary fluid-flow and geomechanical models are generalized anci utilize simulated networks (Long, 1983; Robinson, 1984; Long and others, 1985; Goodman and Shi, 1985; Lemos and others, 1985; Dershowitz and others, 1991). Site-specific models require site-specific fracture parameters. The method of pavement studies described below is the best basis for complete fracture characterization. The pavement method characterizes eight integrated fracture parameters. Published fluid-flow and geomechanical models are still too primitive to incorporate all of the parameters. The relevance of the parameters is discussed as they are introduced below, and foretells their incorporation in more sophisticated models in the future. It is not the intention of this report to present contemporary fluidflow, geomechanical, or paleostress models or to detail how the fracture parameters discussed below are incorporated into such models. We encourage those interested in modeling to begin with the references cited at 
the heginning of this paragraph. Our purpose is to introduce the reader to the relevant fracture characteristics and to methods by which they can be measured in the field and represented quantitatively.

\section{Fracture Terminology}

Fractures, joints, and faults form a threedimensional interconnected network in nearly all rocks at or near the earth's surface. We use the terms, fracture, joint, and fault as follows. Fracture is the general term for a mechanically, chemically, or thermally induced planar or curviplanar parting in rock (excluding cleavage). Fractures whose opposing faces have demonstrable shear offset greater than the normalopening are termed faults. Fractures whose opposing faces have demonstrable normal-opening offset (without shear $\mathrm{cr}$ with shear less than the normal-opening) are termed joints. The term fracture is used below in the general sense where the offset cannot be determined and thus includes joints and faults, except where joints or faults are specified.

\section{GEOLOGIC SETTING}

Yucca Mountain is in the southern part of the Great Basin subprovince of the Basin and Range physiographic province. It is composed primarily of stratified Miocene volcanic ash-flow and ash-fall tuffs. The volcanic section locally ranges from about 1 to $4 \mathrm{~km}$ thick and lies unconformably, or perhaps in fault contact (Scott, 1986), on older Paleozoic sedimentary rocks. The complete volcanic stratigraphic section exposed at Yucca Mountain is described in Scott and Bonk (1984). All three pavements are in the úensely welded, upper lithophysal unit of the Tiva Canyon Member of the Miocene Paintbrush Tuff. The source of the 13-Ma (R. B. Scott, U.S. Geological Survey, oral commun., 1986) Tiva Canyon tuffs is thought to be the Claim Canyon caldera, $2 \mathrm{~km}$ to the north (Byers and others, 1976).

Basin and Range extension began about 40 Ma in the region north of Yucca Mountain and was widespread in the southern Great Basin throughout Miocene time, 24 to 5 m.y. ago (U.S. Geological Survey, 1984). Structurally, Yucca Mountain consists of a series of elongate north-trending blocks bounded by major westdipping normal faults, along which the blocks have been tilted eastward. Swarms of steeply dipping normal faults, each with small offset (normally less than $10 \mathrm{~m}$ ), are common in the southern half of the mountain (Scott, 1984). The central part of the mountain is relatively unfaulted. The northern end of the mountain is cut diagonally by four northwest-trending valleys, probably strike-slip faults, possibly formed as part of the Las Vegas Valley-Walker Lane shear deformation (Scott and others, 1984).

Many of the normal faults on Yucca Mountain and in the region exhibit obliquely pitching striations on slickensided surfaces (R. B. Scolt, U.S. Geological Survey, oral commun., 1989). If the striations are due to reactivation of the faults, then the implication is that the direction of regional extension has not remained fixed, but rather has moved within the northwestsoutheast quadrants through time.

The study area is located in the central part of the mountain (fig. 1). We remapped the volcanic stratigraphy of Scott and Bonk (1984) in the study area (fig. 2) using altimeters to accurately plot stratigraphic contacts directly on a metric topographic base (Wu, 1985). The units are those defined and described by Scott and Bonk (1984). The only significant fault in the study area is the north-south-striking, steeply west-dipping Ghost Dance fault. The vertical offset on this normal fault decreases northward from about $8 \mathrm{~m}$ on the north side of Live Yucca Ridge to about $4 \mathrm{~m}$ on the south side of Dead Yucca Ridge (fig. 2). In the study area, the tuff foliation strikes $18^{\circ} \mathrm{E}$ and dips $8^{\circ}$ southeast.

\section{Location of Pavements}

We prepared 1:50-scale maps of fracture traces at three sites in the immediate vicinity of drill hole USW G-4. The exposed bedrock pavements are designated 100, 200, and 300. Pavement 100 is on Live Yucca Ridge $500 \mathrm{~m}$ south of pavements 200 and 300 , which are $15 \mathrm{~m}$ apart on Dead Yucca Ridge (fig. 2). The location of the pavements in Nevada state plane coordinates are: Pavement 100, N-765,345 E-561,870; Pavement 200, N-766,854 E-562,237; Pavement 300, N-766,854 E-562,362 (Science Applications International, 1988).

\section{CLEARING AND MAPPING OF PAVEMENTS}

In order to map the fracture networks, we cleared three nearly horizontal pavements to expose large areas of bedrock. The location of these pavements was governed by the desire to study fractures in the upper lithophysal unit, by the thinness of the debris layer to be removed (less than $12 \mathrm{~cm}$ at these locations), and by accessibility for the pumper truck used for hydraulic clearing. The size of each pavement was governed by the scale of the fracture pattern and thickness of debris 
$1 / 1900 m$

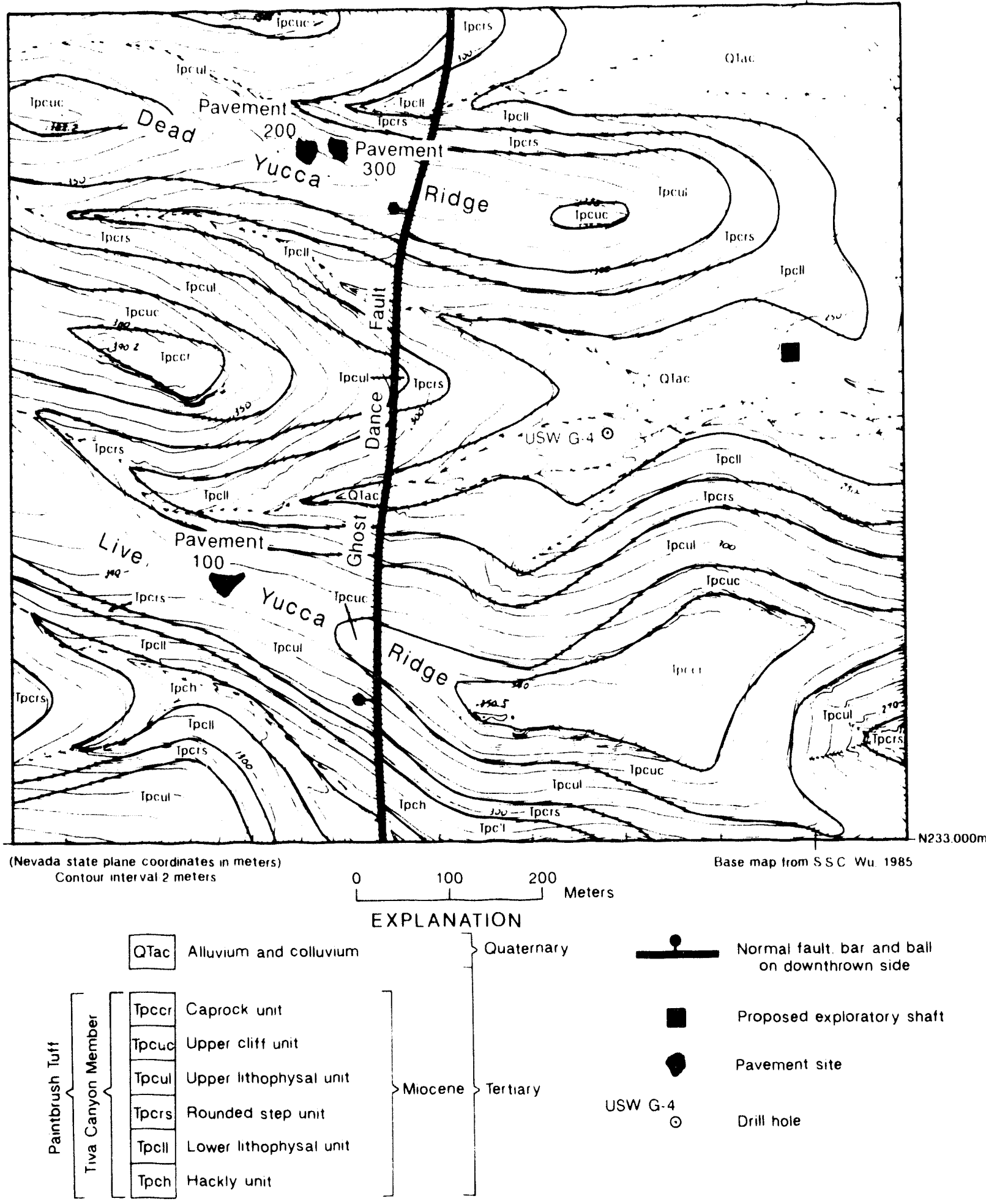

Figure 2. Geologic map of the area immediately surrounding drill hole USW G-4 showing the location of pavements 100,200 , and 300 . 
cover. Pavement 100 is $214 \mathrm{~m}^{2}$ in area, pavement 200 is $260 \mathrm{~m}^{2}$, and pavement 300 is $221 \mathrm{~m}^{2}$.

Clearing of the pavements was done in two steps. First, all large boulders and brush were removed by hand. Second, rock debris and soil were removed using pressurized water sprayed from a firehose. The total volume of water used to clear these three pavements was $170 \mathrm{~m}^{3}$ dispersed over an area of approximately $3,500 \mathrm{~m}^{2}$. The area of dispersal is necessarily larger than the area of the pavements, because it includes the area of spray and runoff. Additional cleaning was done on a pavement using small brooms and brushes. The fracture network was thus completely exposed for mapping and study.

\section{FRACTURE NETWORK MAPS}

The bases for mapping the pavements were aerial photographs taken from a helicopter at an altitude of approximately $150 \mathrm{~m}$. The orientation and scale of the bases were determined directly from 2-m-long, $0.22-\mathrm{m}$-wide arrows placed on the pavements and oriented to true north before the aerial photographs were laken. Where the aerial photograph was not normal to a pavement surface, we rectified the maps by redrafting them on large rubber sheets which were stretched over a wooden frame so as to uniformly remove distortion of the arrows and to restore lengths and angles between fractures on the map to those measured directly on the pavement. For all rectified maps, the resulting angle changes were less than four percent and length changes were less that three percent of the actual values measured directly on the pavements.

We mapped while standing on the pavements, adding fractures not visible on the aerial photographs. All fractures more than $0.2 \mathrm{~m}$ long were mapped on clear acetate sheets laid over the aerial photo bases. All fractures were mapped because we could not know which fractures were hydrologically significant. All fracture studies and maps necessarily must select some lower cutoff; we chose 0.2 meters for three reasons. First, the number of fractures increases with decreasing trace length as a power-law function, as can be seen on figure 12, the number of fractures increases dramatically below $0.2 \mathrm{~m}$ and approaches infinity as trace length goes to zero. The time required to map fractures would increase proportionately, and so we set $0.2 \mathrm{~m}$ as our lower cutoff in the interest of studying a number of pavements rather than focusing on just one. Second, a length of $0.2 \mathrm{~m}$ is approximately the lower limit of length that can be easily resolved on maps at the scale of publication. Third, at length scales shorter than $0.2 \mathrm{~m}$ there is a large population of fractures due 10 weathering which we sought to exclude from this study. We paid careful attention to mapping fracture intersections, abutments, and offset relationships. Because all fracture traces, intersections, and endings were mapped in detail on the pavement surface, the maps and data contained in this report are an uncensored sample of the exposed fracture population greater than 0.2 meters in trace length.

The pavement surfaces are not significantly weathered. Shallow dipping, bowl-shaped fractures exhibit fresh surfaces and therefore we consider them to be due to weathering, and they were excluded from this study. Fractures that are mineralized, coated, or stained were considered to be formed by geologic processes other than surface exposure and were included in our study. Calcrete deposits coat and infill all types of fractures exposed on the pavements, and so its presence was not used to discriminate between fractures due to weathering and those due to other geologic processes.

Plate 1 shows the maps for the lhree pavements. Each fracture is designated by a letter and number. The joints are designated by the letter $J$, and all other fractures by the letter $F$. Numbers with decimal fractions (for example, J40.1 on pavement 100) label individual segments of fractures that have been offset by later fractures. Numbers followed by a letter (for example, F60a and F60b on pavement 100) are used to label straight segments of fractures traces with strong curvature. Our segmentation of a strongly curved fracture trace into straight segments was done visually in order that the orientation of the fracture could be more accurately represented using strike and dip, a method which represents the fracture as a plane. In the quantitative studies of trace length presented below, the complete length of the curved fracture was used.

There are only four faults on pavement 100 and one each on pavements 200 and 300$)$; they are included under the general category of fractures and identified in the comments section in the appendix becaluse we could not determine whether they initially formed as joints or faults and because they are too few to constitute a statistically valid population. On the pavement maps they are identified as faults with arrows indicating the sense of offset (plate 1). No arrow's are shown on fractures where the offset shown on the map is the result of local block-tilting, a minor readjustment due to plant and possibly ice wedging (for example, F25 on pavement 100 ). On all three maps, joints are shown by heavy lines and all other fractures by light lines. The azimuth of fracture strike, dip, dip direction, aperture, length, roughness coefficient, and the pitch of tubes on the face of cooling fractures are keyed to the maps by fracture number in the appendix. Areas of anomalously high infiltration are shown on plate 1 and are 
described below in the section on fracture mineralization and alteration.

\section{FRACTURE CHARACTERISTICS}

\section{Orientation}

Fracture orientation has historically been considered the single most important characteristic. Where a number of fractures share a small range in orientation, they are said to form a set. As will be seen below, not all fractures at Yucca Mountain fall into well-defined sets. Also, not all fractures in a set were necessarily formed during the same event.

The orientation of each fracture was measured at the location where the fractures are numbered on the maps. The azimuth and dip were measured using a Brunton compass. Normally, the azimuth was measured on an exposed portion of the fracture face. In the few places where the rock locally is highly magnetized and deflection of the compass needle can result in incorrect azimuth readings taken when the compass is placed against a fracture, we place the compass against the fracture face and then move it away from the fracture face, parallel to the strike line, to waist level to take the reading.

Repeat measurements indicate that the azimuth readings are reproducible to $2^{\circ}$; dips are reproducible to $1^{\circ}$. The poles to fracture and joint planes and foliation for each of the pavements are plotted on lowerhemisphere equal-area projections on figures 3,4 , and 5. Figure 6 is a compilation of fractures and joints for all three pavements combined. The azimuths, dips, and dip directions are tabulated in the appendix. The fractures range in azimuth from 0 to $360^{\circ}$ with slightly higher concentrations in the southeast and southwest quadrants; dips range from 46 to $90^{\circ}$ with higher concentrations between 80 and $90^{\circ}$. The fractures cannot be grouped into well-defined sets based on orientation. The joints, in contrast, show clustered orientations and two sets can be defined. Joints of one set range in azimuth from 25 to $85^{\circ}$ and in dip from 78 to $90^{\circ}$. Joints of the other set range in azimuth from $27010355^{\circ}$ and in dip from 82 to $90^{\circ}$.

\section{Fracture-Surface Roughness}

Fracture-surface roughness is an important characteristic in hydrologic modeling because it influences the aperture variation as discussed below in the section on aperture, and thereby, the channeling of flow between the fracture walls. Roughness is important in geomechanics, also, for calculating the shear-strength of a fracture (Barton and Choubey, 1977) and closure stiffness under normal loads (Brown and Scholz, 1985). Roughness can also be useful in paleostress analyses as a basis for grouping fractures with a common mechanical and temporal origin, as will be shown below.

Fracture-surface roughness was measured where an unweathered portion could accommodate a 15-cm-long "shape copier." This device (fig. 7) is composed of 148 pins, each about $1 \mathrm{~mm}$ in width. The pins are held in place by frictional force between two rigid plates. The pins are movable so that when the copier is pressed against a fracture surface the pins move to mimic the surface. When the copier is removed from the surface, the pins retain the profile of the fracture roughness. Examples of fracture surface-roughness profiles taken from several fractures are shown on figure $8 A$. The roughness is expressed in the appendix by the roughness coefficient ( $R C)$. The $R C$ was determined by visual comparison to a standard set of profiles of known RC (fig. $8 B$ ), which range (as integer values) from 0 to 20 (Barton and Choubey, 1977). We found that roughness measured in this way and at this scale generally does not vary plus-or-minus one $\mathrm{RC}$ unit with position or orientation on any given fracture surface and therefore only one measurement was made on each fracture. For segmented fractures, $R C$ usually is the same or varies by only one integer value from segment to segment. We do note, that RC can differ by as much as five from segment to segment on segmented fractures (for example, fracture 11.1-11.2 on pavement 200). We offer no explanation of why roughness should vary from one segment to another, especially since the segments were once one continuous fracture.

Roughness frequencies are plotted on figures $9 A$, $B$, and $C$ for each of the pavements. For segmented and highly curved fractures, an RC was measured for each segment or curved section, but the average for the segments or curved portions of a given fracture is plotted on the figures. RC ranges from 1 to 18 and is reproducible to plus-or-minus 2 coefficient values. The RC for the fractures and faults combined ranges from 3 to 18 . The RC for the joints ranges from 1 to 4 . In figure 9 we plot histograms of the frequency of roughness coefficient with bins of 2 coefficient values because that is the reproducibility of our measurement of RC. There is a bimodal distribution one for the joints and one for all other fractures. We fit each of the modes separately with normal distributions. The normal distribution curves are shown on figure 9 . We did not attempt to fit any other type of distribution to the data, but based on visual inspection of the fit of the curves to the histo- 

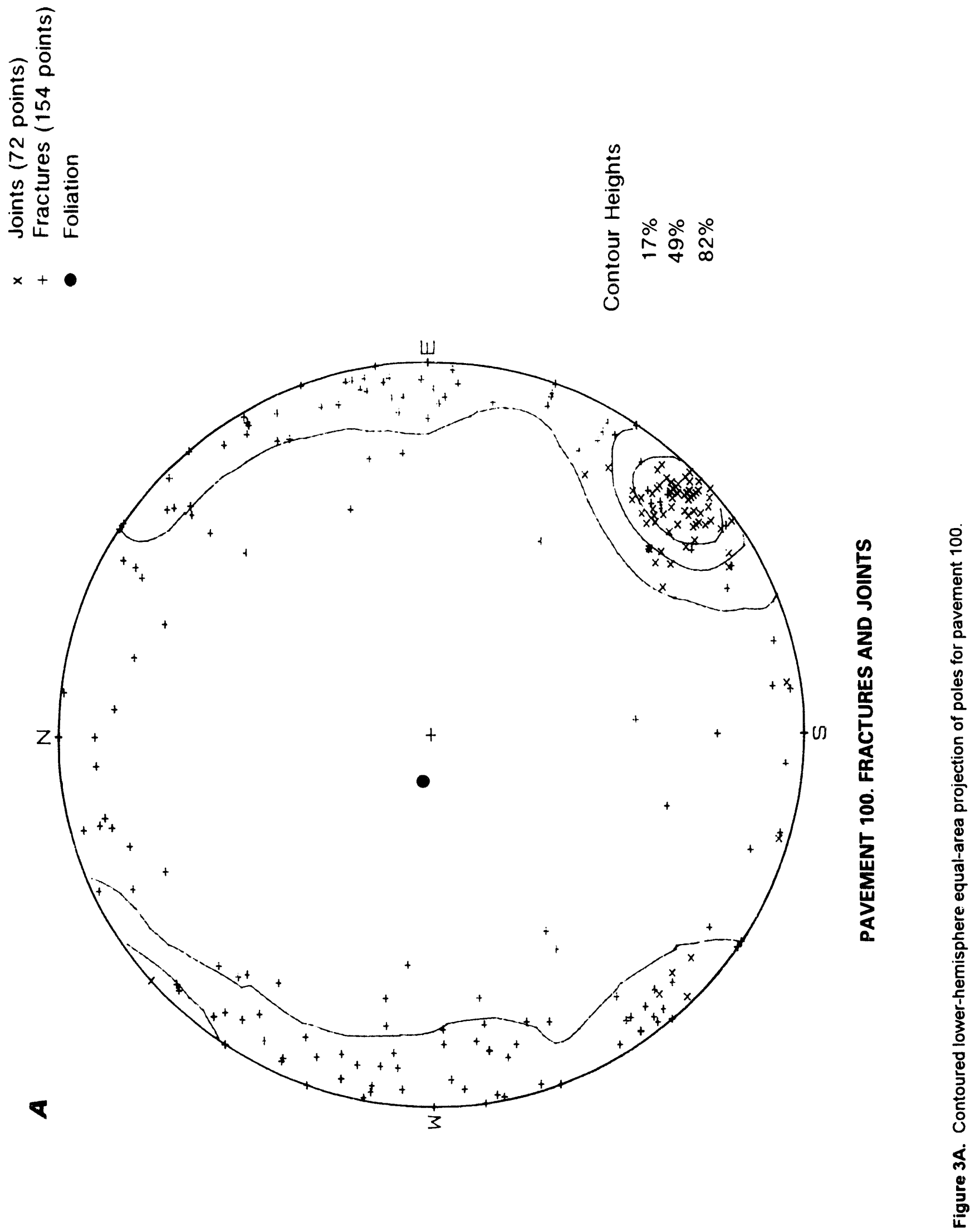

8 Characterizing Fractured Rock for Fluid-flow, Geomechanical, and Paleostress Modeling: Methods and Preliminary Results from Yucca Mountain, Nevada 


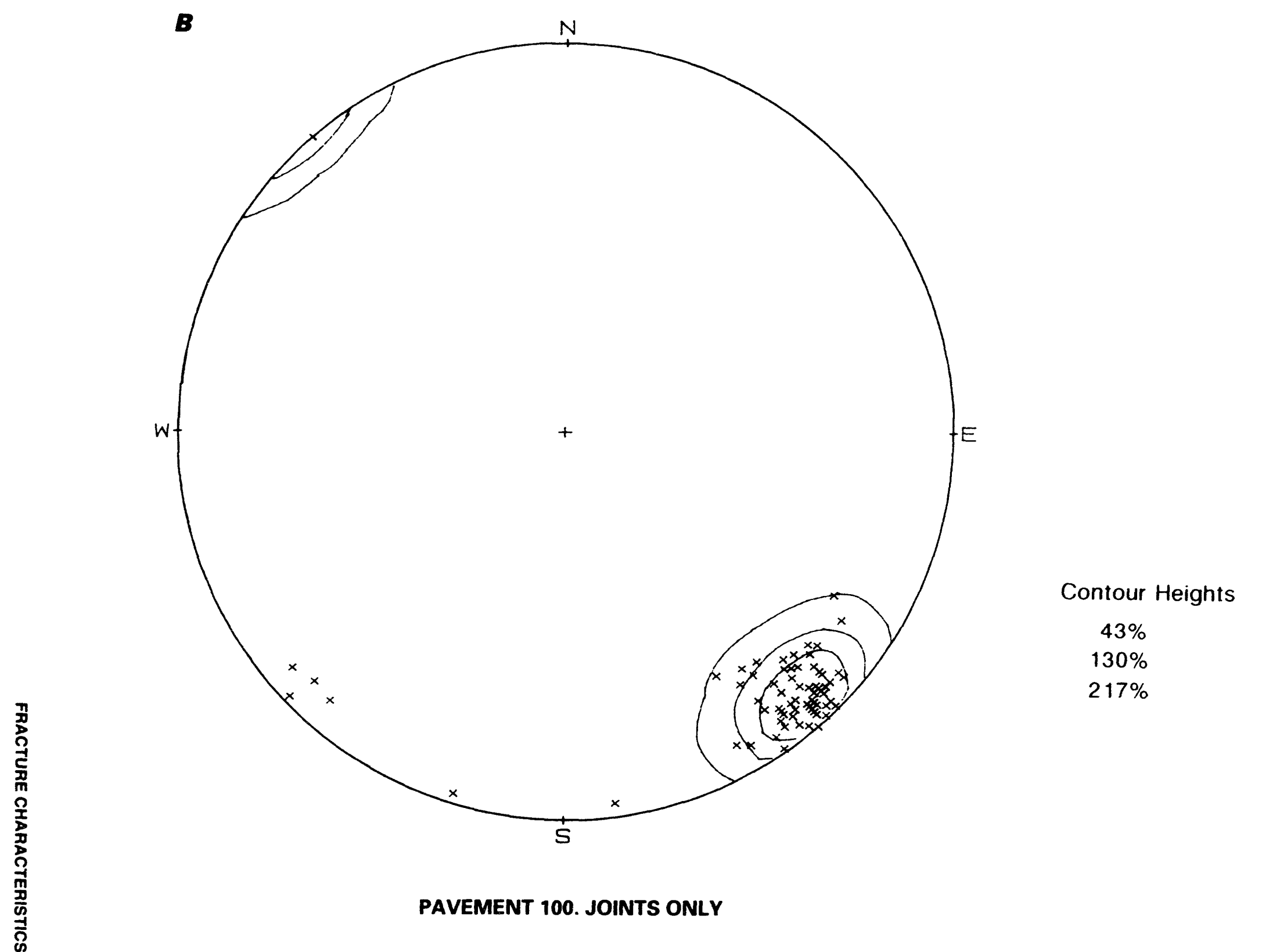

- Figure 3B. Contoured lower-hemisphere equal-area projection of poles for pavement 100-Continued. 


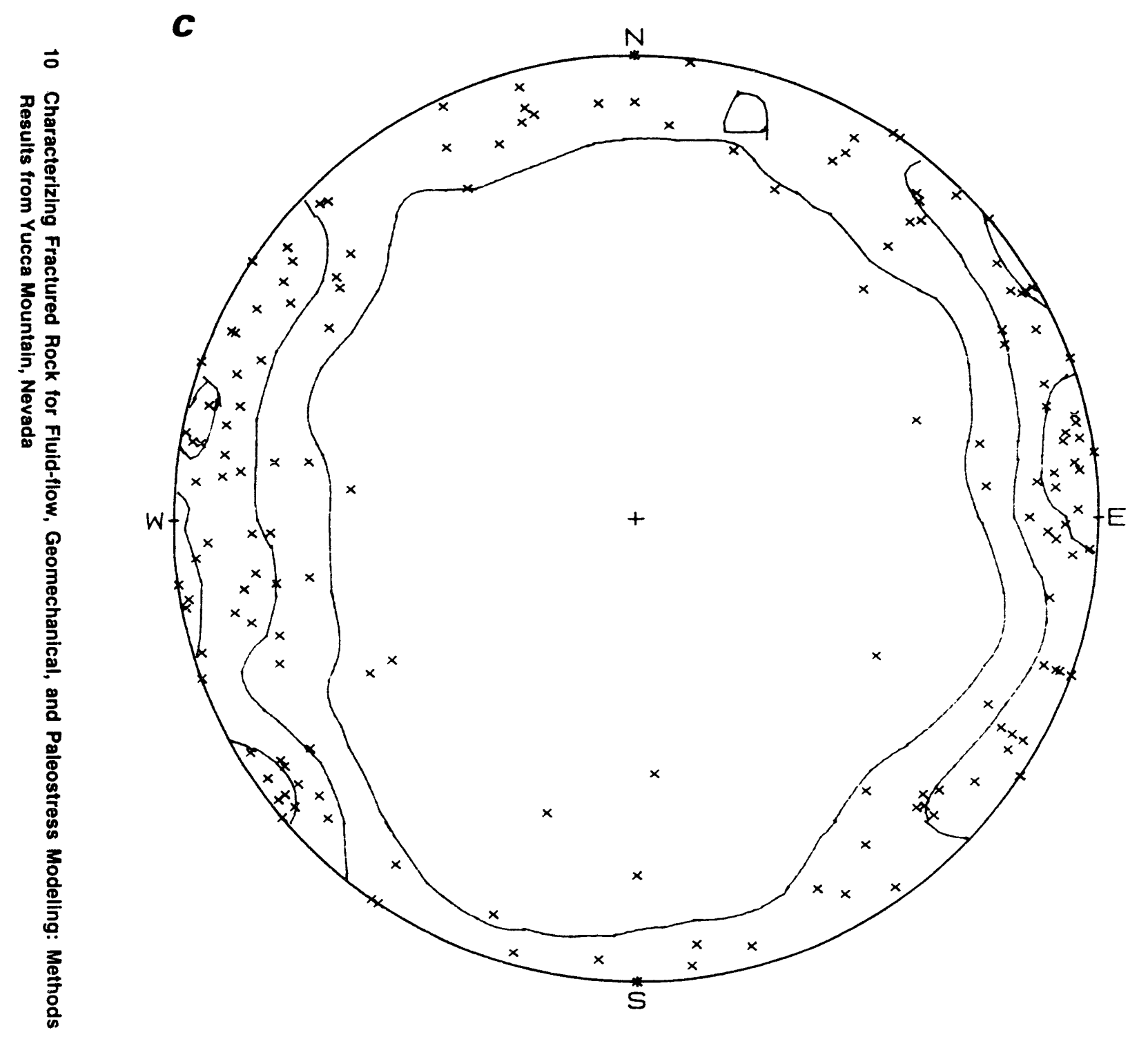

Fractures (154 points)

\section{Contour Heights \\ $8 \%$ \\ $27 \%$ \\ $44 \%$}

\section{PAVEMENT 100. FRACTURES ONLY}

Figure 3. Contoured lower-hemisphere equal-area projection of poles for pavement 100--Continued. 

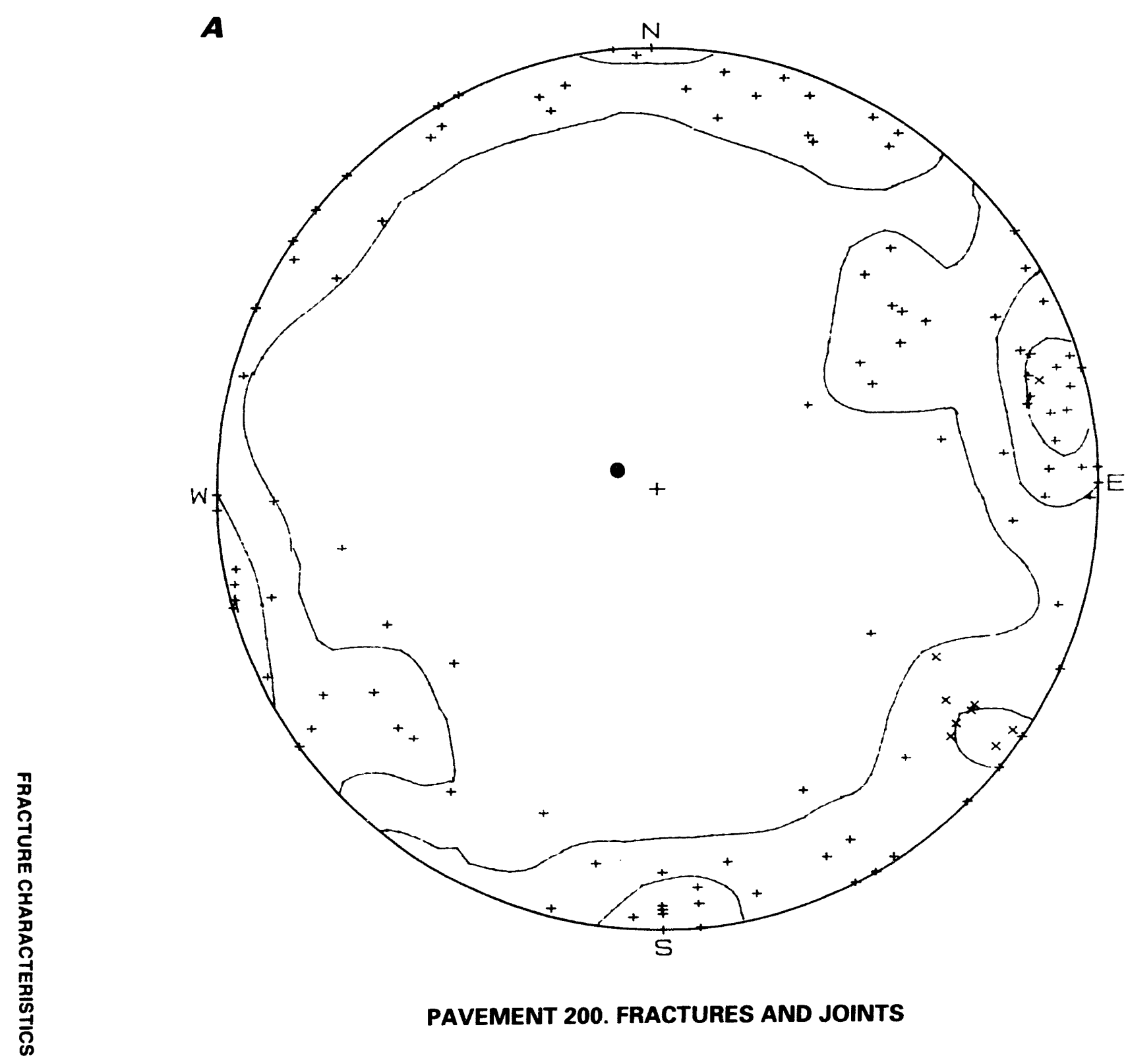

$\times \quad$ Joints (9 points)

$+\quad$ Fractures (95 points)

- Foliation

\section{PAVEMENT 200. FRACTURES AND JOINTS}

Contour Heights

$11 \%$

$33 \%$

$56 \%$

$=\quad$ Figure 4. Contoured lower-hemisphere equal-area projection of poles for pavement 200. 


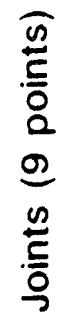
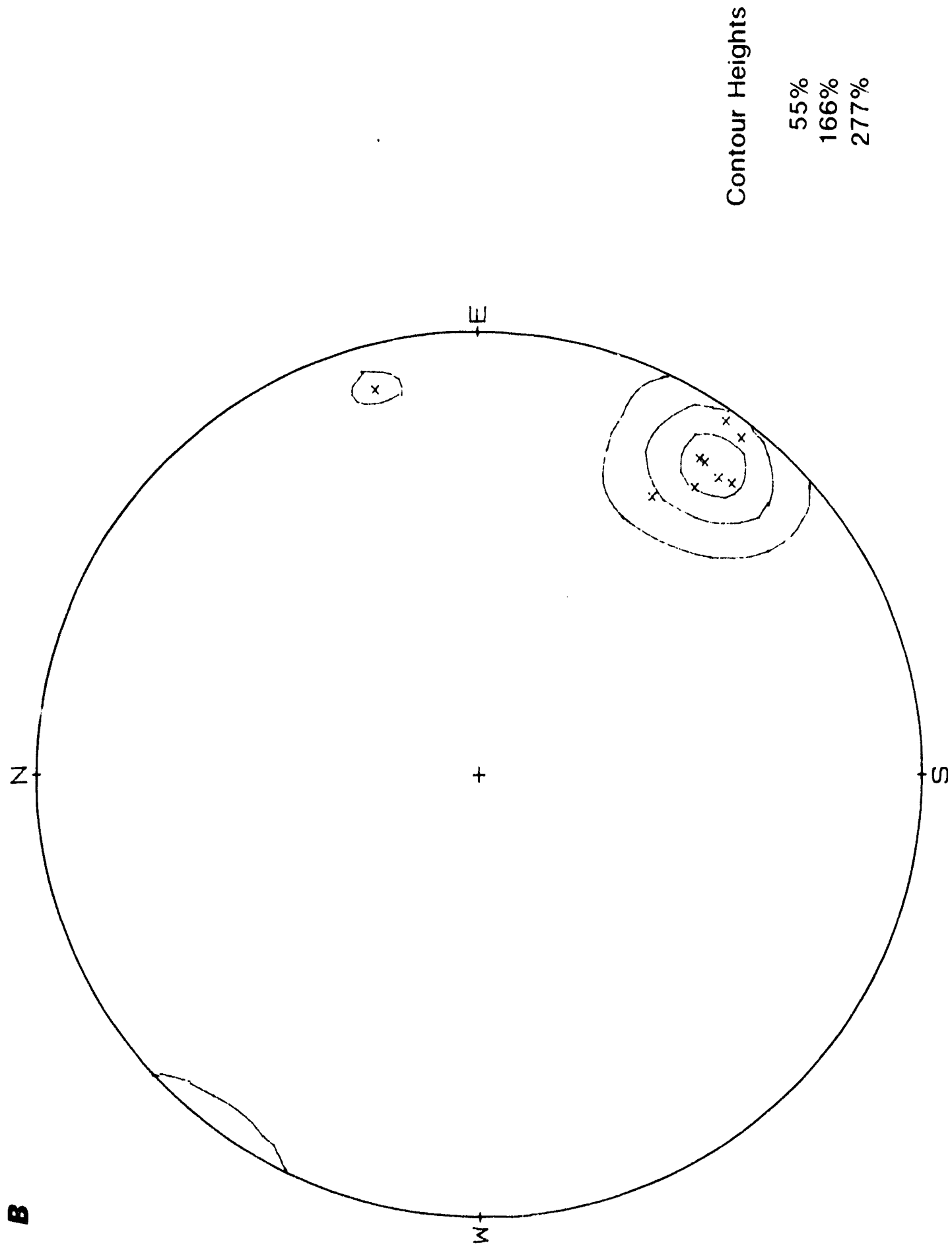

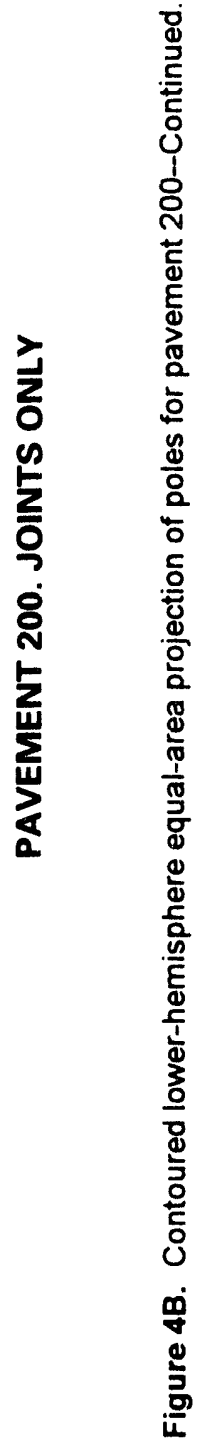

12 Characterizing Fractured Rock for Fluid-flow, Geomechanical, and Paieostress Modeling: Methods and Preliminary Results from Yucca Mountain, Nevada 


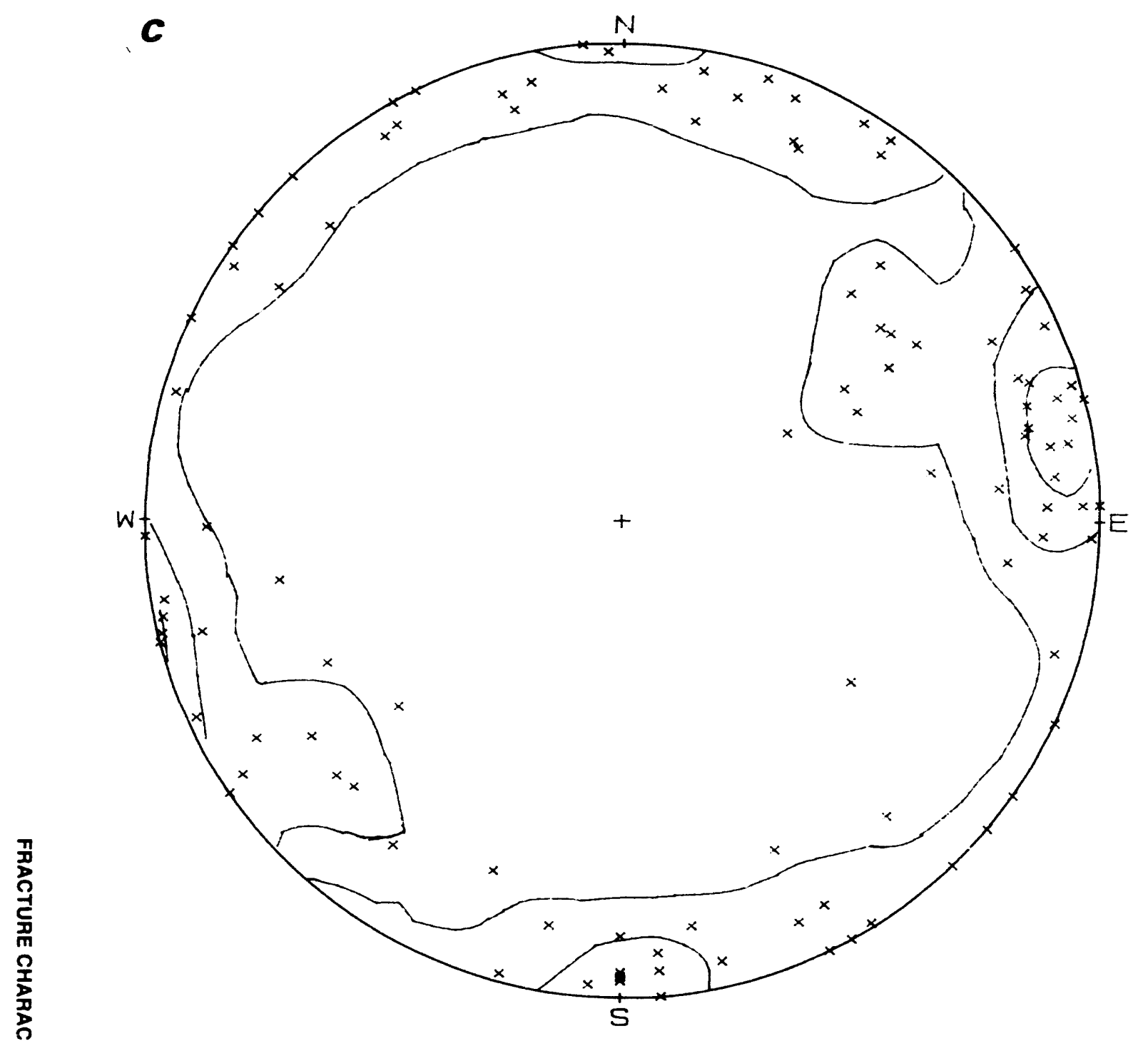

Fractures (96 points)

Contour Heights

$12 \%$

$35 \%$

$58 \%$

PAVEMENT 200. FRACTURES ONLY

Figure 4C. Contoured lower-hemisphere equal-area projection of poles for pavement 200-Continued. 


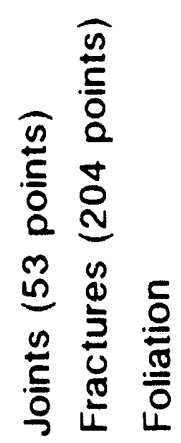
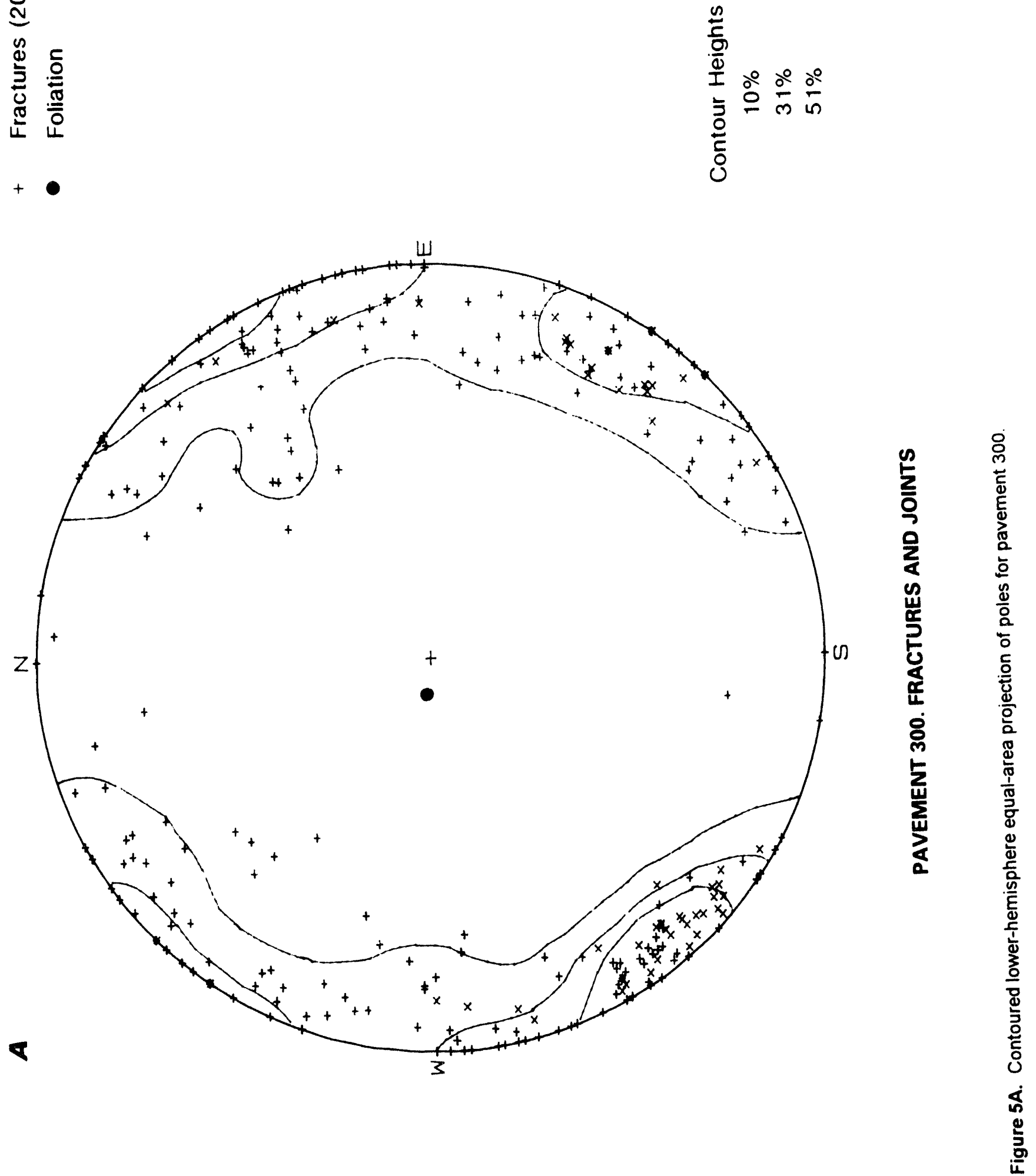

14 Characterizing Fractured Rock for Fluid-flow, Geomechanical, and Paleostress Modeling: Methods and Preliminary Results from Yucca Mountain, Nevada 


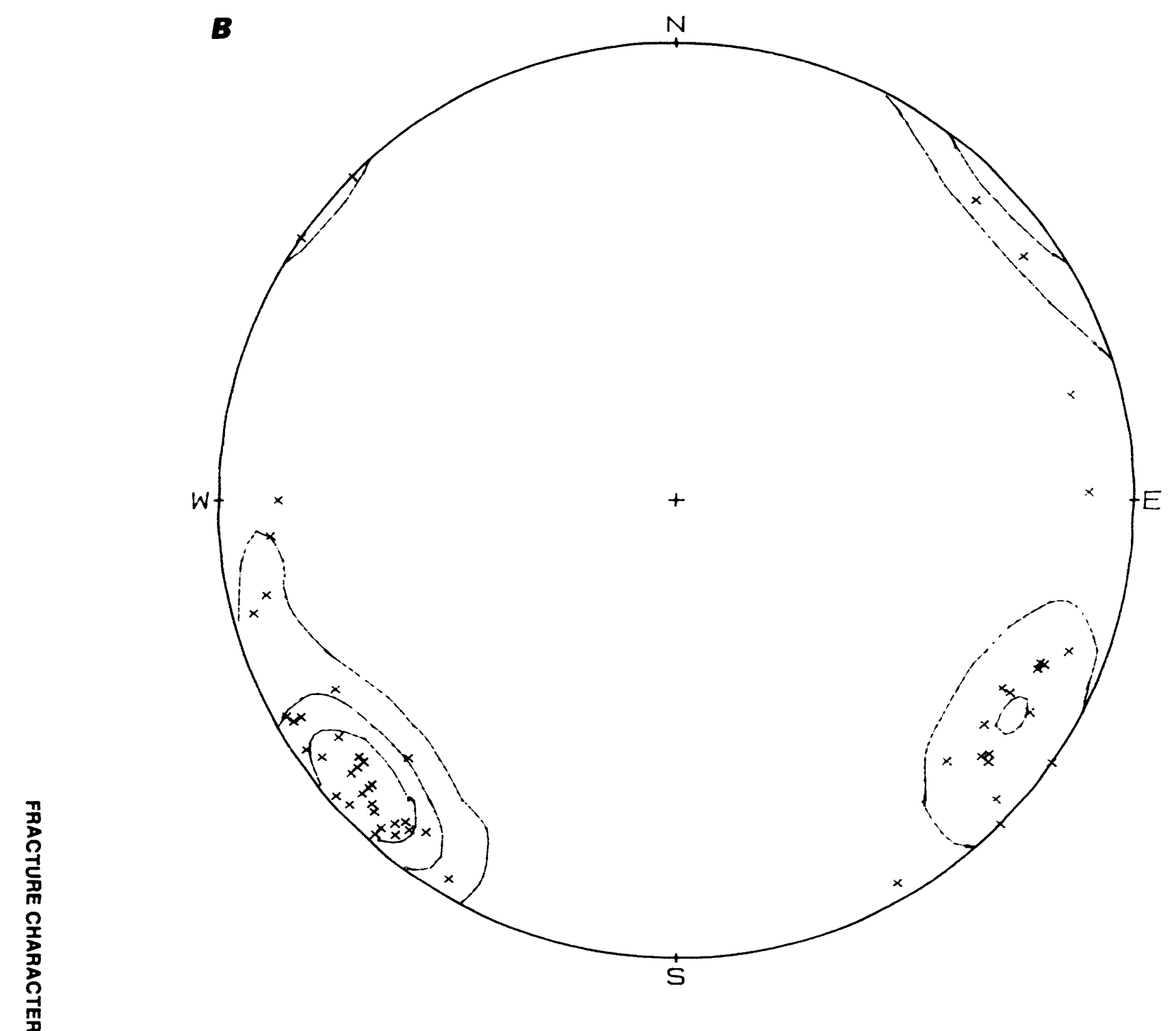

Joints (53 points)

PAVEMENT 300. JOINTS ONLY

Figure 5B. Contoured lower-hemisphere equal-area projection of poles for pavement 300--Continued. 
Fractures (204 points)

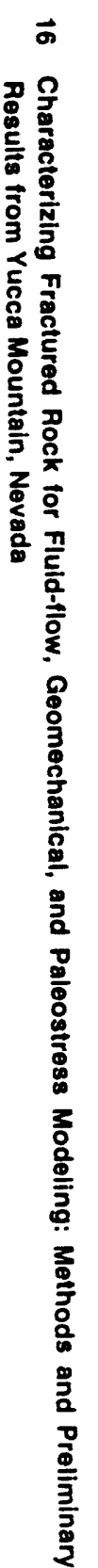

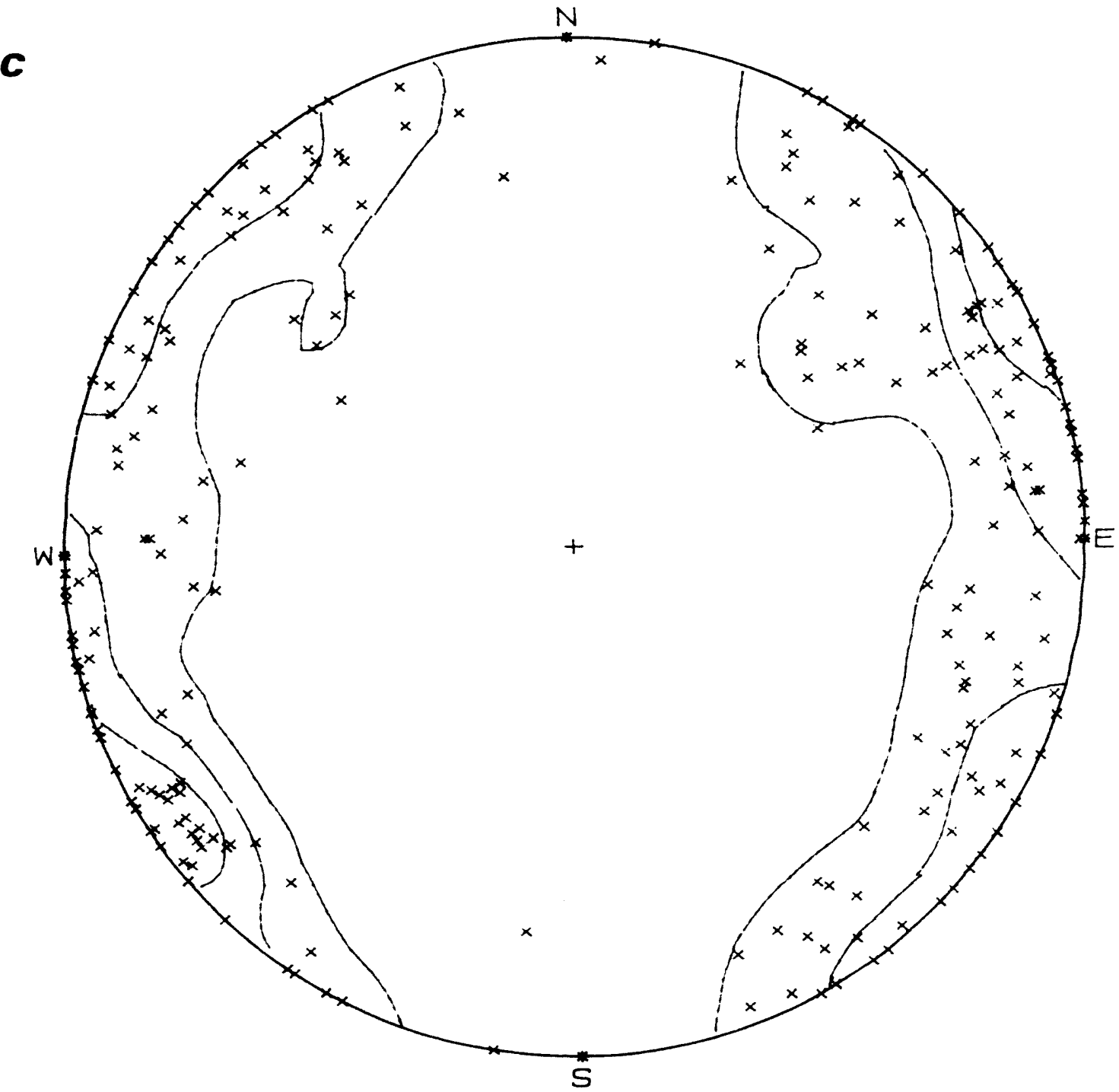

\section{Contour Heights}

$9 \%$

$28 \%$

$48 \%$

\section{PAVEMENT 300. FRACTURES ONLY}

Figure 5C. Contoured lower-hemisphere equal-area projection of poles fpr pavement 300-Continued 


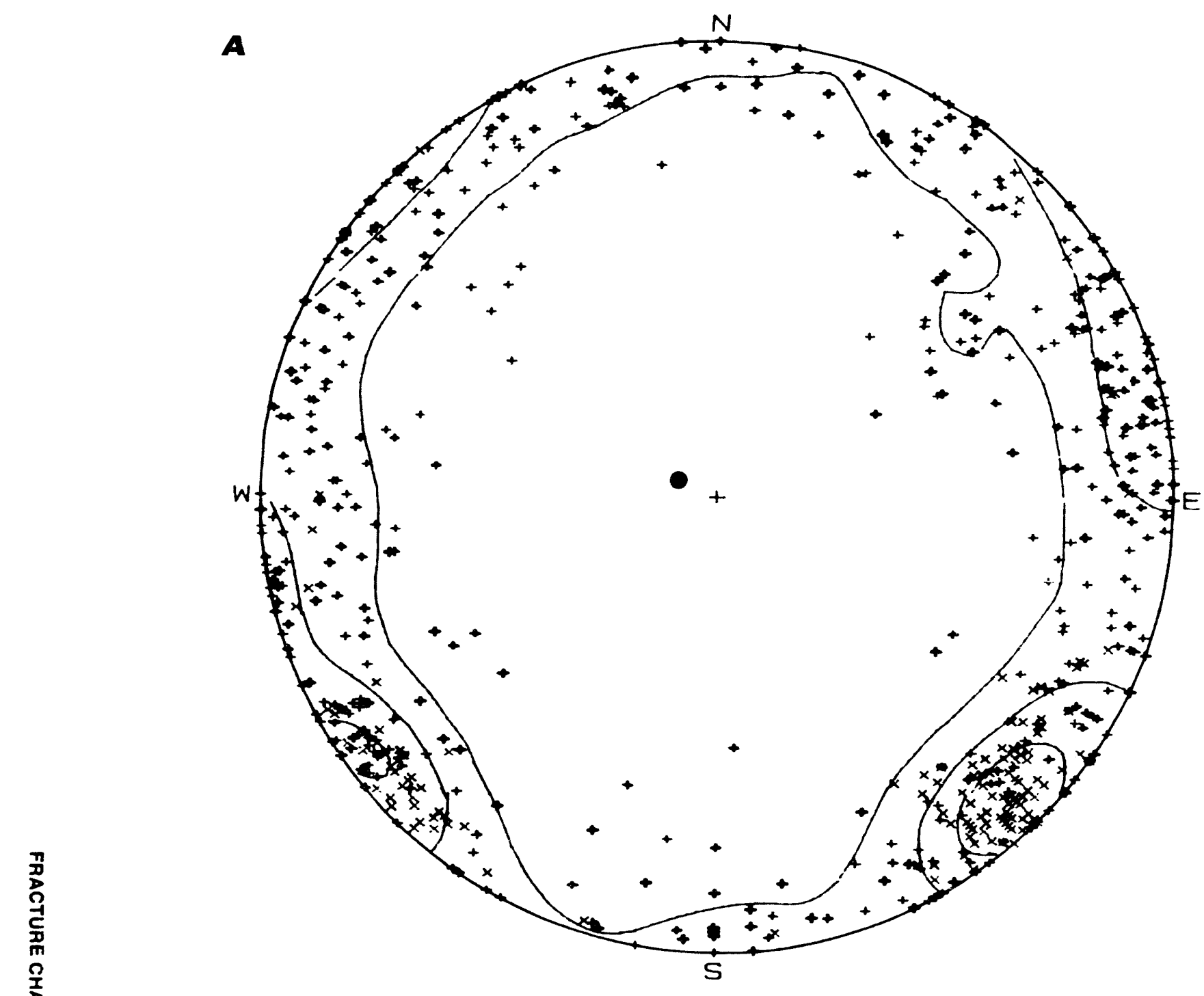

$\times \quad$ Joints (134 points)

+ Fractures (454 points)

- Foliation

588 Points total

PAVEMENT 100, 200, 300. FRACTURES AND JOINTS

Figure 6A. Contoured lower-hemisphere equal-area projection of poles for pavements 100,200 , and 300 combined. 


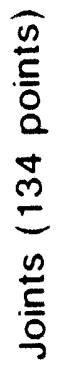
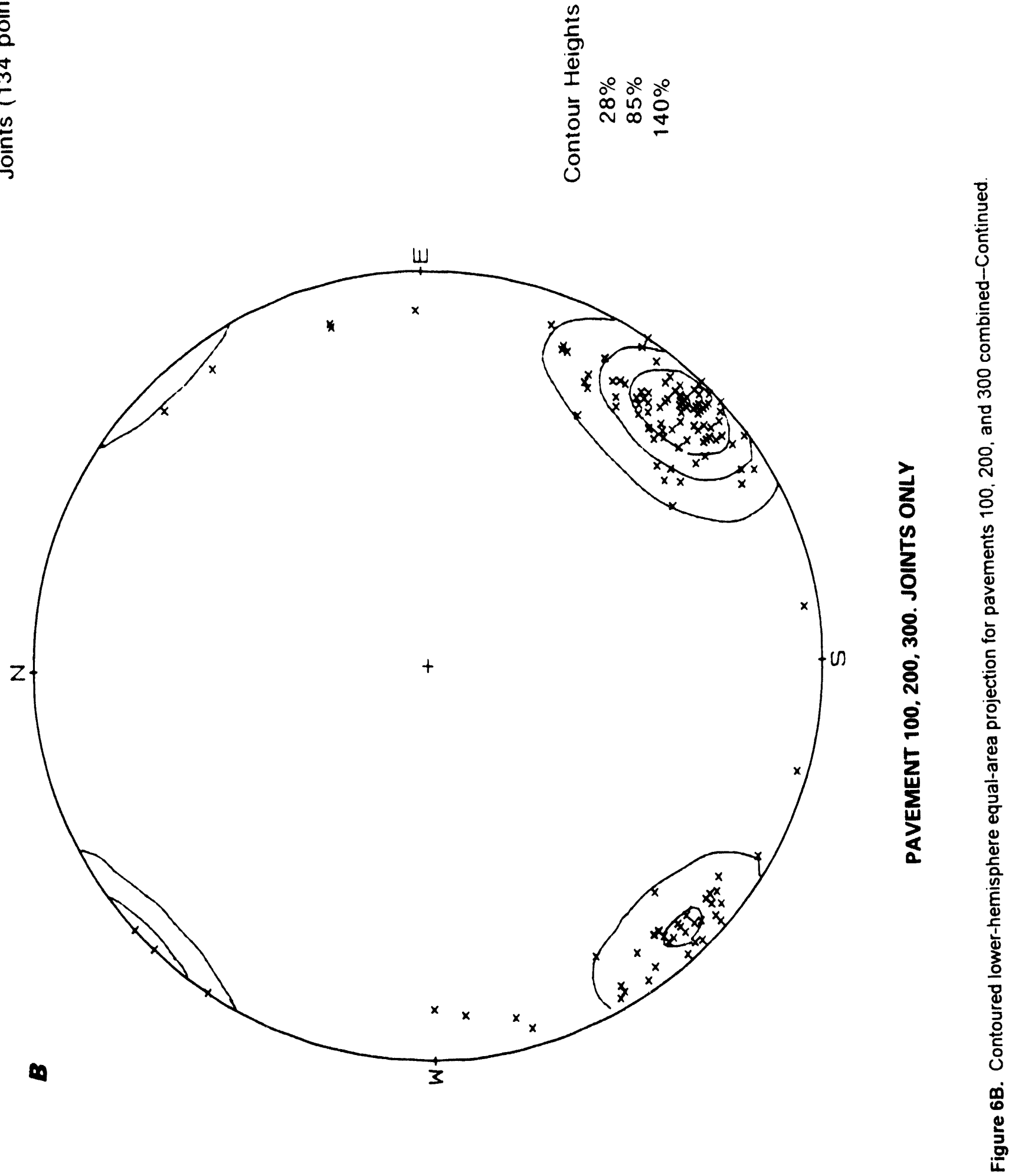

18 Characterizing Fractured Rock for Fluid-flow, Geomechanical, and Paleostress Modeling: Methods and Proliminary Results from Yucca Mountain, Novada 


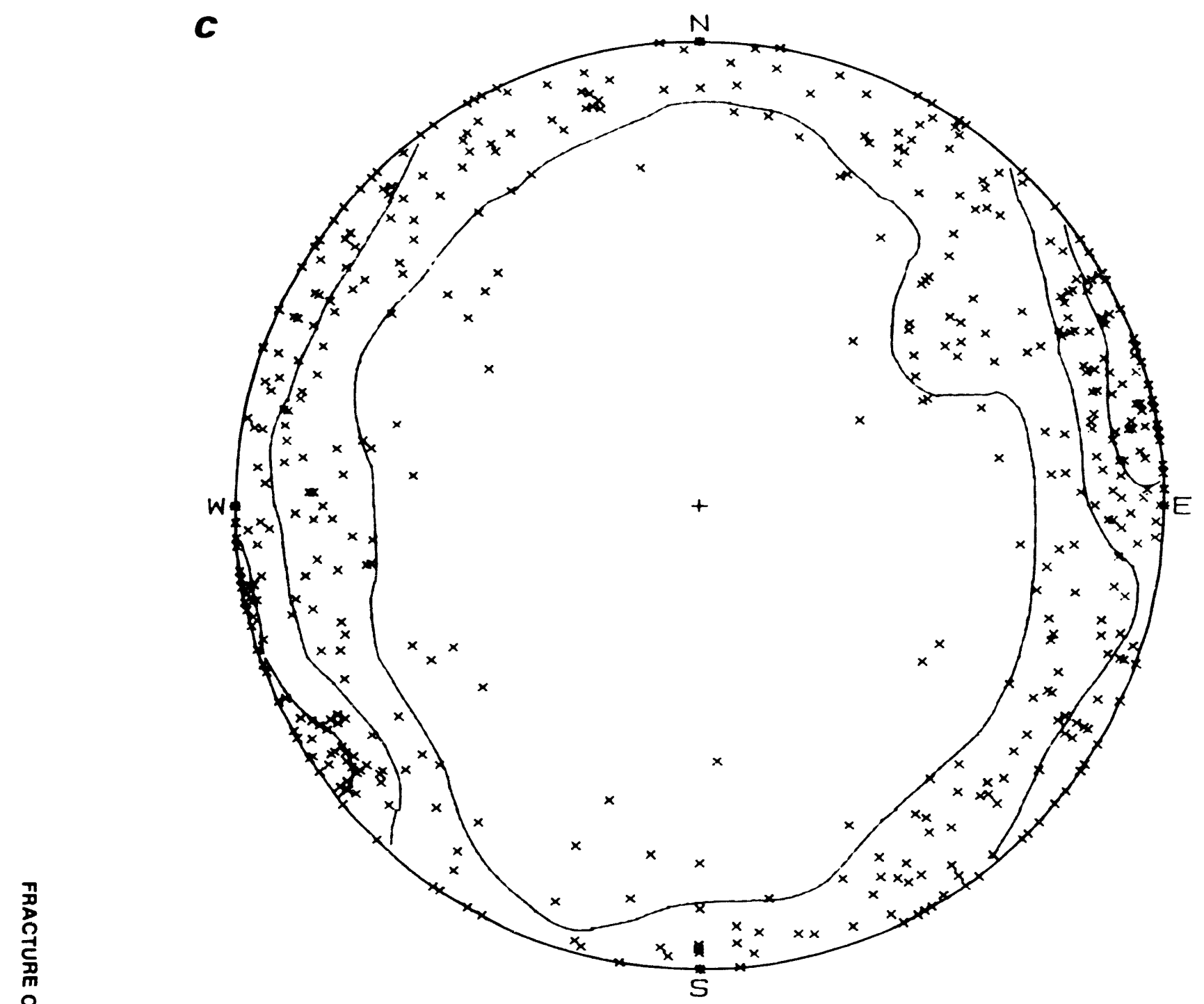

Fractures (454 points)

Contour Heights

$9 \%$

$28 \%$

$46 \%$

\section{PAVEMENT 100, 200, 300. FRACTURES ONLY}

Figure 6C. Contoured lower-hemisphere equal-area projection of poles for pavements 100,200 and 300 combined-Continued 


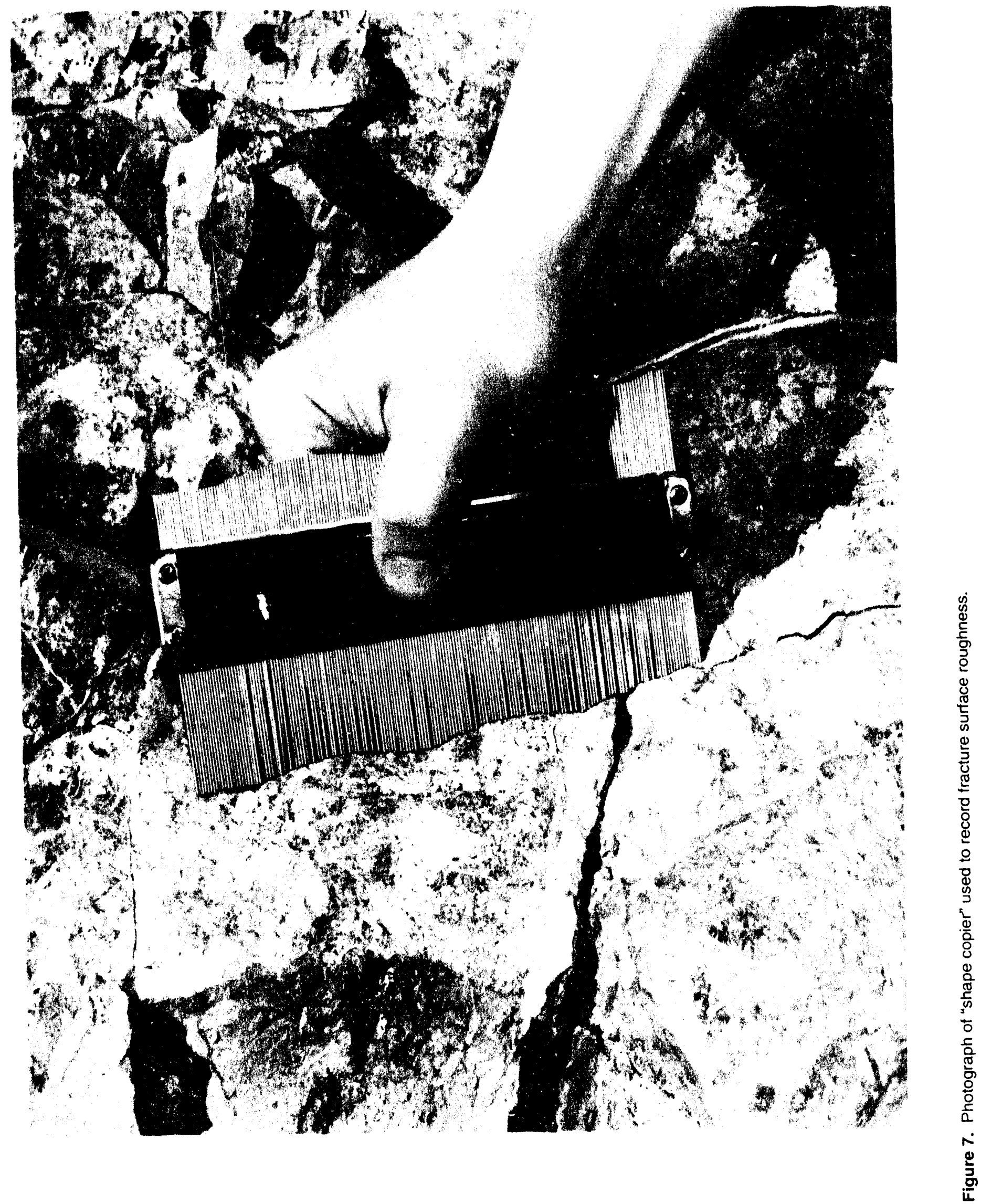

20 Characterizing Fractured Rock for Fluid-flow, Geomechanical, and Paleostress Modeling: Methods and Preliminary Results from Yucca Mountain, Nevada 


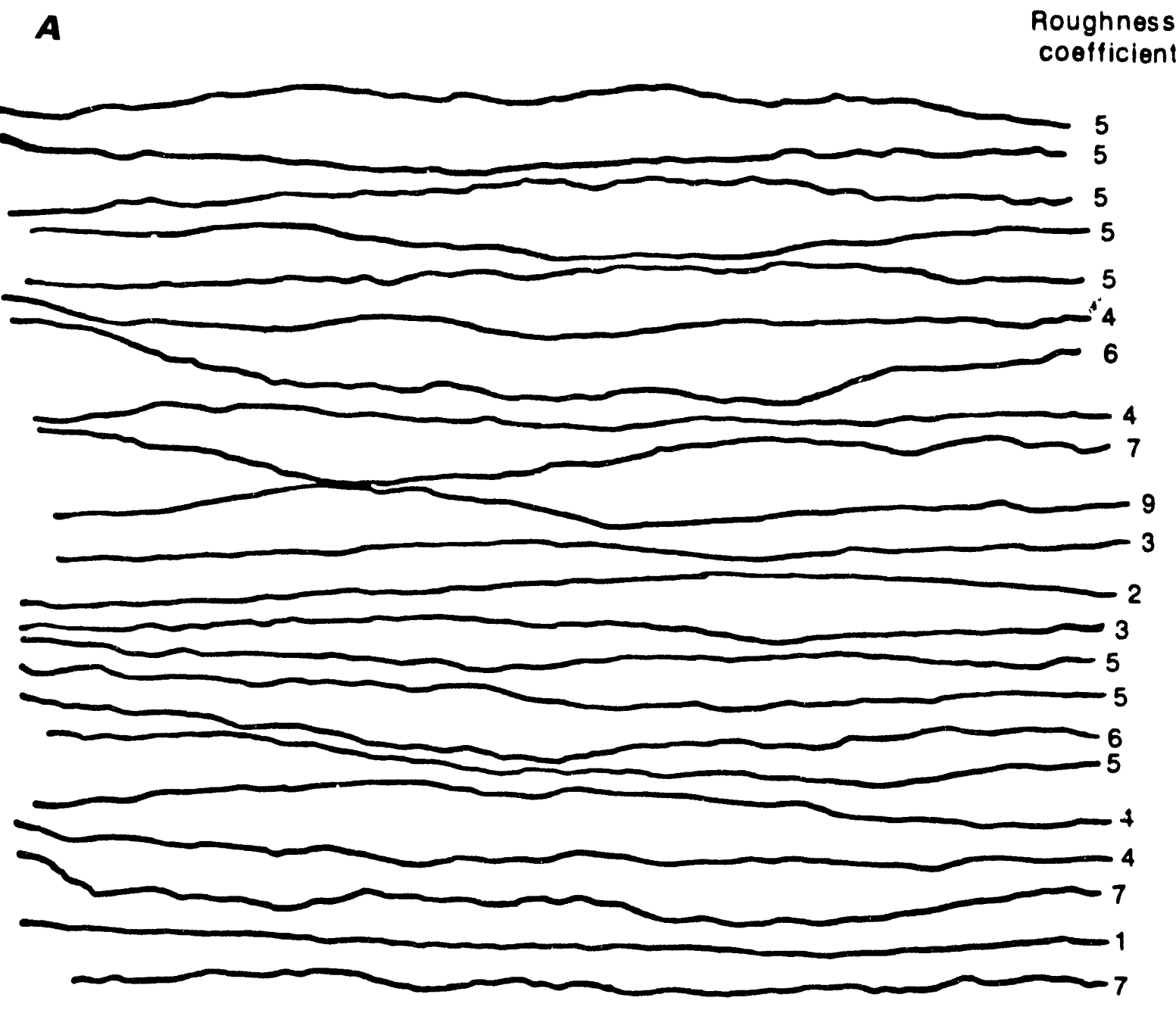

Figure 8A. Profiles of fracture -surface roughness. 


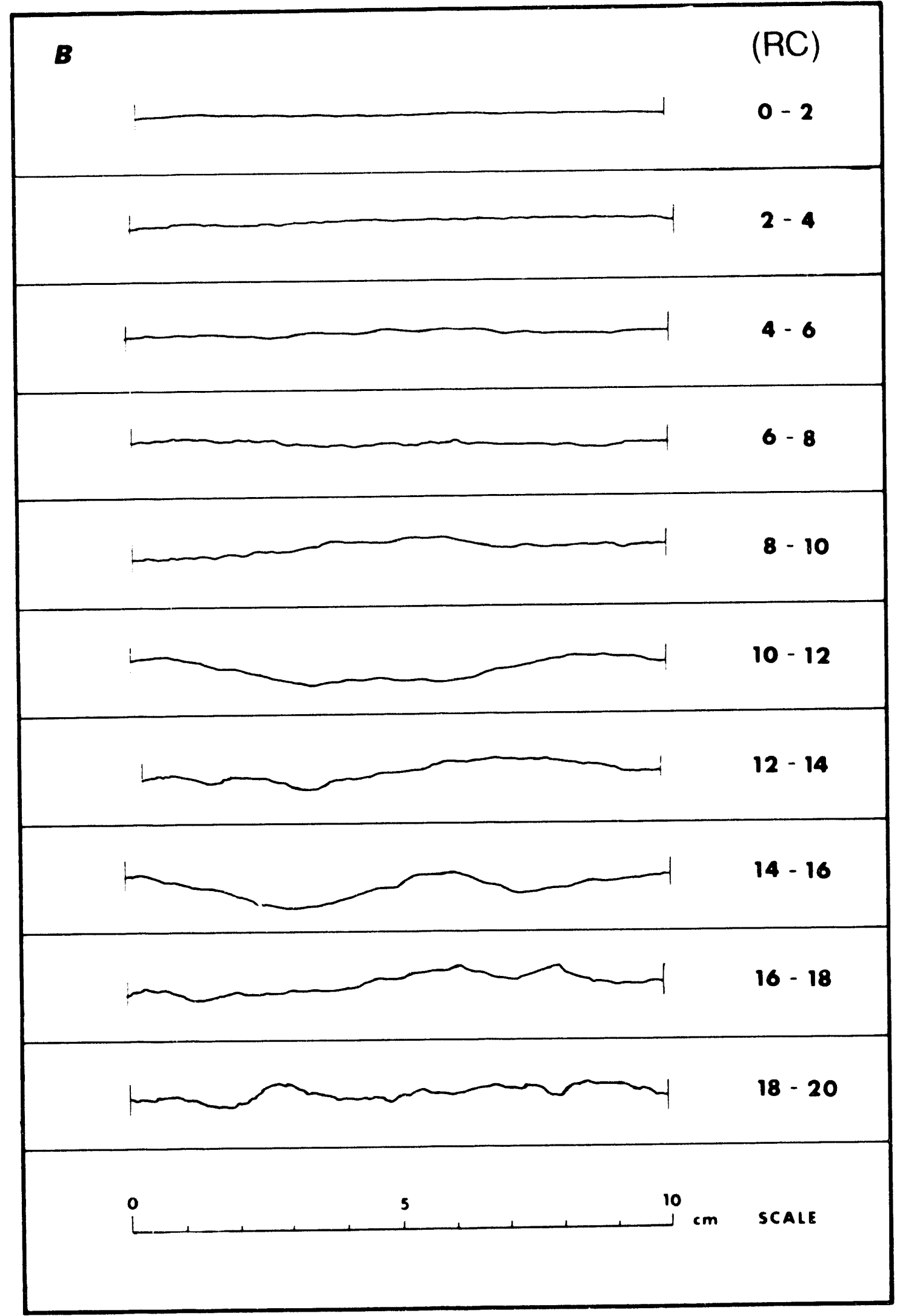

Figure 8B. Profiles of fracture-surface roughness (From Barton and Choubey, 1977, p. 19). 


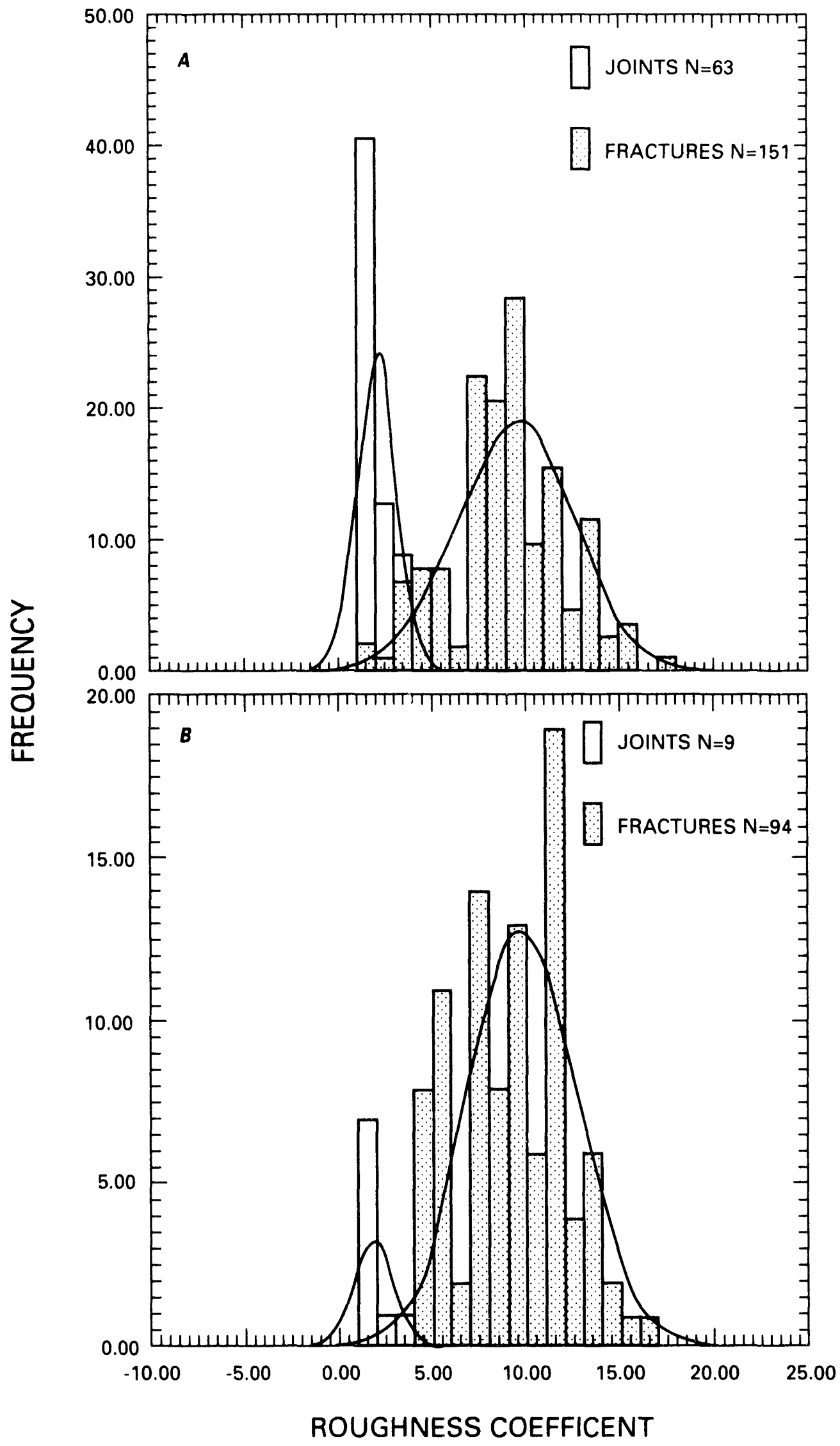

Figure 9A \& 9B. Frequency histogram of roughness coefficient for joints and fractures fitted with normal curves A. Pavement 100; B. Pavement 200; C. Pavement 300. 


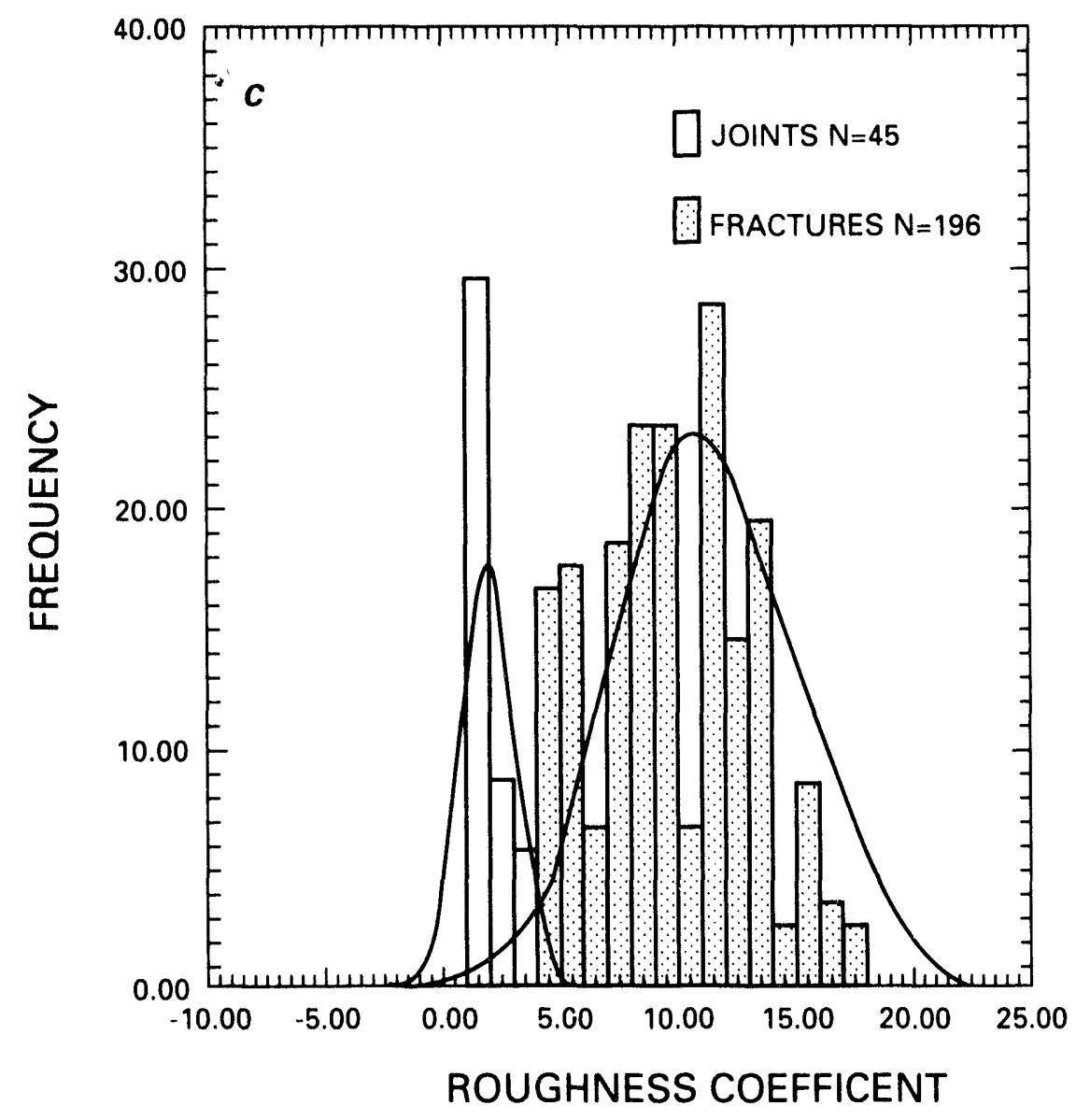

Firgure 9C. Frequency histogram of roughness coefficient for joints and fractures fitted with normal curves. A. Pavement 100; B. Pavement 200; C. Pavement 300--Continued. 
grams, we suggest that $\mathrm{RC}$ for both the fractures and joints is normally distributed. Joints are less well fit, probably because their $\mathrm{RC}$ values are adjacent to a forbidden range $(\mathrm{RC}<0)$ and tail off toward higher values which produces asymmetric distributions. The histograms of frequency distributions (figure 9) are fit by normal curves of the form:

$$
y=\left((1 / s)(2 \pi)^{-1 / 2}\right) e^{-(x-m)^{2} / 2 s}
$$

where $y$ is the frequency, $x$ is the roughness coefficient, $m$ is the mean, and $s$ is the standard deviation. The values of the mean and standard deviation are given in table 1. The narrow range of $\mathrm{RC}$ for the joints suggests that the joints share a common mode and time of origin that is distinctly different from the fractures, as will be confirmed independently below.

Table 1. Normal-curve constants for fracture roughness coefficient

$$
\begin{gathered}
y=\left((1 / s)(2 \pi)^{-1 / 2}\right) e^{-(x-m)^{2} / 2 s} \\
(y=\text { frequency, } x=\text { roughness coefficient, } m=\text { mean; } \\
s=\text { standard deviation })
\end{gathered}
$$

\begin{tabular}{lcccc}
\hline \multirow{2}{*}{ Pavement } & \multicolumn{2}{c}{ Joints } & \multicolumn{2}{c}{ Fractures } \\
\cline { 2 - 5 } & $\mathbf{m}$ & $\mathbf{s}$ & $\mathbf{m}$ & $\mathbf{s}$ \\
\hline 100 & 2.19 & 1.03 & 9.61 & 3.13 \\
200 & 1.78 & 1.09 & 9.74 & 2.96 \\
300 & 2.18 & 1.01 & 10.33 & 3.39 \\
$100,200,300$ & 2.16 & 1.03 & 9.96 & 3.22 \\
combined & & & & \\
\hline
\end{tabular}

\section{Fracture Aperture}

Aperture is extremely important in evaluating the flow characteristics of a fracture. For smoothwalled fractures, the volumetric flow rate is a function of the aperture cubed. For rough fractures, Cook (1992) reports that the volumetric flow rate in laboratory specimens of rock to be a function of the aperture to a power greater than three but less than six. The functional dependence of flow rate on aperture for rough fractures is a topic of much study at present, as is the functional relation between hydraulic aperture and mechanical aperture. Hydraulic aperture is a derived quantity, calculated from hydrologic tests performed either in the field of in the laboratory. We report here on the mechanical aperture measured on gaping fractures.
We recognize that the removal of overlying rock and exposure to surface weathering has affected the apertures. The exact values are affected, but not the form of the aperture distribution; we see the same form independent of hill slope, or location of the pavement as shown below. In contrast, apertures measured underground are affected by stress redistribution around the walls of boreholes and excavations, and by blasting. It is not possible to measure mechanical apertures that are unaffected, either at the surface or underground. Our view is that an imperfect measure of aperture is preferable to no measure.

A representative aperture was determined by visual inspection at places where weathering was minimal and mineralization absent. Small apertures were measured with an automotive feeler gage and larger ones with a ruler. Aperture frequencies, normalized by dividing the number in each interval by the total number measured on the pavement, are plotted on figure 10 for each pavement. We attempted to fit exponential, logarithmic, log-normal, and power-law functions to the histograms of aperture frequency. The histograms are best fit by a power law of the form $y=a x^{b}$, where $y$ is the frequency, $x$ is the aperture, and $a$ and $b$ are constants. The values of the constants and the coefficient of determination (goodness of fit) are given in table 2. At length scales less than the 0.2 meter lower cutoff in our data, we observe a dramatic increase in the number of fractures with decreasing size scale, down to the scale of micro-fractures. This observation further supports our conclusion that a power-law is the most appropriate fit to the aperture data.

Anisotropy in aperture for the network is of interest because it contributes to anisotropy in the hydraulic conductivity of the fracture network and in the bulk geomechanical properties. The apertures have opened in response to local and regional tectonic and topographic stresses that caused and subsequently reactivated the fractures. Apertures represent only the normal component of opening displacements.

In order to study aperture anisotropy as a function of orientation, we constructed a rose diagram to represent a two-dimensional summation of aperture as a function of the azimuth of fracture opening (fig. 11). The length of each petal in the diagram is the sum of apertures open in the direction of that $10^{\circ}$ interval normalized by dividing by the number of fractures that contributed to that interval. The symmetry of the diagram is an artifact of considering all fractures to strike between 0 and $180^{\circ}$ to first construct the right side of the diagram and then making the left side of the diagram symmetrical. The directions of slope of the pavement surfaces and the axes of ridges on which the pavements are located are also plotted on figure 11. 


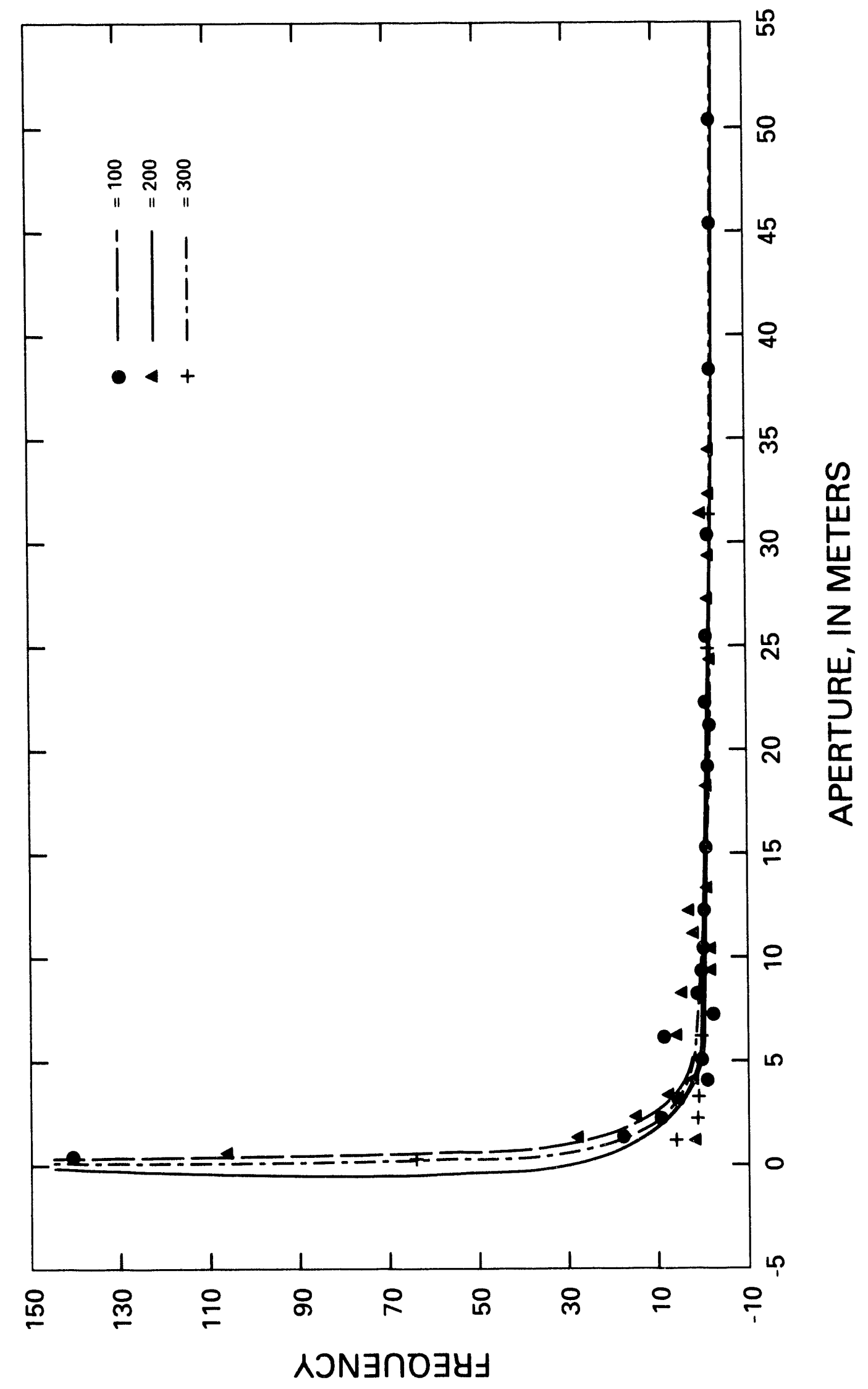

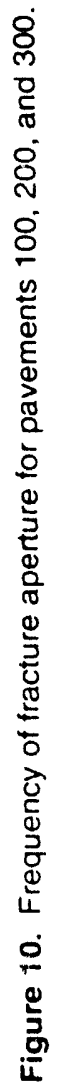




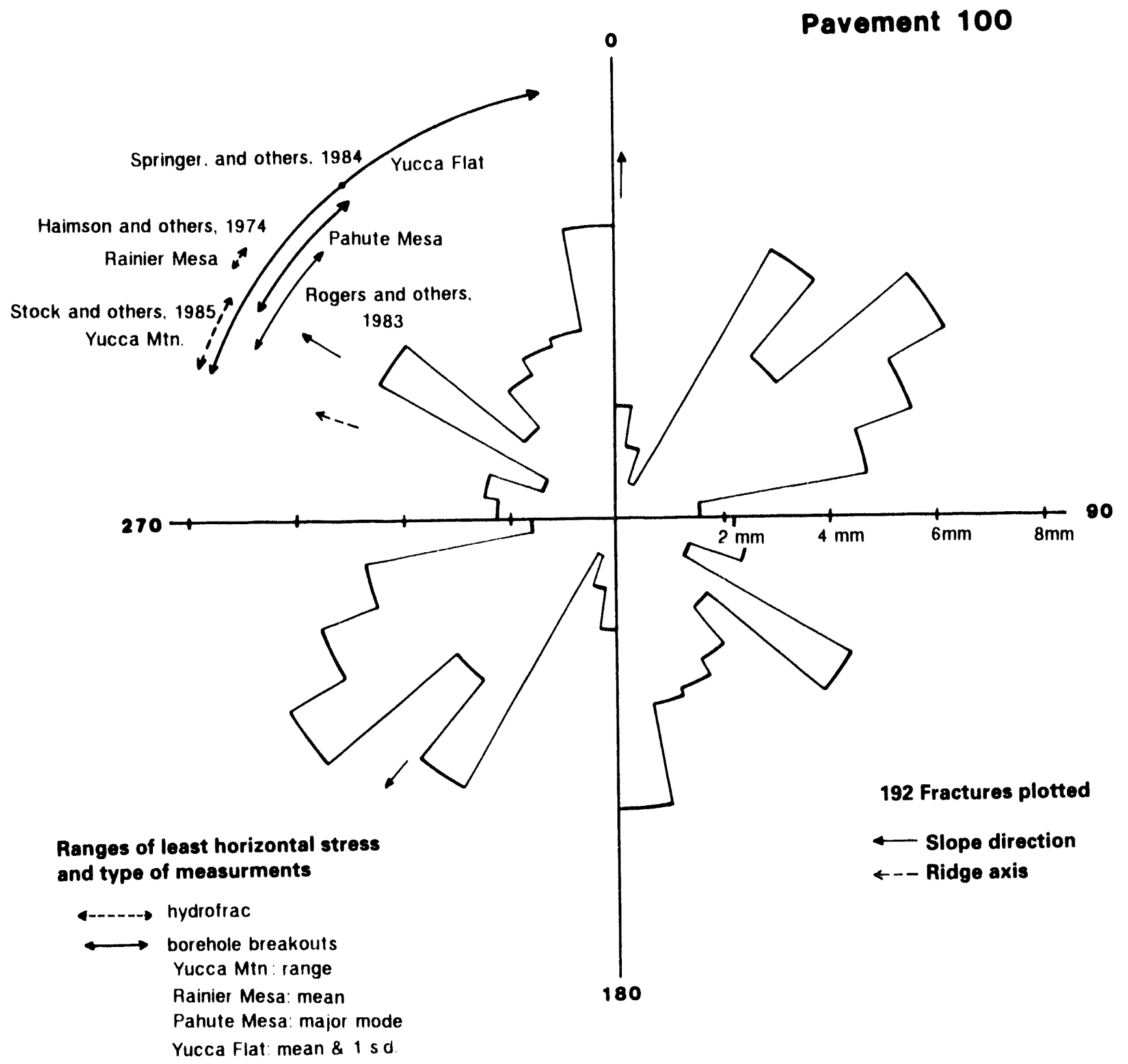

Figure 11A. Rose diagrams of aperture as a function of the azimuth of fracture opening A. Pavement 100; B. Pavement 200; C. Pavement 300 
Pavement 200

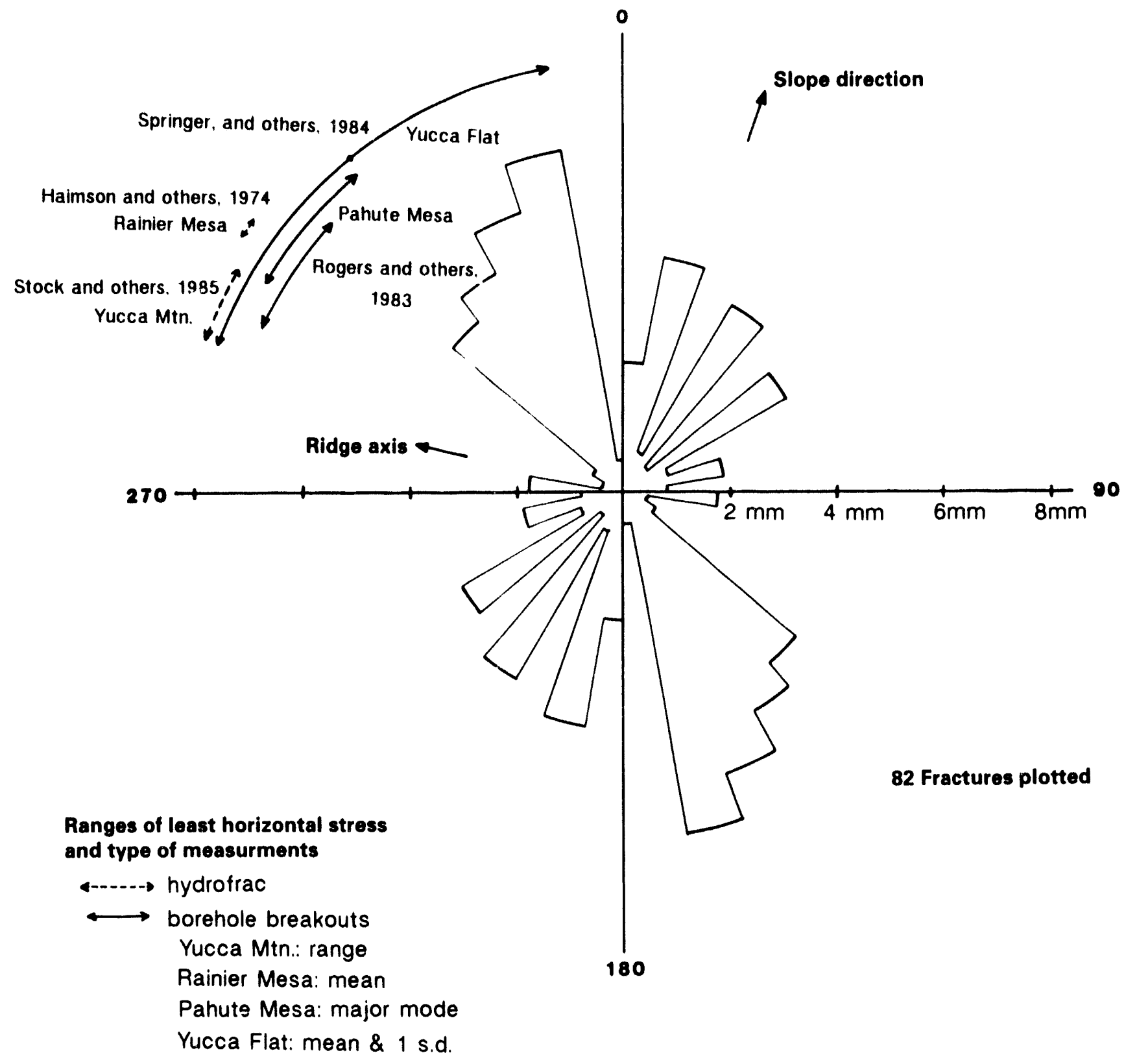

Fiyure 11B. Rose diagrams of aperture as a function of the azimuth of fracture opening.

A. Pavement 100; B. Pavement 200; C. Pavement 300--Continued. 


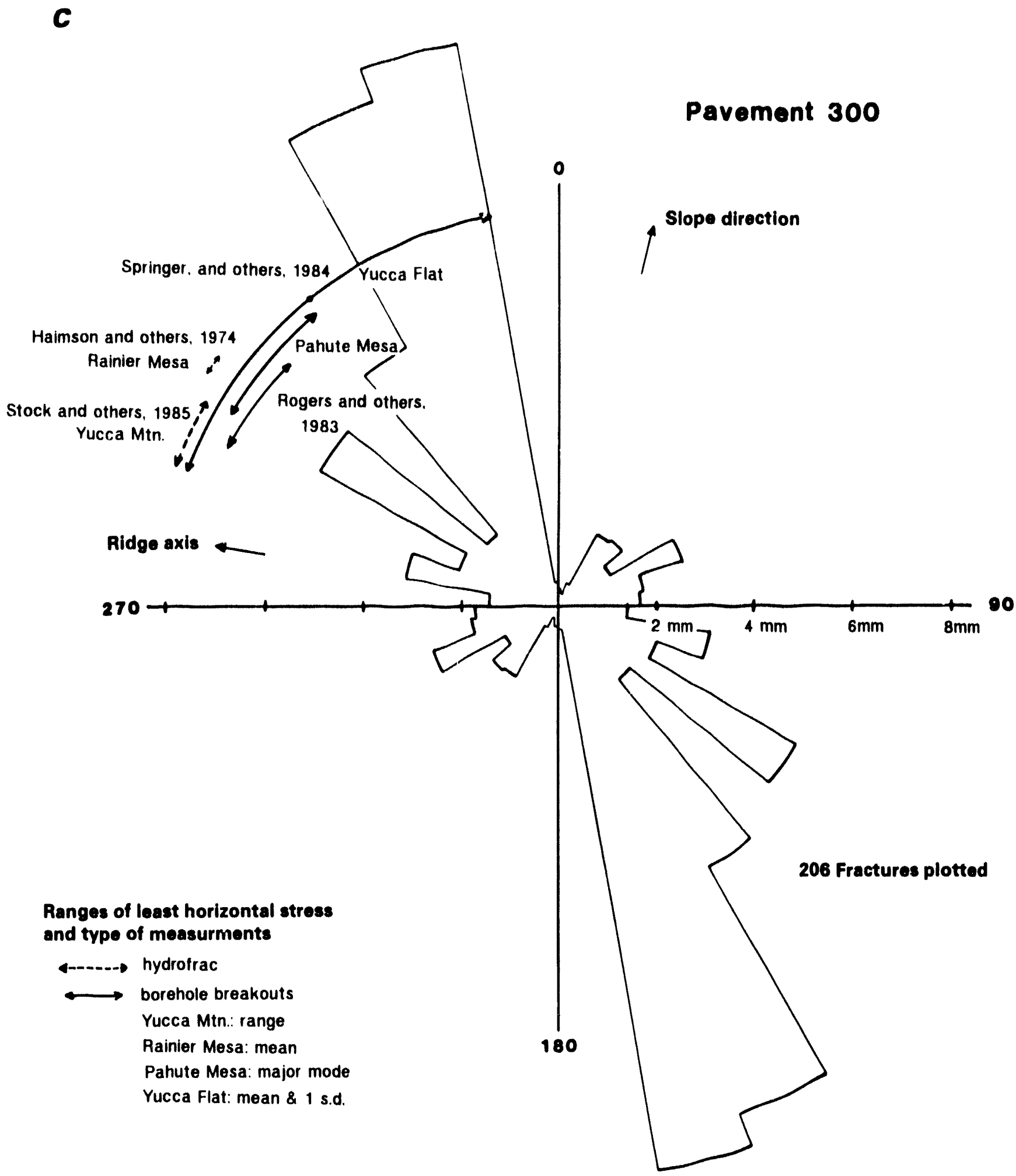

Figure 11C. Rose diagrams of aperture as a function of the azimuth of fracture opening.

A. Pavement 100; B. Pavement 200; C. Pavement 300--Continued. 
The slopes of pavement surfaces are less than twelve degrees and vary less than five degrees on any given pavement.

The azimuth of the least horizontal stress measured at or near Yucca Mountain by hydrofracture (Haimson and others, 1974: Stock and others, 1985) and borehole breakouts (Springer and others, 1984) are also plotted in figure 11. These methods indicate as much as $60^{\circ}$ degrees of variation in the direction of the least horizontal stress, but it is always oriented in a northwest-southeast direction. This matches an analysis of earthquake focal mechanisms which sample deeper stratigraphic levels in the region (Rogers and others, 1983), and which resolves the least horizontal principal stress to be between 290 and $310^{\circ}$.

Inspection of figure 11 indicates anisotropy in fracture apertures, but interpretation is difficult. Azimuths of maximum opening on pavements 200 and 300 are northwest-southeast and fall within the range of the in-situ least horizontal stress, and therefore, we suggest that there may be a direct relation between the two. For pavement 100 (fig. 11A), the greatest opening direction is northeast-southwest which coincides with the direction of overall slope of the pavement surface, and therefore, we suggest that there may be a direct relation between the Iwo.

\section{Fracture-Trace Length}

Fracture-trace lengths were measured on plate 1 . and the frequencies, normalized by dividing the number in each interval by the total number measured on the pavement, are plotted on figure 12 for each of the three pavements. The plots include the exposed lengths of fractures whose traces extend beyond the edges of the pavement. Because these are distributions

Table 2. Power-law constants for trace length and aperture

$$
y=a x^{b}
$$

$\left(r^{2}=\right.$ coefficient of determination)

( $y=$ frequency; $x=$ aperture $a, b=$ constants)

\begin{tabular}{lrrrrrr}
\hline \multirow{2}{*}{ Pavement } & \multicolumn{3}{c}{ Trace length } & \multicolumn{3}{c}{ Aperture } \\
\cline { 2 - 7 } & \multicolumn{1}{c}{$\mathbf{a}$} & \multicolumn{1}{c}{$\mathrm{b}$} & \multicolumn{1}{c}{$\mathbf{r}^{2}$} & $\mathrm{a}$ & \multicolumn{1}{c}{$\mathrm{b}$} & \multicolumn{1}{c}{$\mathbf{r}^{2}$} \\
\hline 100 & 10.12 & -1.17 & 0.78 & 15.78 & -1.10 & 0.79 \\
200 & 9.05 & -0.84 & .73 & 14.99 & -0.87 & .74 \\
300 & 11.21 & -1.32 & .82 & 11.35 & -0.99 & .76 \\
100,200, & 12.17 & -1.47 & .84 & 15.36 & -1.26 & .82 \\
300 & & & & & & \\
combined & & & & & & \\
\hline
\end{tabular}

with long tails, truncation affects the exact values, but not the overall form of the distribution. The lower end of the distribution is truncated because no trate lengths less than $0.20 \mathrm{~m}$ were mapped. The upper end is truncated because many trace lengths exceed the dimensions of the pavements. As with aperture, we attempted to fit exponential, logarithmic, log-normal, and power-law functions to the trace-length frequency histograms. The histograms are best fit by a power law of the form $y=a x^{b}$, where $y$ is the frequency, $x$ is the trace length, and $a$ and $b$ are constants. The values of the constants and the coefficient of determination (goodness of fit) are shown in table 2. Qualitative observation of fractures less than our lower cutoff of 0.2 meters reveals greatly increasing numbers of fractures with decreasing size, this further supports a power-law distribution of fracture-trace lengths.

In order to test the validity of including fractures whose traces extend beyond the pavement boundary. we also fit the four types of functions to only those fractures completely contained within the pavement boundary. Again, the data for pavements 100, 200, and 300 were best fitted by a power law with the values of the power b within 9,5, and 3 percent, respectively, of the values shown on table 2 . Thus, we feel confident in including the traces of fractures that extend beyond the pavement boundary in statistical analyses of fracture trace length.

Segall and Pollard (1983) mapped fracture traces at two pavement sites in the Mount Givens granodiorite in the central Sierra Nevada Mountains of California. They also fit the trace-length frequency distributions with a power law. In order to compare uur results with theirs, we have fitted their data following the method described above. For their data b equals -0.66 and -1.46 . Our values of $b$ range from -0.84 to -1.33 (table 2). In contrast to our study of networks composed of fractures of many generations and orientations, only one uniformly oriented generation is present at their sites. Also, the lower end of their distribution is truncated at 2 meters; ours continues down another order of magnitude to 0.2 meters. The same power-law form and similar values for the exponent $b$ for both studies suggest that trace-length frequency may be controlled by geometric aspects of the fracture process that are independent of rock type, age, and tectonic history.

Qualitative examination of fracture traces down to I centimeter in length at the pavement sites revealed very high numbers of small fractures that are not visible to an observer from a standing position. Conversely, we have been able to follow the traces of some of the fractures for tens of meters beyond the boundaries of the pavements. These qualitative observations 


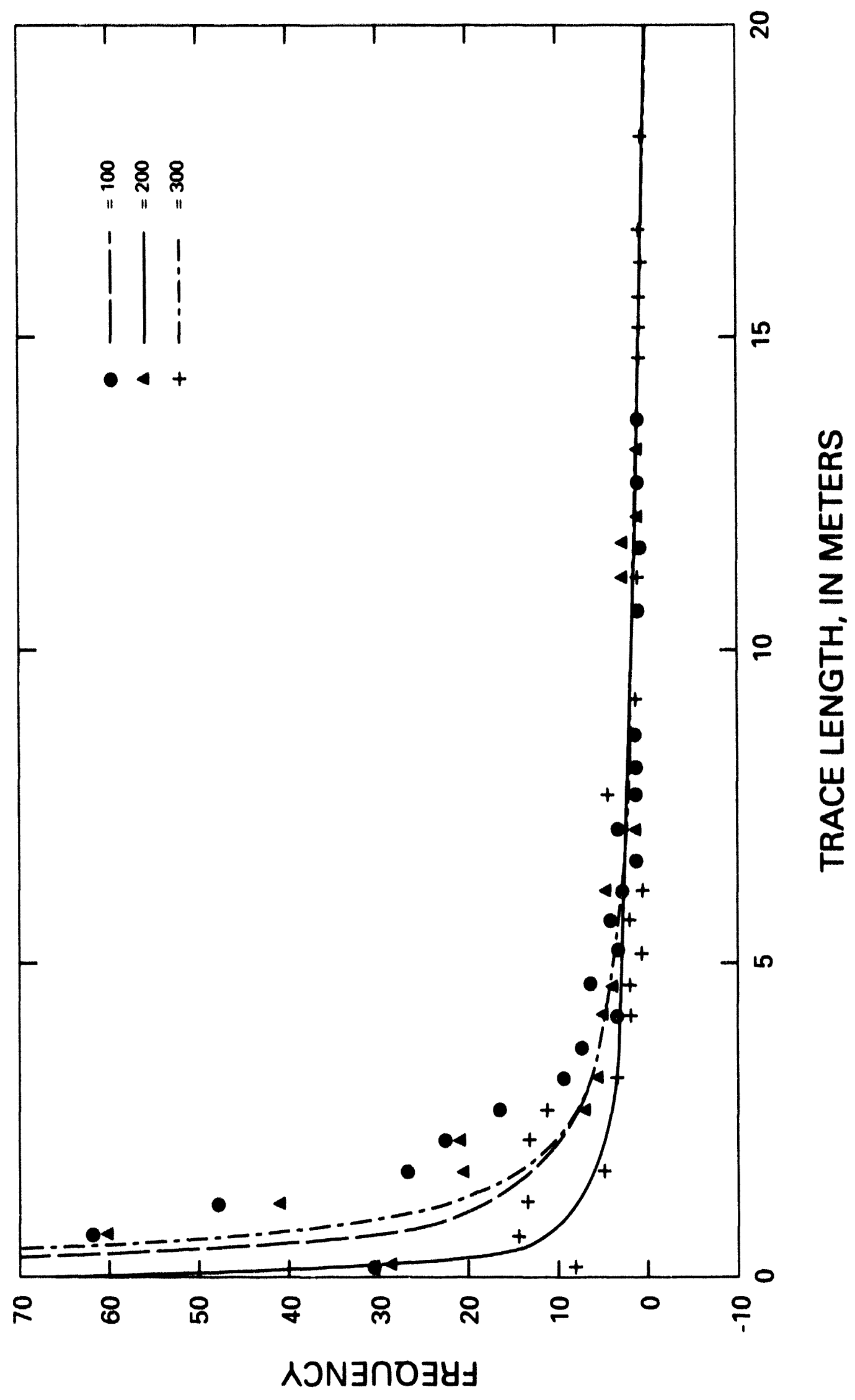

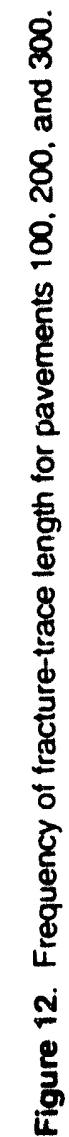


suggest to us that extrapolation along the power-law curves to smaller and longer traces is reasonable.

We find no correlation between fracture-trace length and aperture (fig. 13). A linear correlation has been reported for completely isolated nonintersecting calcite filled fractures in two-dimensional vertical exposures (Verbeek and Grout, 1989). A correlation should not be expected for networks of intersecting open fractures, because intersecting open fractures bound blocks that rotate and slide to readjust in response to subsequent loading and unloading.

\section{Fracture-Length Density}

The density of iracturing is a parameter used in generating synthetic fracture patterns for hydrologic and geomechanical modeling. An areal fracture density can be expressed in terms of the sum of fracturetrace lengths measured on plate 1 , per unit area of pavement surface. The fracture densities for pavements 100,200 , and 300 are $2.35,1.40$, and $2.35 \mathrm{~m}^{-1}$, respectively.

Some areas of fracturing on the pavements are so intense that it is not possible to show each fracture on the maps. These areas are identified on plate 1 by stippling; short line segments indicate the representative azimuth of the fractures within each area. Some of these areas are bounded by one or more faults (for example, fractures F59, F105, and F109 on pavement 100). We conclude that the intense fracturing of areas bounded by faults was induced by space problems resulting from displacement along the faults. The other areas of intense fracturing are not clearly attributed to fault displacements.

\section{Fracture Mineralization and Alteration}

Minerals deposited on fracture faces can be useful for determining the relative timing of fracture genesis and for the paleohydrology of a fracture network as will be shown below.

A few of the fractures exposed on the pavements exhibit mineral coatings, some of which completely fill the aperture. Hand-lens inspection showed vaporphase quartz crystals coating two joints on pavements 100 and 300 as shown on plate 1 . The coating is pale orange-brown due to intergrowth of the quartz crystals with oxide minerals (Carlos, 1985). Visually similar coatings commonly line the surfaces of the lithophysal cavities and the tubular structures (described below) on the surfaces of the joints. If these are vapor-phase quartz crystals, then they were most likely deposited during degassing of the tuff. This would suggest that the joints formed very early, soon after emplacement of the tuff.

Another fracture filling found on the pavements is a composite material termed calcrete. Here calcrete consists of angular tuff fragments and sub-angular calcite fragments cemented by a sugary calcite matrix. A calcrete deposit can be observed bridging fracture F/40 on pavement 100 . The calcrete overlies a white calcite coating, which lines the fracture walls, suggesting that the calcite coating is older. Calcrete also fills depressions in all three of the pavement surfaces. We suggest that these calcrete deposits arise from dissolution and reprecipitation of windblown carbonate in evaporating rainwater pools that collect on the debriscovered bedrock surface, thus incorporating tuff fragments.

Dendritic deposits of ferro-manganese oxides and hydroxides are sporadic and can be observed on many of the fracture surfaces as well as much of the pavement surfaces and within the rock matrix. They are small spotty deposits, dark-brown to black in color. These deposits precipitate from solution and are found throughout the volcanic section at Yucca Mountain (Scoll and Castellanos, 1984; Spengler and Chornack. 1984, Carlos, 1985; Zielinski and others, 1986), suggesting to us that surface water has percolated both along fractures and through the rock matrix.

In three areas of fracture intersection on pavement 200 and one on pavement 300 , the tuff matrix has been altered to clay (pl. 1). These areas were excavated during clearing of the pavements and were observed to rapidly accept large quantities of water, and they are identified on plate 1 as areas of anomalously high infiltration. Their stratigraphic extent is not known, but they may be conduits for rapid movement of large quantities of water from the surface into the interior of Yucca Mountain. Alternatively, as suggested by Montazer and Wilson (1984), the fracture pathways may be limited to the welded tuff near the surface so that downward-percolating water is dispersed into deeper nonwelded units.

\section{Fracture Connectivity}

The fluid-flow properties of a fracture network are affected markedly by the degree to which the fractures are interconnected. Fractures that are not interconnected contribute little to flow through the fracture network. Connectivity can be represented by the ratios of the three types of fracture termination or interaction. Fractures may (1) terminate in the rock matrix; we term these "dead" endings. Alternatively, they may (2) cross 


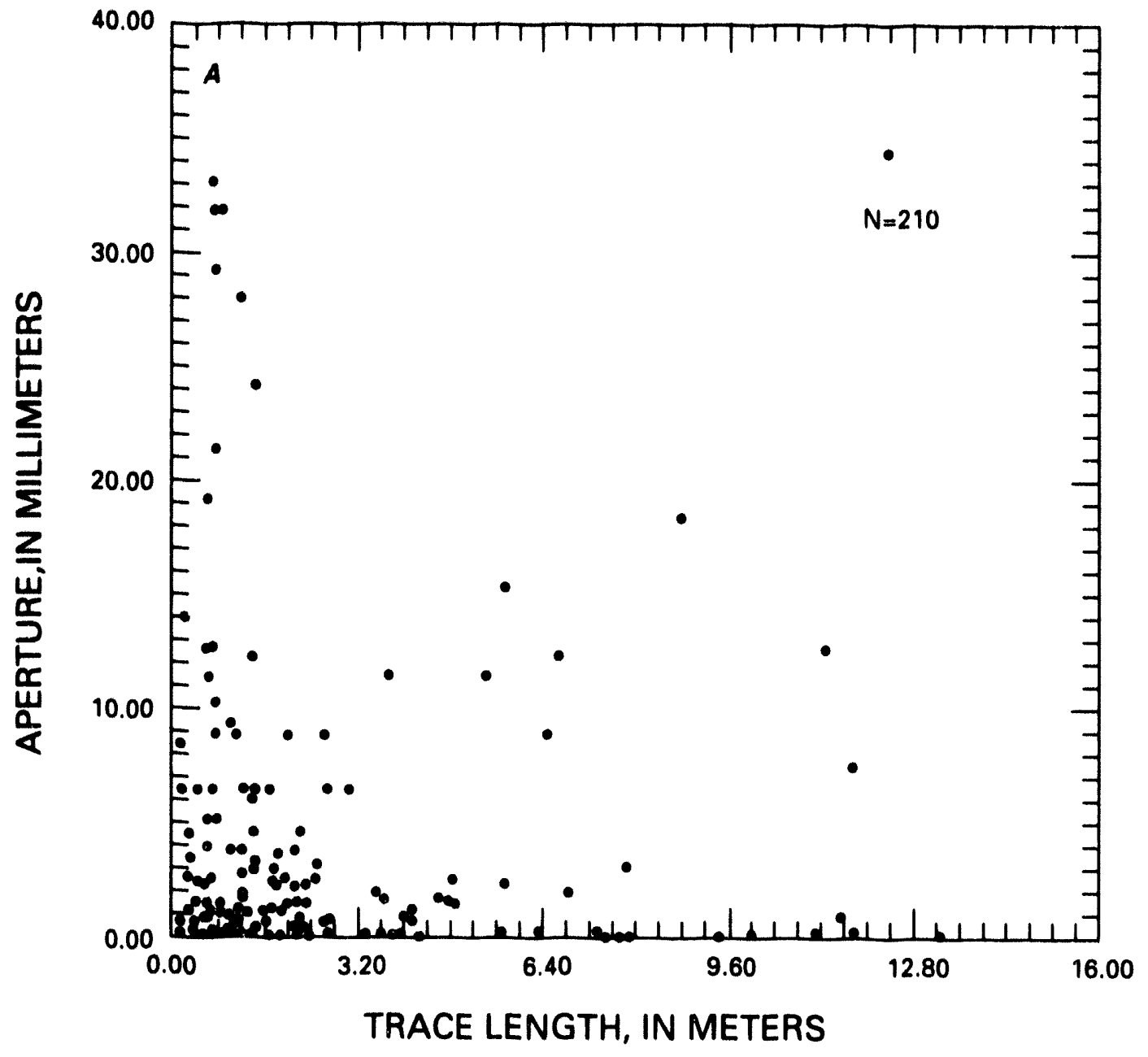

Figure 13A. Diagram of aperture as a function of trace length.

A. Pavement 100; B. Pavement 200; Pavement 300 


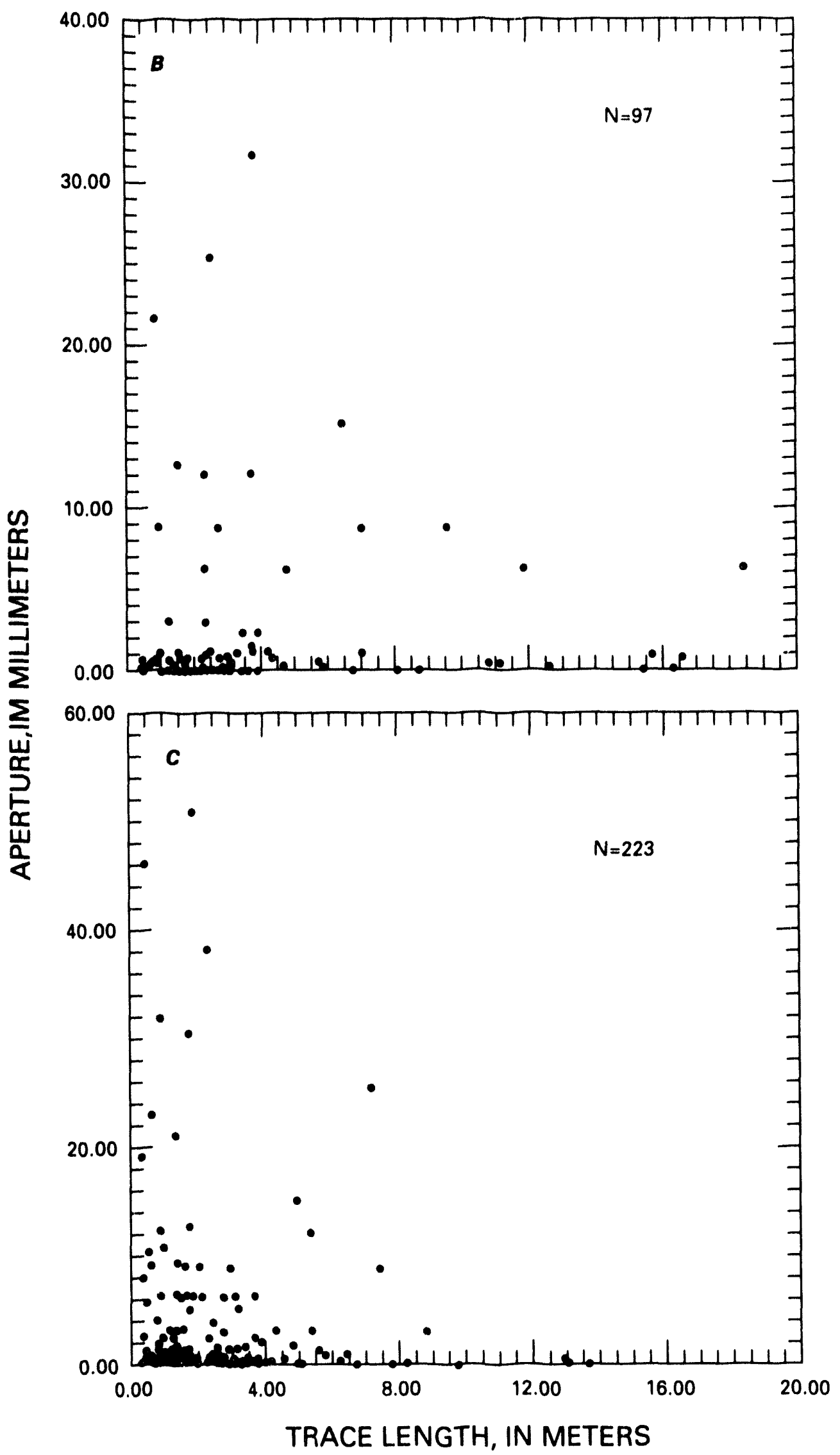

Figure $13 \mathrm{~B}$ and $\mathrm{C}$. Diagram of aperture as a function of trace length

A. Pavement 100; B. Pavement 200; C. Pavement 300--Continued 
or (3) abut other fractures. The percentage of fracture terminations and crossings are shown on figure 14 and listed in table 3. Dead endings and crossings are found in nearly equal proportions, but abuttings are found most frequently. The proportions for all three pavements cluster quite tightly on the ternary diagram (fig. 14).

Table 3. Proportions of Fracture Intersections and terminations

\begin{tabular}{lccc}
\hline Pavement & $\begin{array}{c}\text { Crossing } \\
\text { (percent) }\end{array}$ & $\begin{array}{c}\text { Abutting } \\
\text { (percent) }\end{array}$ & $\begin{array}{c}\text { Dead } \\
\text { (percent) }\end{array}$ \\
\hline $1(0)$ & 27 & 40 & 33 \\
200 & 21 & 51 & 28 \\
$3(0)$ & 24 & 50 & 26 \\
$1(X), 200,300$ & 24 & 47 & 29 \\
combined & & & \\
\hline
\end{tabular}

\section{FRACTURE HISTORY}

A complex pattern of fractures is exposed on the pavements (pl. 1). The pattern consists of two fracture types formed during at least three deformational events (Barton, 1984).

The first type is distinguished by open, anastomosing, matched half-tubes on opposing fracture faces (fig. 15). These fractures show only face separation without shear and are unequivocally joints. Glass spherules adjacent to the joint faces in high concentrations suggest that the joints formed, opened, and their surfaces were quenched before or during devitrification of the tuff. They are thus cooling joints.

The cooling joints make up two well-defined sets, striking 25 to $85^{\circ}$ and 270 to $355^{\circ}$, both dipping perpendicular (plus or minus $6^{\circ}$ ) to foliation. Abutting of fractures of the two sets against each other suggests that they developed coevally. Both sets exhibit 3-to 5-m-wide swarms spaced 150-200 m apart. The rectangular, rather than irregular, polygonal pattern formed by the joint sets may reflect a gravitational stress anisotropy induced by a depositional slope. We suggest this on the basis of our own informal observation that mudcracks developed on a slope often form a rectangular pattern with the long sides of the rectangles parallel to the strike line of the slope, while those on a level surface form an irregular polygonal pattern.

The second fracture type is distinguished from the cooling joints by higher roughness coefficients ( 3 to 18) and by the absence of tubular structures on their faces. These fractures range over all azimuths and do not group into sets based on orientation or roughness. These fractures either abut against or offset the cooling joints and thus postdate them. Six of the frac- tures are northwest-striking, steeply dipping faults that offset cooling joints in a right-lateral sense. They are parallel to the trend of the Las Vegas Valley-Walker Lane regional shear deformation, which is also rightlateral. This suggests that the two may be related.

\section{Tubular Structures}

Open, anastomosing, matched half-tubes on opposing joint faces are present only on the cooling joint faces and are not found in the body of the rock. Tube diameters range from 0.5 to $21 \mathrm{~mm}$. The tubes may exhibit one or two sets based on pitch for a given joint face and vary from face to face, ranging from 0 to $85^{\circ}$ (fig. 16). The tube pitch is given in the appendix. Where two sets are present, the pitch of the second set is given in the remarks column of the appendix.

The anastomosing tubes isolate areas of the joint surface which we refer to as "islands". The surface of each island is slightly convex and tilted relative to neighboring islands. The tilt of the island surfaces relative to the joint surface was measured for a portion of a joint face (see fig. 17). The angle of tilt varies from 0 to $10^{\circ}$; the direction of tilt shows no apparent pattern. The effect of the irregular tilts is to oppose any shear motion along the joint surfaces. This may be why the cooling joints have not been subsequently reactivated in shear even though they are the oldest fractures.

The tubular structure is interpreted to be analogous to bread-crust structure on volcanic bombs (Barton and others, 1984). As stated above, the high concentration of glass spherulites adjacent to the joint faces suggests that the joints formed, opened, and their surfaces were quenched soon after emplacement of the tuff. We surmise that the tubes formed by tensile tearing in response to stretching of the quenched joint surface due to volume expansion of the tuff by exsolution and expansion of trapped volcanic gas that produced the lithophysal cavities during cooling of the tuff. The small range in the ratio of tube area to total joint face area (16 to 22 percent) for four samples, each approximately $0.8 \mathrm{~m}^{2}$ in area, strongly supports this interpretation because it implies a locally uniform volume expansion of the tuff. Extrusion of tuff matrix into some of the tubes due to volume expansion of the tutf during exsolution and expansion of the trapped volcanic gas further supports our interpretation of the timing and mode of origin of the tubes as tears in early formed quenched joint surfaces. The lining of some of the tubes exhibits the sugary vapor phase coating of quartz observed coating the surfaces of lithophysal cavities and some of the cooling fractures. These coatings must have been deposited soon after the tuff was 


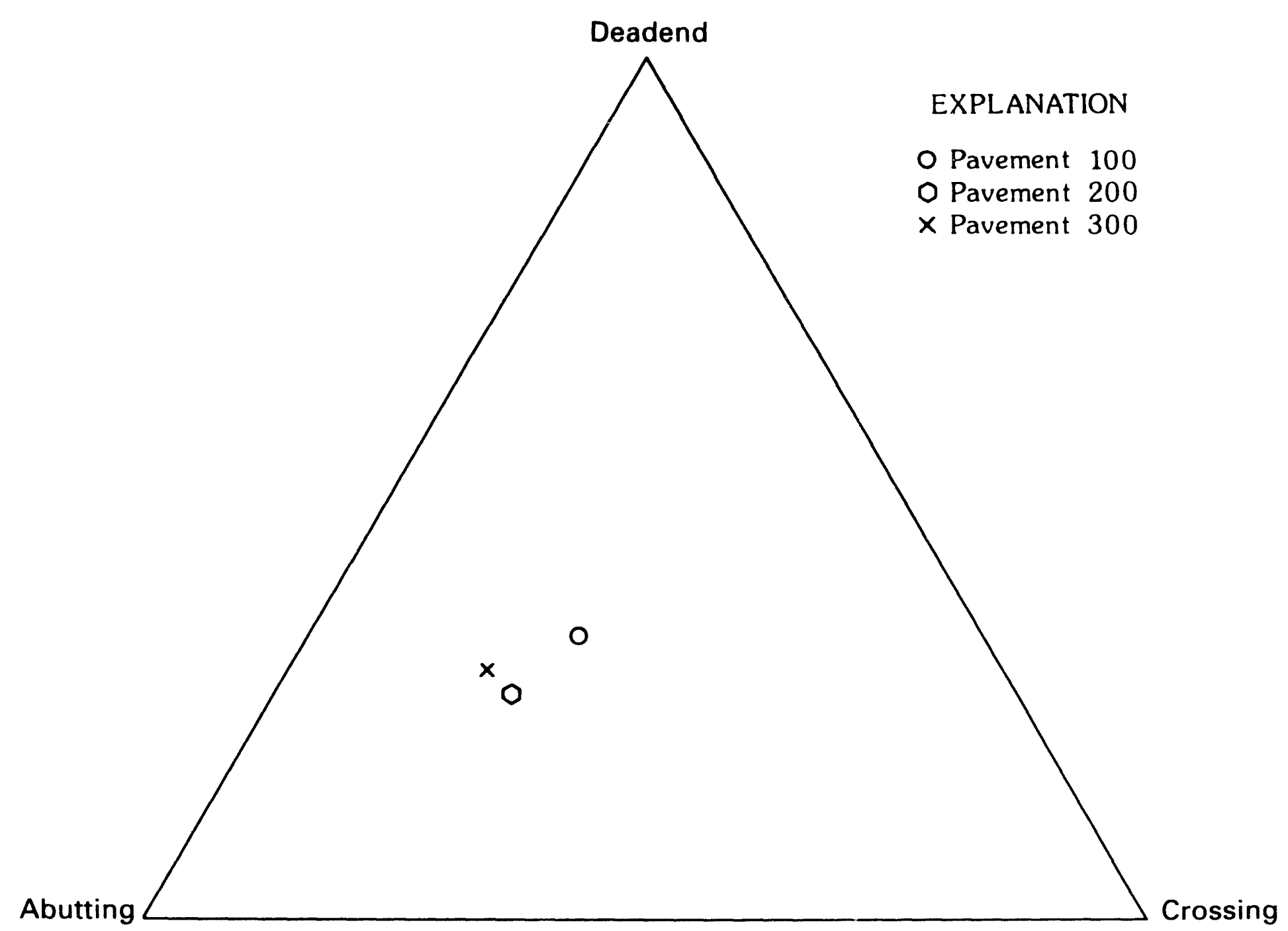

Figure 14. Ternary diagram of percentages of fracture intersections and terminations for pavements 100,200 , and 300 . 


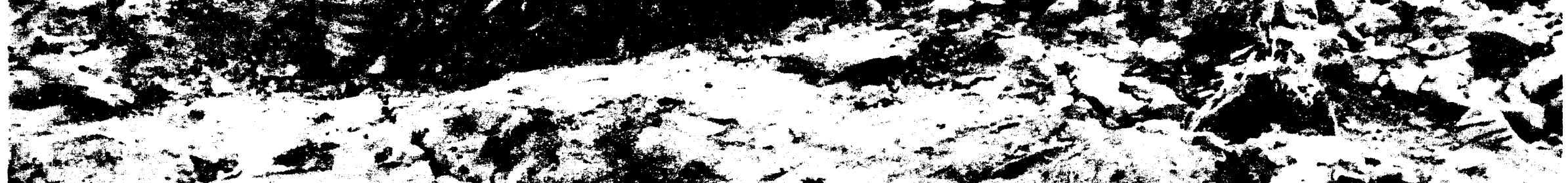

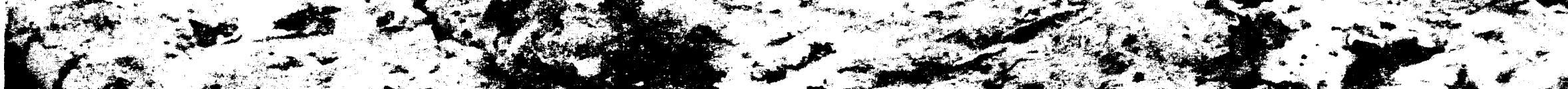

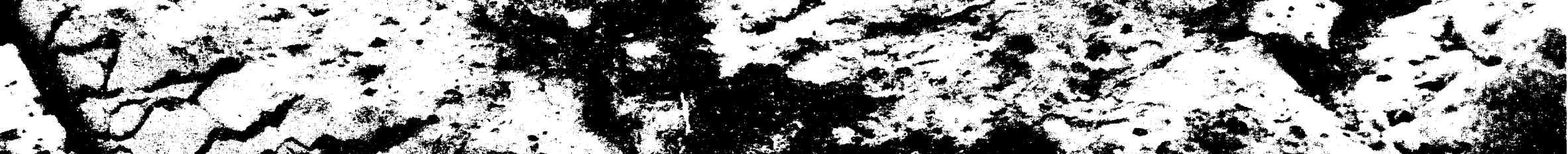

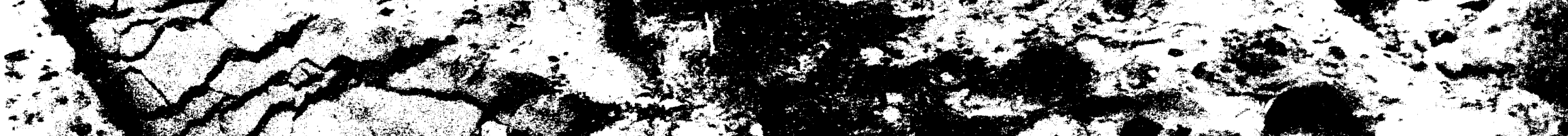

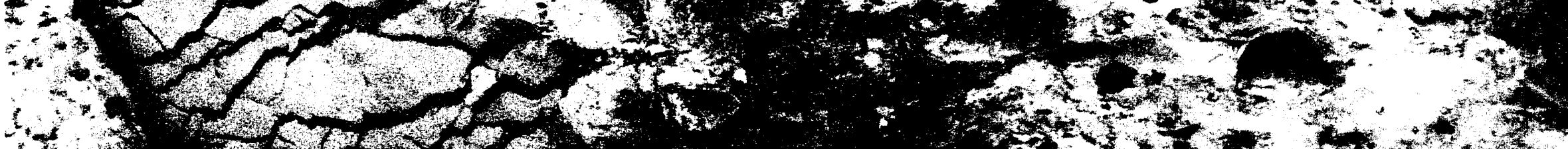

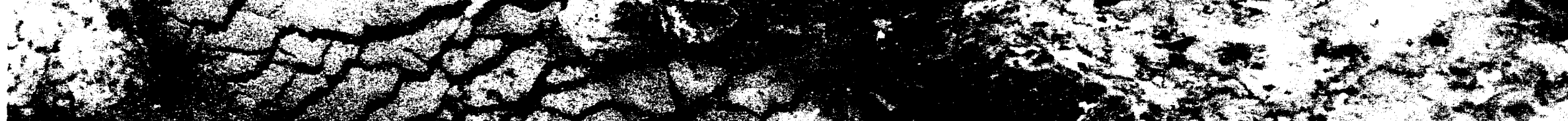

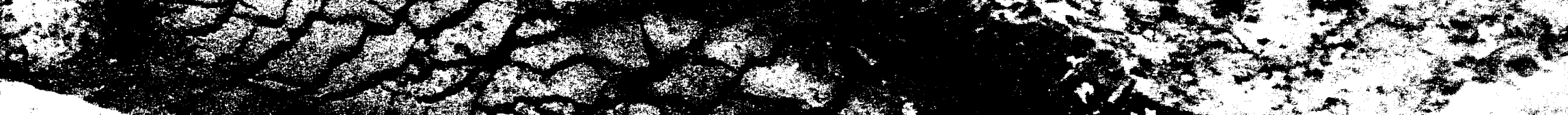

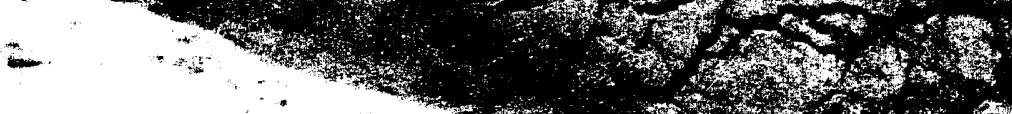

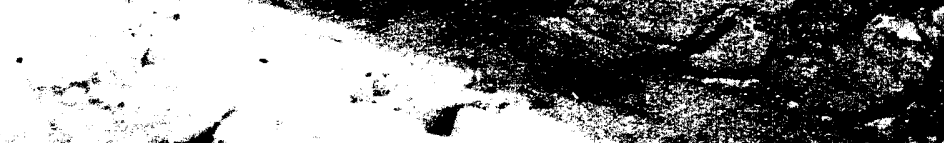

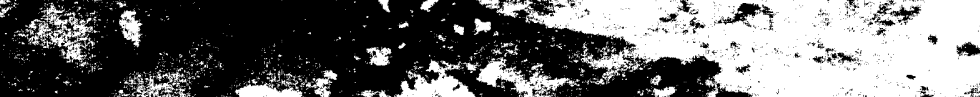

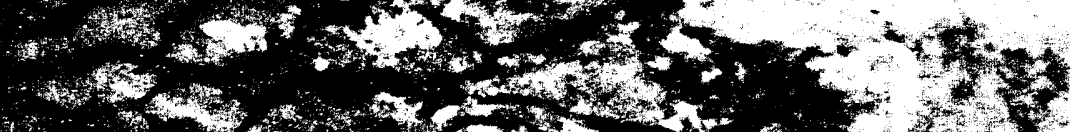

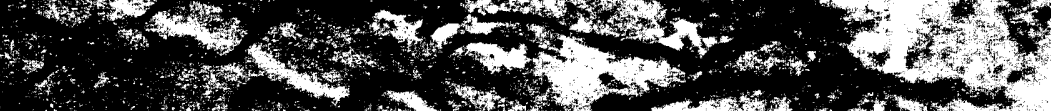

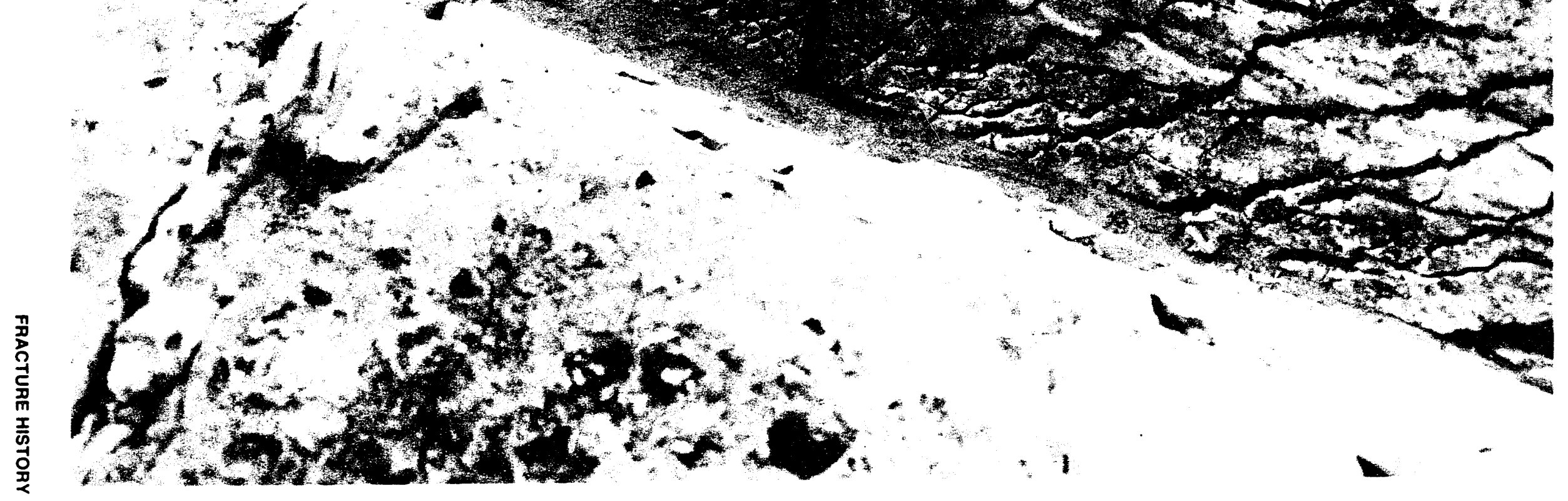


(In percent)

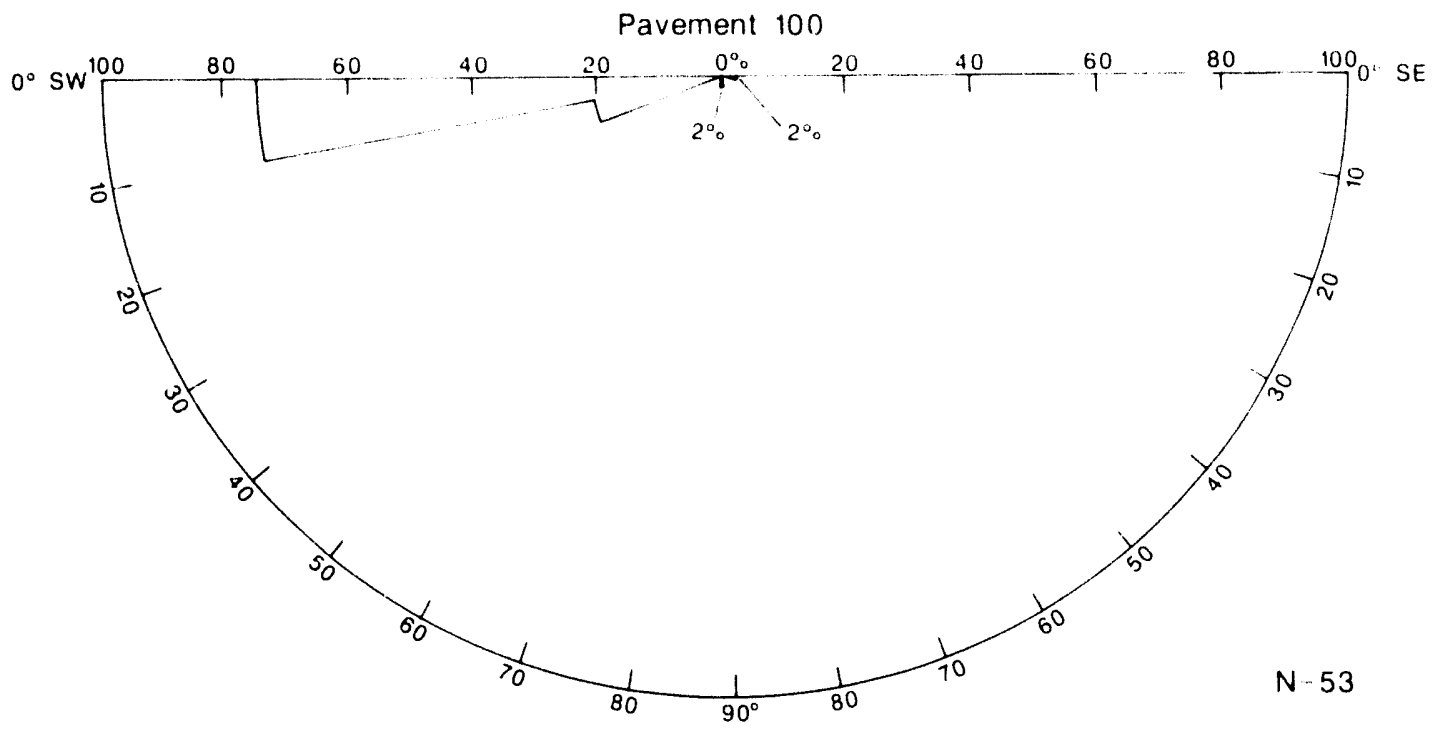

Pavement 200

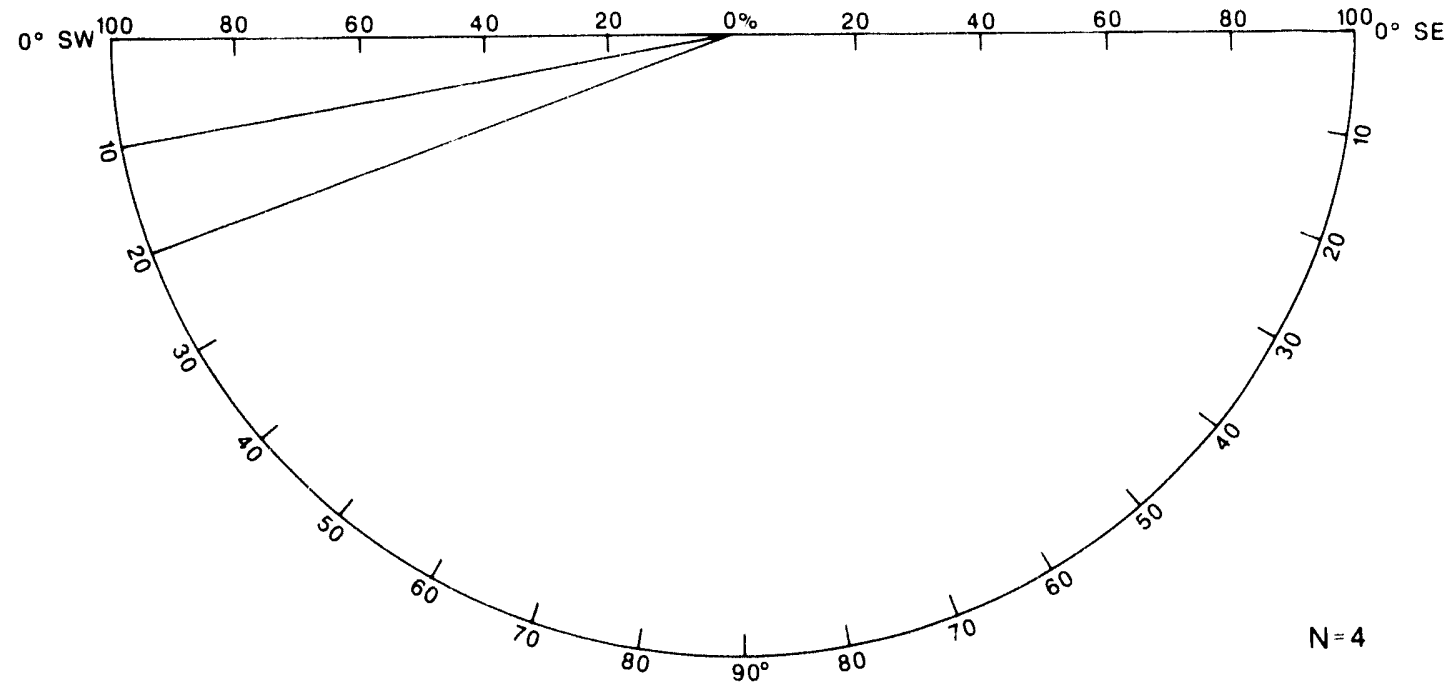

Pavement 300

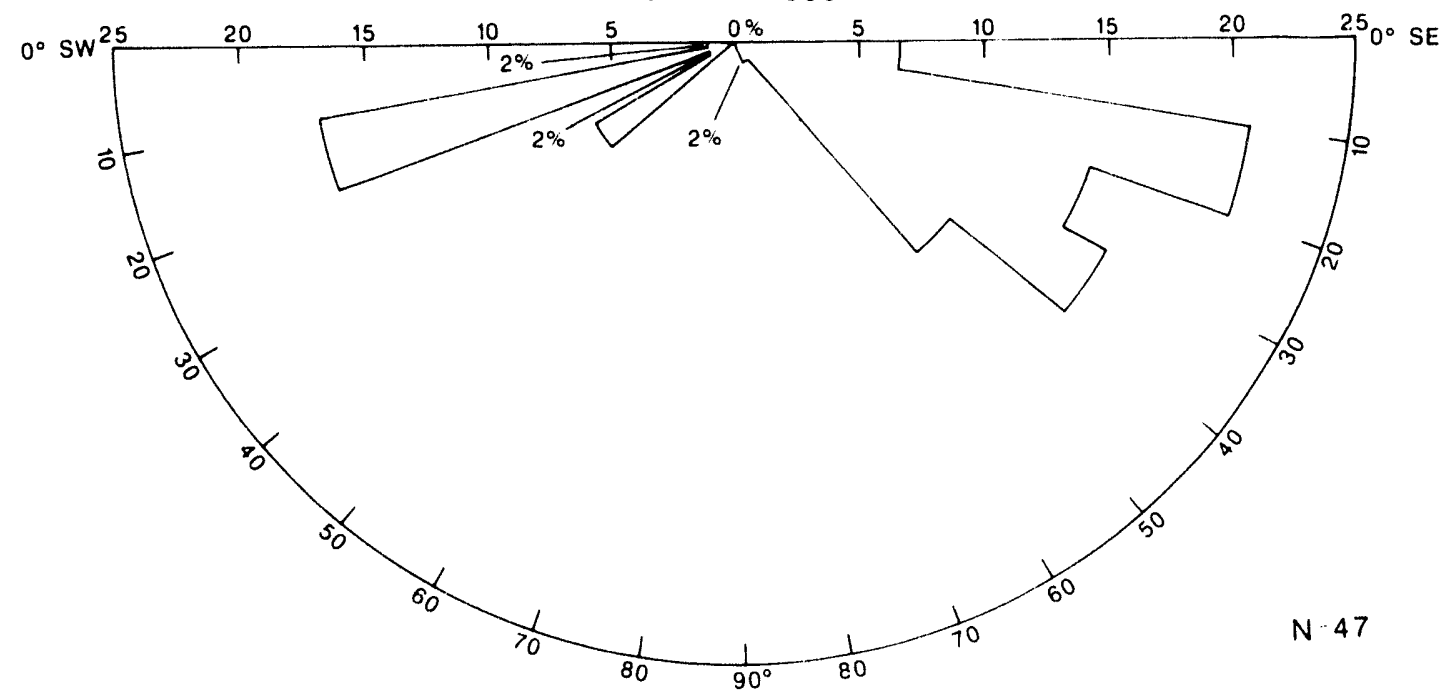

Figure 16. Diagrams of the distribution of the pitch of tubes on joints for pavements 100,200 , and 300 . 


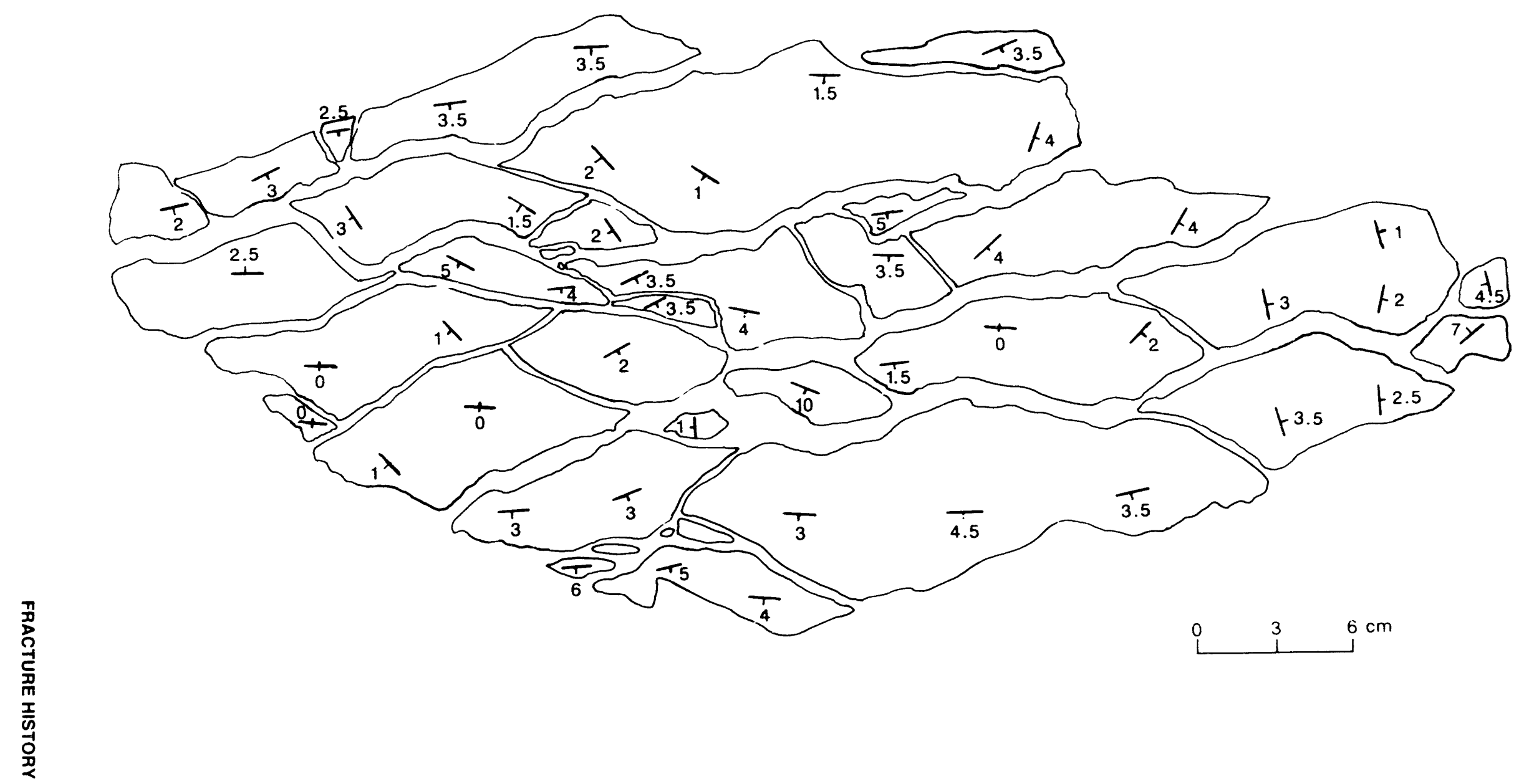

Figure 17. Plan view of a portion of a joint surface showing the direction and angle of dip for island surfaces. 
emplaced, probably by the same volcanic gas that formed the lithophysal cavities. This is further evidence for the early formation of the cooling joints which must have formed prior to the tubular structures.

\section{FRACTAL GEOMETRY OF THE FRACTURE NETWORKS}

Fracture networks in rock are present over a wide range of scales, from the largest faults down to microfractures. The contribution of fracture networks to fracture-flow, mechanical stability, and physical properties of rock is not a function of the fractures at any one particular scale, but rather is the sum of the contribution of fractures at all scales. Therefore, it is useful to know the scaling function for fracture networks over a wide range of scales. The concept of fractal geometry is particularly useful for investigating scaling of complex objects if they are self-similar. Here, selfsimilarity means the replication of the statistical properties of geometric patterns over a range of scale. Thus, fractal patterns possess dilatation and reduction symmetry. Fractal geometry applied to two-dimensional fracture-trace networks simultaneously and jointly quantifies the spatial, trace-length, and orientation distributions (Barton and Larsen, 1985; Barton and others, 1985 and 1986; Barton and Hsieh, 1989).

We have greatly improved our technique for determining the fractal properties of fracture-networks. The use of computers permits us to easily sample a greater number of intermediate scales than we could in our earlier papers and thereby to more finely sample the fractal behavior and more accurately determine the fractal dimension of the networks.

Our investigations of the box method also indicate that the range of box sizes for sampling the fractal properties of a fracture network is limited by the network itself. The smallest box size should be no smaller than the shortest fracture in the network, while the largest box size should be smaller than the size at which all the boxes are occupied. The fractal dimensions for pavements 100,200 , and 300 were reported previously as ranging from 1.12-1.16 (Barton and Larsen, 1985). These values were calculated for cell sizes at or below the shortest fracture length and thus are unrepresentative of the fracture network. The same maps were reanalyzed in Barton and Hsieh (1989) including box sizes that were too large; the fractal dimensions reported ranged from 1.6-1.7.

We use a variation of the box method which we term the box-flex method for fractal analysis, developed by the senior author. In this method, grids of various-sized square cells are placed successively over the maps, and the number of cells intersected by fracture traces counted. The outer boundaries of the grid are permitted to expand (or flex) so that the box size can be changed by very small increments. For each of the plots shown on figure 18, fifty different box sizes were used, which produces a fractal dimension with an accuracy of plus or minus 0.05 .

The fractal distribution of lines on a map is

$$
\mathrm{Nr}{ }^{\mathrm{D}}=1
$$

or equivalently

$$
D=\log N / \log (I / r)
$$

where $\mathrm{N}$ is the least number of cells containing portions of one or more fracture traces, $r$ is the length of the side of each cell, and $D$ is the fractal dimension. On figure 18 , the $\log (1 / r)$ is plotted versus $\log (N)$ for each element size. The fractal dimension $D$ is the slope of a straight line fitted to the points. The fractal dimensions of all three networks lic between I the dimension of a straight line) and 2 (the dimension of a filled plane). Pavement 100 has a fractal dimension of 1.5; pavement 200, 1.4; and pavement 300, 1.5, all determined to confidence levels of 0.99 .

Because the points can be fitted by smooth lines (either straight or curved), the networks can be said to be fractal over the range of $r$ sampled. Because these lines are straight (not curved), the networks can also be said to be scale independent over the same range. The fractal dimension is a quantitative measure of scaling. The fractal dimension for a fourth pavement (pavement 100), mapped at 1:50 in the orange-brick unit of the Topopah Spring Member of the Miocene Paintbrush Tuff at Yucca Mountain is 1.7 (figure 18) which is significantly higher than the dimensions $1.4-1.5$ determined for the three pavements mapped at 1:50 in the upper-lithophysal unit of the Tiva Canyon Member. The fractal dimension for the network of faults mapped at 1:12,000 by Scott and Bonk (1984) is 1.5 (figure 18), which is equal to the average of the range of the dimensions for the four pavements included in this study. This suggests that the fractal properties of tracture networks are scale independent over a broad range of scales at Yucca Mountain and are independent of the mode of origin of the fractures as faults or joints. If fractal analyses of future fracture maps at different scales and locations on Yucca Mountain have the same range as the results presented above, then it will be acceptable to map fractures at one scale and extrapolate the spatial and statistical geometric properties to larger and smaller scales.

Once the fractal dimension of a pattern or object in nature is determined, it is possible to model that pattern or object from a single generator. A generator is 


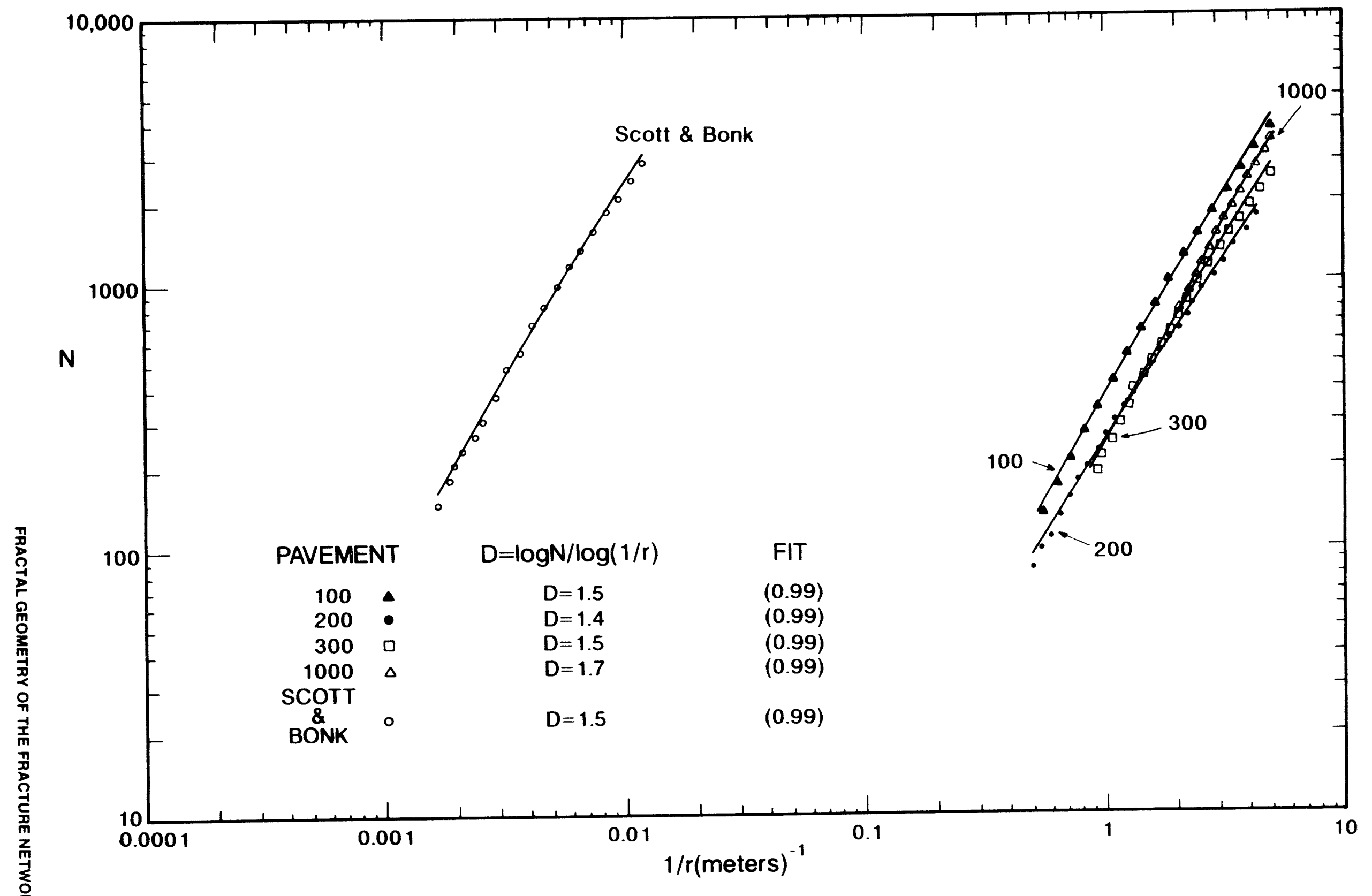


the fundamental building block from which a fractal pattern or object is generated by iterative replacement of each piece of the generator by a reduced version of the generator. The task of deducing a generator for a particular fractal pattern observed in nature is not easy. One approach is to guess the generator as was done by King (1983) for the map pattern of the traces of subsidiary faults in the immediate vicinity of large-scale fault bends. The box method has an intrinsic upper limit of 2.0 for the fractal dimension of patterns of lines lying in a plane. Nonoverlapping fractal generators that lie in a plane also have an upper limit of 2 , while overlapping fractal generators lying in a plane can exceed 2.0. For ten pavements we have studied, we have not found fractal dimensions of fracture traces to exceed 1.7, and we conclude that their generators are not space filling. In order to simulate fault patterns, King (1983) proposed a three dimensional space-filling generator, but assumed that it was never fully formed. In a twodimensional section, the equivalent is a fractal dust with a dimension of 1.0 which falls below the values we have measured for the pavements which are also two dimensional. We commonly observe crosscutting fractures on our maps which suggest that a proper generator for modeling fracture trace patterns should be overlapping. The generator proposed by King (1983) was for shear faults that did not overlap and therefore is not appropriate for the patterns of crossing fractures. We have been unsuccessful at guessing a generator for modeling our fracture-trace maps. A most promising method for deducing a fractal generator is the iterated function systems approach being developed by Barnsley and Demko (1985) which systematically deduces a fractal generator for a given fractal object.

\section{PATTERN OF DEVELOPMENT OF FRACTURE NETWORKS}

Fracture networks evolve from initially ordered to increasingly disordered patterns. Fracture networks become more complex with time as new fracture generations are added to those that already exist. Generations of fractures form during discrete episodes, each of which records a discrete element of the tectonic history. Most episodes of fracturing are not accompanied by major tectonic deformations such as folding and faulting. If we can determine that the fractures in a network formed in extension, then we can determine the relative ages on the basis of abutting relations-younger fractures abut older ones. We have thus analyzed joint patterns mapped on pavements 100,200, and 300 .

Analysis of fracture characteristics from one generation to the next reveals the following pattern of fracture-network development. In general, the first- generation fractures (i.e. the cooling fractures) are long, subparallel, and connectivity is poor. Secondgeneration fractures are shorter and abut the firstgeneration fractures, generally at high angles, to form large, polygonal blocks; connectivity is improved. Fractures of subsequent younger generations are generally shorter, more diversely oriented, and increase connectivity greally. The younger fractures define small. irregular polygonal blocks bounded by the older fricitures. The pattern of evolution should begin again when mineral infillings mechanically heal previous fracture generations. This predicts that one or more stages of infilling are required to permit highly ordered fracture patterns composed of more than one or two generations of fractures. Highly ordered fracture patterns are not observed in the stratigraphic section at Yucca Mountain, probably because there has been litlle healing of fractures by mineral infilling.

The spatial distribution of fractures and connectivity within the network evolve as fractures are sequentially added to the network. The fractal dimension of patterns of fracture traces, ranges from about 1 for early stages of network development 101.7 for mature networks. Connectivity within the network is low during initial stages of development and increases as more fractures are added.

During evolution of the network, larger blocks are preferentially broken by subsequent fracturing; this process reduces the range of block sizes. The opposite has been reported for comminution by grinding which produces a fractal distribution of particle sizes over six orders of magnitude in scale (Sammis and Biegel,

1989; Turcotte, 1986); this suggests that the physics of grinding involves more than fracturing.

Younger fractures apparently formed in response to local stress conditions within the blocks in which they formed, and thus are less useful than first generation fractures for determination of regional paleostress orientations. The evolution of fracture patterns described above is the basis for our computer generation of synthetic fracture networks (Barton and others, 1987).

\section{DISCUSSION}

A method for characterizing fractures for fluidflow, geomechanical, and paleostress modeling has been developed and applied at three localities in the vicinity of USW G-4 at Yucca Mountain. The basis for the method is clearing pavement exposures and making a map of fracture traces and intersections. This method provides for optimal sampling of the characteristics of both individual fractures and fracture networks. The standard geologic methods for characterizing fractures use outcrops, boreholes and cores, and aerial photo- 
graphs. These methods, alone or in combination, rarely permit measurement of the variety of fracture data with the accuracy that the pavement method permits. The pavement method is feasible wherever debris cover can be removed.

Outcrops permit measure of orientation, roughness, mineralization, aperture, and tectonic features. But, normally there is little choice in where to measure these characteristics because only a very small portion of each fracture is exposed. Where outcrop size is limited, usually it is not possible to determine trace length, spatial distribution of traces and their intersections, connectivity, or the sizes, shapes, and geometries of blocks bounded by fractures. These are characteristics of the network that are necessary for hydrologic, geomechanical. and paleostress modeling.

Boreholes and cores together can provide orientation, roughness, mineralization, aperture, and tectonic features. But, there is very little choice of where to measure these characteristics because only a very small portion of the fracture is recovered or exposed in the borehole wall. It is impossible to determine trace length. spatial distribution of traces and intersections, connectivity, most abutting relations, or the size, shape, and spatial distribution of blocks bounded by fractures. The primary limitation of boreholes and cores is that they are a one-dimensional sampling of a threedimensional fracture network. Moreover, in flat-lying strata, boreholes and cores are normally subparallel to the dip of most of the fractures. They provide a limited and biased sampling of fractures that cannot be corrected by statistical analysis.

Aerial photographs have proven to be the poorest method at Yucca Mountain. At best they could provide trend (but not dip) and spatial patterns and densities. At Yucca Mountain they cannot even provide these characteristics; linear features on the photographs have been shown not to correspond to fractures on the ground (Throckmorton, 1987).

The pavement method is not perfect, but it does permit a more accurate and complete sampling of the individual and network characteristics of fractures. Pavements are only a two-dimensional sampling of a three-dimensional fracture network. Optimally, a comprehensive study will include pavements in three perpendicular planes.

The size of pavements is necessarily limited by time, funding, and environmental constraints. The size of all of these pavements falls short of revealing a characteristic, representative elementary area of the fracture pattern. A larger pavement, $1720 \mathrm{~m}^{2}$ in area in the same upper lithophysal unit of the Tiva Canyon memher exposed on top of Busted Butte, $9 \mathrm{~km}$ to the south and mapped subsequent to this study, does not reveal a representative elementary area with a characteristic length scale (Bear, 1972) for the fracture pattern. implying either that prohibitively large pavements are required or that there is no representative elementary area for the fracture pattern in this unit. The fractal behavior of fracture and fault-trace patterns discussed above strongly suggests that they are self-similar and scaling over a broad range of scales at Yucca Mountain. Therefore, fractal geometry of the fracturetrace patterns is useful for extrapolating scaling and statistical geometric properties both upward and downward in scale from the necessarily limited scale of the pavements.

Pavements at the ground surface are subject to weathering and stress release. Underground, exposures are subject to the stress redistribution around all underground surfaces. Nevertheless, we conclude that the pavement method is at present the best method for characterizing fractures and fracture networks for hydrologic, geomechanical, and paleostress modeling.

\section{CONCLUSIONS}

A complex network of fractures was exposed on three 214- to $260-\mathrm{m}^{2}$ pavements cleared of debris in the upper lithophysal unit of the Tiva Canyon Member of the Miocene Paintbrush Tuff (pl. 1).

The network consists of two fracture types. The first type is distinguished by low surface roughness coefficients ( 95 percent are 1 to 4 ) and by open, anastomosing, matched half-tubes on opposing fracture faces. These fractures show only face separation without shear and are termed joints. Glass spherulites adjacent to joint faces suggest that the joints formed, opened. and their surfaces were quenched before or during devitrification of the tuff, and are thus cooling joints. The tubular structure is interpreted to be analogous to bread-crust structure on volcanic bombs. The cooling joints make up two well-defined sets striking $25-85^{\circ}$ and $270-355^{\circ}$, both dipping perpendicular (plus or minus $6^{\circ}$ ) to foliation. Abutting of the two sets against each other suggests that they developed coevally. Both sets exhibit 3- to 5-m-wide swarms spaced 150)-200 m apart. The second fracture type is distinguished by higher surface roughness coefficients ( 98 percent are 4 to 18) and by the absence of tubular structures on their faces. Six of these fractures have demonstrable rightlateral shear offset and are thus faults. For most of the second type of fractures, is was not possible to determine whether there was any shear displacernent, and these are referred to as fractures. The fractures abut against and the faults offset the cooling joints, thus, both postdate the joints. Unlike the cooling joints, 
these fractures do not form sets based on orientation or surface roughness.

The surface-roughness coefficients for the fractures and faults combined are normally distributed with peaks at $R C=10$. The $R C$ for the cooling joints is also normally distributed with peaks at $R C=2$. Aperture frequency and trace-length frequency are best fit by power laws.

The networks of fractures, joints, and faults mapped on the three pavements exposed in the upper lithophysal unit of the Tiva Canyon member of the Paintbrush tuff are shown to be fractal, and the fractal dimensions (D) are 1.5, 1.4, 1.5.

\section{ACKNOWLEDGMENTS}

We gratefully acknowledge Kurt Sternlof, Mark Yallom, David Verardo, and Robert Scott of theU.S. Geological Survey, and Kirstin Johnson, Sandra Waddell, and Michael Chornack of Fenix \& Scisson, Inc. for their assistance in clearing the pavements. Work was performed under Interagency Agreement DE-AI08-78ET44802 with the U.S. Department of Energy. Analysis and interpretation of the data presented in this paper have been limited by a stop-work order that prevented the collection of additional data and the re-examination of the pavement sites.

\section{REFERENCES CITED}

Barnsley, M.F., and Demko, S., 1985, Iterated function systems and the global construction of fractals: Proceedings of the Royal Society of London, A399, p. 243-275. (NNA.920814.0107)

Barton, C.C., 1984, Tectonic significance of fractures in welded tuff, Yucca Mountain, southwest Nevada (abs.): Geologic Society of America, Abstracts with Programs, v. 16, no. 6, p. 438. (HQS.880517.1057)

Barton, C.C., and Hsieh, P.A., 1989, Physical and hydrologic flow properties of fractures: Field trip guidebook T385: International Geologic Congress, 28th, Washington, D.C., American Geophysical Union, 36 p. (HQX.890818.0028)

Barton, C.C., Howard, T.M., and Larsen, Eric, 1984, Tubular structures on the faces of cooling joints-A new volcanic feature (abs.): Eos, Transactions of the American Geophysical Union, v. 65, no. 45, p. 1148.

(NNA.920814.0109)

Barton, C.C., and Larsen, Eric, 1985, Fractal geometry of two-dimensional fracture networks at Yucca Mountain, southwest Nevada, in Stephannson, Ove, ed., Fundamentals of rock joints: Proceedings of the International
Symposium on Fundamentals of Rock Joints, Bjorkliden, Sweden, p. 77-84. (NNA.920727.0028)

Barton, C.C., Larsen, Eric, and Baechle, P.E., 1985, Fractal geometry of two-dimensional sections through fracture networks at Yucca Mountain, southwestern Nevada (abs.): Eos, Transactions of the American Geophysical Union, v. 66, no. 46. p. 1089. (HQS.880517.3020)

Barton, C.C., Gott, C.B., and Montgomery, J.R., 1986, Fractal scaling of fracture and fault maps at Yucca Mountain, southern Nevada (abs.): Eos (Transactions of the American Geophysical Union), v. 67, no. 44, p. 870. (HQS.880517.3021)

Barton, C.C., Page, W.R., and Larsen, Eric, 1986, Pattern of development of fracture networks: Geologic Socicty of America, Abstracts with Programs, v. 18, no. 6, p. 536. (NNA.920616.0002)

Barton, C.C., Schutter, T.A., Page, W.R., and Samuel, J.K., 1987. Computer generation of fracture networks for hydrologic-flow modeling: Eos (Transactions of the American Geophysical Union), vol. 68, no. 44, p. 129. (NNA.920814.0108)

Barton, N.R., and Choubey, V., 1977. The shear strength of rock joints in theory and practice: Rock Mechanics, v. 10, p. 1-54. (HQS.880517.2610)

Bear, Jacob, 1972, Dynamics of fluids in a porous media: American Elsevier, New York, 746 p. (NNA.890713.0163)

Brown, S.R., and Scholz, C.H., 1985, Closure of random elastic surfaces in contact: Journal of Geophysical Research, v. 90, no. B7, p. 5531-5545. (NNA.900403.0013)

Byers, F.M., Jr., Carr, W.J., Orkild, P.P., Quinlivan, W.D., and Sargent, K.A., 1976, Volcanic suites and related cauldrons of Timber Mountain-Oasis Valley caldera complex, Southern Nevada: U.S. Geological Survey Professional Paper 919, 70 p. (NNA.870406.0239)

Carlos, B.A., 1985, Minerals in fractures in the unsaturated zone from drill core USW G-4, Yucca Mountain, Nye County, Nevada: Los Alamos National Laboratory Report LA-10415-MS, 55 p. (HQS.880517.1112)

Cook, N.G.W., 1992, Natural joints in rock; mechanical, hydraulic and seismic behavior and properties under normal stress: Jaeger Memorial Lecture, presented at the 29th U.S. Symposium on Rock Mechanics, 1988, International Journal of Rock Mechanics and Mining Sciences and Geomechanics Abstracts, v. 29, no. 3, p. 198-223. (NNA.930602.0002)

Dershowitz, William, Geier, J., Axelsson, C.L., 1991, Application of discrete feature analysis to repository characterization: High Level Radioactive Waste Management and Proceedings of the Second Annual Conference, Las Vegas, Nevada, April 28-May 3, 1991, American Society of Civil Engineers, New York, p. 272-278. (NNA.920917.0056) 
Goodman, R.E., and Shi, G.H., 1985, Block theory and its application to rock engineering: Englewood, N.J., Prentice-Hall, 388 p. (NNA.890522.0212)

Haimson, B.C., Lacomb, J., Jones, A.H., and Green, S.J., 1974, Deep stress measurement in tuff at the Nevada Test Site: Advances in Rock Mechanics, v. Ila, National Academy of Sciences, Washington D.C., p. 557-561. (NNA.920917.0057)

King, G.C.P., 1983, The accommodation of large strains in the upper lithosphere of the earth and other solids by self-similar fault systems: the geometric origin of b-value: Pure and Applied Geophysics, V. 121, no. 5/6, p. 761-816. (NNA.920616.0003)

Kulander, B.R., Barton, C.C., and Dean, S.L., 1979, Applications of fractography to core and outcrop investigations: U.S. Department of Energy Report METC/SP.79/3, 179 p. (NNA.920727.0030)

La Pointe, P.R., and Hudson, J.A., 1985, Characterization and interpretation of rock mass joint patterns: Geological Society of America Special Paper 199, 37. p. (NNA.920616.0004)

Lemos, J.V., Hart, R.D., and Cundall, P.A., 1985, A generalized distinct element program for modelling jointed rock mass, in Stephannson, Ove, ed., Fundamentals of rock joints: Proceedings of the International Symposium on Fundamentals of Rock Joints, Bjorkliden, Sweden, p. 335-343 (NNA.920727.0029)

Long, J.C.S., 1983, Investigation of equivalent porous medium permeability in networks of discontinuous fractures: Lawrence Berkeley National Laboratory Repon LBL-16259, 277 p. (NNA.92101'0194)

Long, J.C.S., Endo, H.K., Karasaki, Kenzi, Pyrak, Laura, MacLean, Peggy, and Witherspoon, P.A., 1985, Hydrologic behavior of fracture networks, in Hydrology of rocks of low permeability: International Association of Hydrogeologists, Memoirs, v. 17, part 2, Proceedings, (published by a committee of U.S.A. members of the International Association of Hydrogeologists), p. 449-462. (NNA.920814.0110)

Mandelbrot, B.B., 1982, The fractal geometry of nature: San Francisco, Calif., W.H. Freeman and Co., 460 p. (NNA.900123.0062)

Montazer, Parviz, and Wilson, W.E., 1984, Conceptual hydrologic model of flow in the unsaturated zone, Yucca Mountain, Nevada: U.S. Geological Survey Water Resources Investigations Report 84-4345, 55 p. (NNA.870519.0109)

Olson, Jon, and Pollard, D.D., 1989, Inferring paleostress from natural fracture patterns: a new method: Geology, v. 17, no. 4, p. 345-348. (NNA.920814.0106)

Robinson, P.C., 1984, Connectivity, flow and transport in network models of fractured media: Ph.D. dissertation, Oxford University, Oxford, England, 154 p.

(NNA.930602.0008)
Rogers, A.M., Harmsen, S.C., Carr, W.J., and Spence, W., 1983, Southem Great Basin seismological data report for 1981 and preliminary data analysis: U.S. Geological Survey Open-File Report 83-669, 243 p. (NNA.870427.0085)

Sammis, C.G., and Biegel, R.L., 1989. Fractals, fault-gouge, and friction: Pure and Applied Geophysics, vol. 131, nos. 1/2, p. 255-272. (NNA.910215.0266)

Science Applications International, 1988, Yucca Mountain Project Site Atlas, Volume 1: U.S. Department of Energy, YMP/88-21, Geologic Pavements, Section 4.1.10, p. 1-7. (NNA.920917.0063)

Scott, R.B., 1984, Internal deformation of blocks bounded by Basin-and-Range-style faults (abs.): Geological Society of America, Abstracts with Programs, v. 16, no. 6, p. 649. (HQS.880517.1441)

Scott, R.B., 1986, Extensional tectonics at Yucca Mountain, southern Nevada (abs.): Geological Socicty of America, Abstracts with Programs, v. 18, no. 5, p. 411. (HQS.880517.1442)

Scott, R.B., Bath, G.D., Flanigan, V.J., Hoover, D.B., Rosenbaum, J.G., and Spengler, R.W., 1984, Geologi$\mathrm{cal}$ and geophysical evidence of structures in northwest-trending washes, Yucca Mountain, southern Nevada, and their possible significance to a nuclear waste repository in the unsaturated zone: U.S. Geological Survey Open-File Report 84-567, 23 p. (NNA.870519.0101)

Scott, R.B., and Bonk, Jerry, 1984, Preliminary geologic map of Yucca Mountain, Nye County, Nevada, with geologic sections: U.S. Geological Survey Open-File Report 84-494, scale 1:12,000. (HQS.880517.1443)

Scott, R.B., and Castellanos, Mayra, 1984, Stratigraphy and structural relations of volcanic rocks in drill holes USW GU-3 and USW G-3, Yucca Mountain, Nye County, Nevada: U.S. Geological Survey Open-File Report 84-491, 121 p. (NNA.890804.0017)

Segall, Paul, and Pollard, D.D., 1983a, Joint formation in granitic rock of the Sierra Nevada: Geologic Society of America Bulletin, v. 94, p. 563-575. (NNA.920616.0005)

Segall, Paul, and Pollard, D.D., 1983b, Nucleation and growth of strike slip faults in granite: Journal of Geophysical Research, v. 88, no. B1, p. 555-568. (NNA.920616.0006)

Spengler, R.W., and Chornack, M.P., 1984, Stratigraphic and structural characteristics of volcanic rocks in core hole USW G-4, Yucca Mountain, Nye County, Nevada, with a section on geophysical logs by D.C. Muller and J.E. Kibler: U.S. Geological Survey Open-File Report 84-789, 77 p. (NNA.890804.0012)

Springer, J.E., Thorpe, R.K., and McKague, H.L., 1984, Borehole elongation and its relation to tectonic stress at the Nevada Test Site: Lawrence Livermore National 
Laboratory Report UCRL-53528, $43 \mathrm{p}$.

(HQS.880519.1711)

Stock, J.M., Healy, J.H., Hickman, S.H., and Zoback, M.D., 1985, Hydraulic fracturing stress measurements at Yucca Mountain, Nevada, and relationship to the regional stress field: Journal of Geophysical Research, v. 90, no. B10, p. 8691-8706. (HQS.880517.1509)

Throckmorton, C.K., 1987, Photogeologic study of linear features near a potential nuclear-waste repository site at Yucca Mountain, southem Nye county, Nevada: U.S. Geological Survey Open-File Report 87-409, 54 p. (HQX.880125.0018)

Turcolte, D.L., 1986, Fractals and fragmentation: Journal of Geophysical Research, vol. 91, no. B2, p. 1921-1926. (NNA.920605.0070)

U.S. Geological Survey, 1984, A summary of geologic studies through January 1, 1983, of a potential high-level radioactive waste repository site at Yucca Mountain. southern Nye County, Nevada: U.S. Geological Survey Open-File Report 84-792, 103 p. (NNA.891009.0304)

Verbeek, E.R., and Grout, M.A., 1989, Variation in fracture network characteristics among coexisting lithologies of Mesaverde group, DeBeque Canyon, western Colorado: American Association of Petroleum Geologists, Bulletin, vol. 73, no. 9. p. 1177. (NNA.920814.0105)

Wu, S.S.C., 1985, Topographic maps of Yucca Mountain area, Nye County Nevada: U.S. Geological Survey Open-File Report 85-620, scale 1:5000. (HQS.880517.1929)

Zielinski, R.A., Bush, C.A., Spengler, R.W., and Szabo, B.J., 1986, Rock-water interaction in ash-flow tuffs (Yucca Mountain, Nevada, U.S.A.)-the record from uranium studies: Uranium, v. 2, p. 361-386.

(NNA.900820.0268) 


\section{APPENDIX}




\begin{abstract}
APPENDIX
Compilation of fracture number, azimuth (AZI), dip, dip direction (DIP DIR), aperture, length, roughness coefficient (R.C.), and tube pitch

for pavements 100,200 , and 300 .
\end{abstract}

\title{
Symbols
}

$$
\begin{aligned}
& H=\text { Healed fracture or joint } \\
& \mathbf{O}=\text { Open fracture or joint, no aperture } \\
& \mathrm{PH}=\text { Partially healed fracture or joint } \\
& \mathrm{SW}=\text { Fracture or joint swarm } \\
& -\quad=\text { Value unobtainable } \\
& -\quad=\text { Feature not present }
\end{aligned}
$$


APPENDIX. Pavement 100, 200, and 300

\begin{tabular}{|c|c|c|c|c|c|c|c|c|}
\hline Fructure number & $\boldsymbol{N a}$ & DIP & DIP DIR & $\begin{array}{l}\text { Aperture } \\
\text { (mm) }\end{array}$ & $\begin{array}{l}\text { Length } \\
\text { (m) }\end{array}$ & R.C. & Phch & Remarks \\
\hline \multicolumn{9}{|c|}{ PAVEMENT 100} \\
\hline $\mathbf{J 1}$ & 230 & 66 & 320 & 1.02 & 1.30 & - & $6 S W$ & \\
\hline$J 2$ & 229 & 80 & 319 & 6.40 & 1.50 & 3 & 0 & \\
\hline J3.1 & 223 & 83 & 313 & 8.90 & 2.10 & 4 & $85 S W$ & \\
\hline $\mathrm{J3.2}$ & 221 & 72 & 311 & 2.40 & 5.80 & 3 & $6 S W$ & \\
\hline 34 & 226 & 73 & 316 & 0.05 & 1.70 & 4 & $6 S W$ & \\
\hline 35 & 227 & 84 & 317 & 0.05 & 3.90 & 3 & $2 S W$ & PH \\
\hline $\mathrm{J} 6$ & 214 & 75 & 304 & 34.30 & 12.40 & 1 & $8 S W$ & \\
\hline J7 & 230 & 73 & 320 & 1.27 & 1.70 & 4 & - & \\
\hline J8 & 234 & 74 & 324 & 0.05 & 4.30 & 3 & $\cdot$ & PH \\
\hline J9 & 225 & 74 & 315 & 0.64 & 2.70 & 2 & $8 S W$ & \\
\hline $\mathbf{J 1 0}$ & 227 & 72 & 317 & 0.05 & 8.00 & 2 & 10SW & PH \\
\hline $\mathbf{J 1 1}$ & 238 & 63 & 328 & 1.27 & 1.80 & $\cdot$ & $10 S W$ & PH \\
\hline$J 12$ & 235 & 68 & 325 & 5.10 & 0.80 & - & - & \\
\hline $\mathrm{J} 13$ & 232 & 79 & 322 & 0.31 & 7.40 & 1 & ssw & \\
\hline J14A & 211 & 70 & 301 & 1.20 & 2.00 & 3 & - & \\
\hline J14B & 224 & 71 & 314 & 0.81 & 4.10 & 2 & 3SW & \\
\hline $\mathrm{J} 15$ & 232 & 81 & 322 & 0.31 & 2.50 & 3 & $7 S W$ & \\
\hline J16.1 & 226 & 70 & 316 & 12.70 & 11.30 & 4 & $14 S W$ & \\
\hline $\mathrm{J} 16.2$ & 225 & 83 & 315 & 0.70 & 0.20 & - & - & \\
\hline J17.1 & 229 & 80 & 319 & 0.31 & 11.80 & 1 & $12 S W$ & \\
\hline $\mathrm{J} 17.2$ & 223 & 79 & 313 & - & 0.40 & 2 & $6 S W$ & 0 \\
\hline $\mathbf{J 1 7 . 3}$ & 220 & - & 310 & - & 0.60 & - & - & \\
\hline$J 17.4$ & 230 & 82 & 320 & 0.05 & 2.30 & 2 & 9SW & \\
\hline J18.1 & 227 & 83 & 317 & 1.02 & 11.60 & 1 & $7 S W$ & \\
\hline$J 18.2$ & 234 & 77 & 324 & 0.61 & 0.50 & - & - & \\
\hline$J 18.3$ & 235 & 85 & 325 & 3.50 & 0.40 & 3 & - & \\
\hline$J 18.4$ & 241 & 31 & 331 & 1.70 & 0.50 & - & - & PH \\
\hline$J 19$ & 235 & 89 & 325 & 0.05 & 4.00 & 3 & $7 S W$ & \\
\hline $\mathbf{J} 20$ & 228 & 85 & 318 & 0.05 & 10.10 & 3 & $13 S W$ & PH \\
\hline$J 21$ & 227 & 84 & 317 & 0.26 & 11.20 & 2 & $3 S W$ & \\
\hline$J 22$ & 231 & 86 & 321 & 0.38 & 6.40 & 2 & - & \\
\hline$J 23$ & 262 & 86 & 352 & 0.05 & 9.50 & 1 & $11 S W$ & PH \\
\hline$J 24$ & 228 & 83 & 318 & 0.13 & 4.30 & 1 & $10 S W$ & \\
\hline$J 25$ & 221 & 85 & 311 & 0.05 & 0.80 & 2 & - & \\
\hline$J 26$ & 316 & 88 & 46 & 0.76 & 4.20 & 1 & 13SE & PH \\
\hline$J 27$ & 319 & 82 & 49 & - & 3.20 & 3 & 3SE & 0 \\
\hline$J 28$ & 227 & 75 & 317 & 0.13 & 2.40 & 2 & - & PH \\
\hline$J 29$ & 233 & 65 & 323 & 0.05 & 1.50 & 4 & $6 S W$ & PH \\
\hline $\mathrm{J} 30$ & 232 & 68 & 322 & 0.05 & 0.50 & 4 & $4 S W$ & PH \\
\hline $\mathrm{J} 31.1$ & 230 & 76 & 320 & 0.05 & 0.80 & 1 & $10 S W$ & \\
\hline $\mathrm{J} 31.2$ & 239 & - & 329 & - & 0.50 & $\cdot$ & - & \\
\hline J31.3 & 239 & 83 & 329 & 2.40 & 0.60 & 2 & $4 S W$ & PH \\
\hline
\end{tabular}


APPENDIX. Pavement 100, 200, and 300 --Continued

\begin{tabular}{|c|c|c|c|c|c|c|c|c|}
\hline Fracture number & $\boldsymbol{A Z}$ & DIP & DIP DIR & $\begin{array}{l}\text { Aperture } \\
\text { (mm) }\end{array}$ & $\begin{array}{l}\text { Length } \\
\text { (m) }\end{array}$ & R.C. & Plich & Remarks \\
\hline \multicolumn{9}{|c|}{ PAVEMENT 100-Continued } \\
\hline J31.4 & 227 & 78 & 317 & 1.14 & 4.20 & 1 & 9SW & \\
\hline $\mathrm{J} 31.5$ & 230 & 76 & 320 & 3.00 & 1.50 & 3 & sSW & \\
\hline $\mathrm{J} 31.6$ & 223 & 80 & 313 & - & 1.00 & 2 & $16 S W$ & 0 \\
\hline $\mathrm{J} 32.1$ & 230 & 80 & 320 & 0.76 & 1.10 & 2 & $6 S W$ & \\
\hline $\mathrm{J} 32.2$ & 226 & 80 & 316 & 0.56 & 1.70 & 2 & - & \\
\hline J33 & 222 & 74 & 312 & 0.05 & 0.70 & 1 & - & \\
\hline $\mathrm{J} 34.1$ & 233 & 82 & 323 & 0.04 & 1.20 & 1 & $11 S W$ & \\
\hline $\mathrm{J} 34.2$ & 228 & 87 & 318 & 1.78 & 3.70 & 1 & - & \\
\hline $\mathrm{J} 34.3$ & 223 & 77 & 313 & 0.71 & 1.70 & 2 & - & \\
\hline$J 34.4$ & 225 & 89 & 315 & 6.00 & 1.45 & - & $2 S W$ & \\
\hline J35.1 & 49 & 90 & 139 & 1.91 & 3.60 & 2 & $6 S W$ & \\
\hline $\mathrm{J} 35.2$ & 233 & 84 & 323 & 1.47 & 2.10 & 1 & 9SW & \\
\hline J36.1 & 227 & 89 & 317 & 2.54 & 4.90 & 1 & $6 S W$ & \\
\hline$J 36.2$ & 230 & 88 & 320 & 2.28 & 2.20 & 2 & sSW & \\
\hline $\mathrm{J} 37$ & 226 & 82 & 316 & 0.64 & 0.40 & 2 & $3 S W$ & \\
\hline J38 & 228 & 83 & 318 & 31.80 & 0.80 & 4 & $4 S W$ & \\
\hline $\mathbf{J 3 9}$ & 221 & 83 & 311 & 1.65 & 0.60 & 4 & $3 S W$ & \\
\hline $\mathrm{J} 40.1$ & 228 & 84 & 318 & 0.64 & 2.80 & 2 & sSW & \\
\hline $\mathrm{J} 40.2$ & 225 & 84 & 315 & 1.57 & 2.30 & 2 & $10 S W$ & \\
\hline J41.1 & 231 & 83 & 321 & 0.64 & 2.30 & 1 & $10 S W$ & \\
\hline $\mathrm{J} 41.2$ & 228 & 86 & 318 & 1.47 & 2.40 & 3 & 7SW & \\
\hline$J 42$ & 311 & 81 & 41 & 14.00 & 0.30 & 3 & - & \\
\hline J43.1 & 232 & 80 & 322 & - & 0.50 & 1 & $10 S W$ & 0 \\
\hline $\mathrm{J} 43.2$ & 227 & 85 & 317 & 0.05 & 2.40 & 1 & $13 S W$ & \\
\hline J43.3 & 226 & 87 & 316 & 0.30 & 2.50 & 2 & $11 S W$ & \\
\hline$J 44$ & 287 & 87 & 17 & 0.56 & 0.50 & - & - & \\
\hline J45.1 & 225 & 81 & 315 & 1.27 & 1.30 & 4 & $12 S W$ & \\
\hline $\mathrm{J} 45.2$ & 224 & 83 & 314 & 0.43 & 1.70 & - & - & \\
\hline J45.3 & 225 & 87 & 315 & - & 0.85 & 1 & $20 S W$ & 0 \\
\hline$J 46$ & 315 & 80 & 45 & 0.05 & 0.70 & 1 & 4SE & \\
\hline J47.1 & 225 & 82 & 315 & 1.91 & 1.30 & 2 & $8 S W$ & \\
\hline$J 47.2$ & 220 & 74 & 310 & - & 0.80 & 2 & $3 S W$ & 0 \\
\hline F1 & 65 & 88 & 155 & 0.05 & 0.60 & 8 & - & \\
\hline $\mathbf{F} 2$ & 235 & 75 & 325 & 31.80 & 1.00 & 10 & -- & \\
\hline F3 & 133 & 69 & 223 & 3.20 & 2.60 & 5 & -- & \\
\hline F4 & 316 & 82 & 46 & 2.70 & 0.30 & 8 & -- & \\
\hline F5 & 286 & 87 & 16 & 2.30 & 1.90 & & - & \\
\hline F6 & 6 & 79 & 96 & 0.90 & 0.80 & - & -- & \\
\hline F7 & 225 & 80 & 315 & 0.64 & 1.30 & 11 & -- & \\
\hline F8 & 255 & 85 & 345 & 0.51 & 1.70 & 12 & -- & \\
\hline F9 & 226 & 76 & 316 & 3.80 & 2.20 & 8 & - & \\
\hline F10 & 230 & 66 & 320 & - & 2.00 & 6 & -. & 0 \\
\hline F11 & 161 & 54 & 251 & 3.10 & 1.80 & 8 & -- & \\
\hline F12 & 266 & 46 & 356 & 19.10 & 0.70 & 9 & -. & \\
\hline
\end{tabular}


APPENDIX. Pavement 100, 200, and 300 --Continued

\begin{tabular}{lllllllll}
\hline Fracture number & AZI & DIP & DIP DIR & $\begin{array}{c}\text { Aperture } \\
(\mathrm{mm})\end{array}$ & $\begin{array}{c}\text { Longth } \\
(\mathrm{m})\end{array}$ & R.C. & PItch & Remarks \\
\hline
\end{tabular}

\begin{tabular}{|c|c|c|c|c|c|c|c|c|}
\hline & & & & & & & & \\
\hline F13 & 145 & 85 & 235 & 4.60 & 1.50 & 12 & -. & \\
\hline F14 & 270 & 66 & 0 & 1.52 & 0.70 & 12 & -- & \\
\hline F15 & 9 & 68 & 99 & 7.60 & 11.80 & 5 & -- & \\
\hline F16 & 210 & 86 & 300 & 0.04 & 1.50 & 12 & -- & \\
\hline F17 & 29 & 83 & 119 & 0.15 & 1.90 & 12 & -- & \\
\hline F18 & 46 & 85 & 136 & 0.30 & 0.50 & 8 & -- & \\
\hline F19 & 43 & 73 & 133 & 2.50 & 0.40 & 13 & -- & \\
\hline F20 & 39 & 72 & 129 & 1.02 & 1.00 & 12 & -- & \\
\hline F21 & 38 & 85 & 128 & 1.02 & 1.20 & 11 & -- & \\
\hline F22 & 270 & 90 & 0 & 1.78 & 1.30 & 10 & -- & \\
\hline F23 & 10 & 61 & 100 & 2.50 & 0.70 & 10 & -- & \\
\hline F24 & 25 & 85 & 115 & 0.05 & 3.40 & 4 & - & sw \\
\hline F25 & 168 & 87 & 258 & 1.52 & 4.90 & 6 & -- & \\
\hline F26 & 345 & 75 & 75 & 8.90 & 0.80 & 8 & -- & \\
\hline F27A & 222 & 77 & 312 & 0.70 & 1.60 & 5 & -- & \\
\hline F27B & 191 & 80 & 281 & 0.46 & 1.50 & 2 & -. & \\
\hline F27C & 210 & 80 & 300 & 0.05 & 7.50 & 1 & -- & \\
\hline F28 & 45 & 86 & 135 & 0.13 & 0.50 & 14 & -. & \\
\hline F29 & 38 & 85 & 128 & 2.50 & 0.50 & 5 & -- & \\
\hline F30 & 97 & 89 & 187 & - & 0.60 & 12 & -- & 0 \\
\hline F31 & 34 & 90 & 124 & 0.05 & 0.70 & 9 & -- & \\
\hline F32 & 290 & 80 & 20 & 1.02 & 0.70 & 14 & -. & \\
\hline F33 & 155 & 85 & 245 & - & 0.50 & 14 & .- & 0 \\
\hline F34 & 74 & 78 & 164 & 6.40 & 0.50 & 10 & -- & \\
\hline F35 & 34 & 81 & 124 & 3.80 & 1.30 & 10 & -- & \\
\hline F36 & 32 & 77 & 122 & 0.05 & 0.60 & 10 & -- & \\
\hline F37 & 23 & 77 & 113 & 0.05 & 0.60 & 10 & -- & sw \\
\hline F38 & 218 & 82 & 308 & 0.10 & 2.30 & 5 & -. & sw \\
\hline F39 & 287 & 56 & 17 & 8.89 & 6.50 & 13 & -- & \\
\hline F40 & 34 & 90 & 124 & 1.91 & 6.90 & 3 & -- & \\
\hline F41 & 37 & 82 & 127 & 27.90 & 1.30 & 8 & -- & \\
\hline F42 & 32 & 67 & 122 & 8.90 & 1.20 & 9 & -- & \\
\hline F43 & 225 & 77 & 315 & 0.05 & 1.00 & 9 & -- & \\
\hline F44 & 210 & 83 & 300 & 0.05 & 1.10 & 10 & -. & \\
\hline F45 & 212 & 84 & 302 & 0.05 & 0.70 & 9 & -- & \\
\hline F46 & 208 & 75 & 298 & 0.05 & 1.00 & 10 & -- & \\
\hline F47 & 305 & 90 & 35 & 0.64 & 0.80 & 8 & -- & \\
\hline F48 & 5 & 85 & 95 & 0.13 & 13.30 & 9 & -- & SW \\
\hline F49 & 16 & 78 & 106 & 15.20 & 5.80 & 8 & -- & \\
\hline F50 & 25 & 86 & 115 & 1.02 & 1.40 & 10 & -. & sw \\
\hline F51 & 119 & 77 & 209 & 0.76 & 0.70 & 8 & -- & \\
\hline F52 & 275 & 85 & 5 & - & 0.40 & 12 & -. & $\mathrm{O}$ \\
\hline F53 & 210 & 50 & 300 & - & 1.10 & 10 & -- & $\mathrm{O}$ \\
\hline F54 & 185 & 84 & 275 & 0.10 & 4.40 & 9 & -- & sW \\
\hline
\end{tabular}


APPENDIX. Pavement 100, 200, and 300 --Continued

\begin{tabular}{|c|c|c|c|c|c|c|c|c|}
\hline Fracture number & $A Z I$ & DIP & DIP DIR & $\begin{array}{c}\text { Apenture } \\
\text { (mm) }\end{array}$ & $\begin{array}{l}\text { Length } \\
\text { (m) }\end{array}$ & R.C. & Pltch & Remarks \\
\hline \multicolumn{9}{|c|}{ PAVEMENT 100-Continued } \\
\hline F55 & 350 & 68 & 80 & 6.60 & 1.30 & 11 & -- & \\
\hline F56 & 181 & 82 & 271 & 0.36 & 1.50 & 14 & -- & \\
\hline F57 & 352 & 72 & 82 & 0.20 & 0.50 & 14 & -- & \\
\hline F58 & 184 & 88 & 274 & 2.29 & 2.40 & 9 & - & \\
\hline F59 & 133 & 76 & 223 & 3.20 & 7.90 & 10 & -- & Fault \\
\hline F60A & 150 & 86 & 240 & 0.05 & 1.70 & 10 & -- & \\
\hline F60B & 170 & 87 & 260 & 1.60 & 4.80 & 10 & -- & \\
\hline F61 & 329 & 87 & 59 & 6.40 & 1.70 & 11 & -- & \\
\hline F62 & 322 & 82 & 52 & 0.05 & 2.20 & 10 & -- & \\
\hline F63 & 330 & 56 & 60 & 0.51 & 1.20 & 11 & -- & \\
\hline F64 & 330 & 51 & 60 & 0.51 & 2.10 & 10 & -- & \\
\hline F65 & 153 & 78 & 243 & 0.20 & 3.60 & 8 & -- & SW \\
\hline F66 & 150 & 87 & 240 & 18.30 & 8.80 & 8 & - & \\
\hline F67 & 7 & 75 & 97 & 2.50 & 2.00 & 7 & -- & \\
\hline F68 & 349 & 89 & 79 & 0.05 & 0.80 & 14 & -- & \\
\hline F69 & 162 & 82 & 252 & 3.80 & 1.10 & 10 & -. & \\
\hline F70 & 168 & 65 & 258 & 1.52 & 2.30 & 9 & -- & \\
\hline F71 & 90 & 79 & 180 & 3.60 & 1.90 & 10 & -. & \\
\hline F72 & 358 & 72 & 88 & 0.05 & 1.90 & 9 & -- & \\
\hline F73 & 338 & 72 & 68 & 4.60 & 2.30 & 16 & -. & \\
\hline F74 & 11 & 89 & 101 & 1.65 & 4.70 & 123 & -. & \\
\hline F75 & 200 & 87 & 290 & 0.89 & 0.90 & 12 & - & \\
\hline F76 & 10 & 87 & 100 & 0.05 & 0.50 & 12 & .. & \\
\hline F77 & 9 & 79 & 99 & 0.05 & 0.80 & 14 & -. & \\
\hline F78 & 149 & 84 & 239 & 0.20 & 1.20 & 14 & -- & \\
\hline F79 & 200 & 83 & 290 & 0.13 & 7.80 & 9 & -. & \\
\hline F80 & 15 & 85 & 105 & 0.05 & 0.70 & 15 & -- & \\
\hline F81 & 13 & 80 & 103 & 0.12 & 0.90 & 4 & -. & \\
\hline F82 & 342 & 70 & 72 & - & 1.30 & - & -. & 0 \\
\hline F83 & 150 & 89 & 240 & - & 1.30 & 12 & -- & 0 \\
\hline F84 & 6 & 52 & 96 & 12.20 & 1.50 & 15 & -- & \\
\hline F85 & 350 & 61 & 80 & 0.04 & 2.80 & 14 & -. & SW \\
\hline F86 & 38 & 70 & 128 & 0.04 & 3.70 & 16 & -- & \\
\hline F87 & 200 & 86 & 290 & 0.08 & 3.90 & 13 & -- & SW \\
\hline F88 & 134 & 78 & 224 & 6.40 & 2.80 & 14 & -. & \\
\hline F89 & 120 & 84 & 210 & 24.10 & 1.50 & 4 & -- & \\
\hline F90 & 182 & 78 & 272 & .. & 0.50 & 11 & -- & 0 \\
\hline F91 & 175 & 65 & 265 & 0.25 & 0.80 & 6 & -. & \\
\hline F92 & 10 & 87 & 100 & 0.04 & 3.40 & 6 & -. & \\
\hline F93 & 358 & 68 & 88 & 0.25 & 5.80 & 5 & -- & \\
\hline F94 & 15 & 85 & 105 & 0.15 & 1.40 & 11 & -- & \\
\hline F95 & 325 & 87 & 55 & 0.05 & 0.60 & 10 & -- & \\
\hline F96 & 173 & 85 & 263 & 0.04 & 0.90 & 10 & -- & SW \\
\hline F97 & 165 & 81 & 255 & 10.20 & 0.80 & 8 & -- & \\
\hline
\end{tabular}


APPENDIX. Pavement 100, 200, and 300 --Continued

\begin{tabular}{|c|c|c|c|c|c|c|c|c|}
\hline Fracture number & $\mathbf{A Z I}$ & DIP & DIP DIR & $\begin{array}{l}\text { Aperture } \\
\text { (mm) }\end{array}$ & $\begin{array}{l}\text { Length } \\
\text { (m) }\end{array}$ & R.C. & Pitch & Remarks \\
\hline
\end{tabular}

PAVEMENT 100-Continued

\begin{tabular}{|c|c|c|c|c|c|c|c|}
\hline F98 & 340 & 90 & 70 & 12.70 & 0.70 & 9 & -. \\
\hline F99 & 325 & 82 & 55 & 2.80 & 1.30 & 8 & .. \\
\hline F100 & 175 & 76 & 265 & 0.51 & 2.30 & 10 & -- \\
\hline F101 & 120 & 80 & 210 & 2.50 & 1.80 & 8 & .- \\
\hline F102 & 135 & 88 & 225 & 0.13 & 0.70 & 12 & -- \\
\hline F103 & 20 & 90 & 110 & 0.41 & 1.20 & 14 & -- \\
\hline F104 & 75 & 86 & 165 & 5.10 & 0.70 & 6 & -- \\
\hline F105 & 155 & 77 & 245 & 6.40 & 3.10 & 9 & .- \\
\hline F106 & 20 & 81 & 110 & 11.40 & 3.80 & 9 & -- \\
\hline F107 & 304 & 90 & 34 & 1.52 & 0.60 & 18 & -- \\
\hline F108 & 355 & 85 & 85 & 4.60 & 0.40 & 8 & -- \\
\hline F109 & 350 & 88 & 80 & 0.05 & 2.50 & 8 & -- \\
\hline F110 & 174 & 80 & 264 & 0.38 & 0.80 & 10 & -- \\
\hline F111 & 113 & 66 & 203 & 0.25 & 1.70 & 8 & -- \\
\hline F112 & 224 & 75 & 3.14 & 0.04 & 1.20 & 6 & -. \\
\hline F113 & 105 & 71 & 195 & 1.14 & 0.80 & 12 & -- \\
\hline F114 & 322 & 86 & 52 & 2.50 & 2.60 & 14 & -. \\
\hline F115 & 357 & 82 & 87 & 0.28 & 0.70 & 9 & -- \\
\hline F116 & 76 & 79 & 166 & 0.38 & 0.80 & 10 & .. \\
\hline F117 & 322 & 88 & 52 & 0.05 & 0.50 & 13 & -- \\
\hline F118 & 326 & 82 & 56 & 0.28 & 1.20 & 12 & -- \\
\hline F119 & 325 & 87 & 55 & 33.00 & 0.80 & 10 & -- \\
\hline F120 & 135 & 59 & 225 & 21.30 & 0.80 & 13 & -- \\
\hline F121 & 352 & 90 & 82 & - & 0.60 & 9 & -- \\
\hline F122 & 262 & 82 & 352 & 2.50 & 2.10 & 10 & -- \\
\hline F123 & 70 & 75 & 160 & 0.64 & 1.20 & 10 & -- \\
\hline F124 & 75 & 81 & 165 & 8.90 & 2.70 & 5 & -- \\
\hline F125 & 176 & 80 & 266 & 0.64 & 1.70 & 4 & - \\
\hline F126 & 167 & 87 & 257 & 12.20 & 6.70 & 8 & -- \\
\hline F127 & 95 & 74 & 185 & 1.52 & 0.90 & 8 & -- \\
\hline F128 & 174 & 86 & 264 & 0.04 & 0.80 & 10 & -- \\
\hline F129 & 325 & 75 & 55 & 29.20 & 0.80 & 9 & -- \\
\hline F130 & 319 & 80 & 49 & 0.76 & 0.60 & 16 & -- \\
\hline F131 & 320 & 90 & 50 & 6.40 & 0.80 & 10 & -. \\
\hline F132 & 347 & 78 & 77 & 0.38 & 0.40 & 11 & -- \\
\hline F133 & 180 & 74 & 270 & 0.04 & 0.70 & 6 & -- \\
\hline F134 & 131 & 82 & 221 & 6.40 & 0.30 & 8 & -- \\
\hline F135 & 350 & 75 & 80 & 0.41 & 1.50 & 4 & -- \\
\hline F136 & 179 & 85 & 269 & 0.28 & 1.00 & 9 & - \\
\hline F137 & 241 & 82 & 331 & 0.25 & 0.20 & 9 & -- \\
\hline F138 & 183 & 80 & 273 & 8.40 & 0.20 & 10 & - \\
\hline F139 & 63 & 69 & 153 & 9.40 & 1.10 & 9 & -- \\
\hline F140 & 235 & 87 & 325 & 11.40 & 0.70 & 16 & -- \\
\hline F141 & 320 & 86 & 50 & - & 0.40 & 11 & - \\
\hline F142 & 63 & 79 & 153 & 3.30 & 1.50 & 12 & -. \\
\hline
\end{tabular}


APPENDIX. Pavement 100, 200, and 300 --Continued

\begin{tabular}{|c|c|c|c|c|c|c|c|c|}
\hline Fracture number & AZI & DIP & DIP DIR & $\begin{array}{c}\text { Aperture } \\
\text { (mm) }\end{array}$ & $\begin{array}{l}\text { Length } \\
\text { (m) }\end{array}$ & R.C. & Pltch & Remarks \\
\hline \multicolumn{9}{|c|}{ PAVEMENT 100-Continued } \\
\hline F143 & 85 & 79 & 175 & 1.27 & 0.40 & 7 & -- & \\
\hline F144 & 244 & 78 & 334 & 4.10 & 0.70 & 8 & -- & \\
\hline F145 & 343 & 88 & 73 & 0.08 & 0.60 & 4 & -- & \\
\hline F146 & 350 & 75 & 80 & 1.27 & 0.80 & 6 & -- & \\
\hline F147 & 169 & 84 & 259 & 1.02 & 1.80 & 8 & -- & \\
\hline F148 & 170 & 83 & 260 & 11.40 & 5.50 & 15 & .. & Fault \\
\hline F149 & 263 & 87 & 353 & 12.70 & 0.80 & 11 & -. & \\
\hline F150 & 132 & 81 & 222 & 2.29 & 2.20 & 5 & -. & \\
\hline F151 & 305 & 80 & 35 & 0.28 & 1.30 & 9 & -- & \\
\hline
\end{tabular}

\begin{tabular}{|c|c|c|c|c|c|c|c|c|}
\hline J1.1 & 221 & 76 & 311 & 0.04 & 2.40 & 1 & $14 S W$ & \\
\hline $\mathrm{J} 1.2$ & 215 & 87 & 305 & 0.56 & 10.80 & 2 & $15 S W$ & PH \\
\hline J2.1 & 216 & 76 & 306 & 0.65 & 3.00 & 1 & $13 S W$ & \\
\hline $\mathrm{J} 2.2$ & 215 & 76 & 305 & 0.04 & 16.40 & 1 & $14 S W$ & \\
\hline J3 & 212 & 63 & 302 & 0.95 & 16.60 & 4 & . & PH \\
\hline J4 & 218 & 86 & 308 & 6.40 & 18.40 & 2 & $14 S W$ & $\mathrm{PH}$ \\
\hline$J 5$ & 219 & 75 & 309 & 0.04 & 2.60 & 1 & - & PH \\
\hline$J 6$ & 165 & 79 & 255 & - & 0.50 & 3 & - & 0 \\
\hline J7 & 217 & 70 & 307 & 0.08 & 2.20 & 1 & - & \\
\hline F1 & 182 & 77 & 272 & 2.50 & 3.80 & 5 & .. & SW \\
\hline F2 & 149 & 45 & 239 & 31.80 & 3.80 & 5 & -- & \\
\hline F3 & 164 & 77 & 254 & 8.90 & 9.50 & 6 & -. & Fault \\
\hline F4 & 45 & 76 & 135 & 8.90 & 0.90 & 6 & -. & \\
\hline F5 & 170 & 84 & 260 & 2.50 & 3.90 & 4 & -- & \\
\hline F6 & 334 & 58 & 64 & 0.56 & 1.25 & 12 & -. & \\
\hline$F 7$ & 325 & 68 & 55 & 0.64 & 1.70 & 16 & - & \\
\hline F8 & 350 & 62 & 80 & 0.56 & 1.50 & 9 & -- & \\
\hline F9A & 186 & 70 & 276 & 1.52 & 3.70 & 5 & -. & \\
\hline F9B & 155 & 45 & 245 & 0.10 & 1.40 & - & -. & \\
\hline F10.1 & 145 & 58 & 235 & 0.04 & 2.90 & 8 & -- & \\
\hline F10.2 & 149 & 61 & 239 & 0.04 & 0.90 & 10 & -- & \\
\hline F11.1 & 274 & 87 & 4 & 0.08 & 2.30 & 4 & -- & \\
\hline F11.2 & 270 & 84 & 0 & 0.04 & 3.40 & 9 & -- & \\
\hline F12.1 & 105 & 81 & 195 & 0.25 & 12.60 & 9 & -- & \\
\hline F12.2 & 121 & 87 & 211 & 0.46 & 0.90 & 13 & -- & \\
\hline F13 & 143 & 57 & 233 & 0.04 & 1.10 & 10 & -- & \\
\hline F14.1 & 150 & 54 & 240 & 0.38 & 2.90 & 6 & -- & \\
\hline F14.2 & 358 & 90 & 88 & 0.27 & 1.80 & 7 & -- & \\
\hline F15 & 33 & 87 & 123 & 0.04 & 8.80 & 8 & -. & SW \\
\hline F16.1 & 280 & 75 & 370 & 8.00 & 0.20 & 10 & -. & \\
\hline F16.2 & 260 & 75 & 350 & 1.27 & 3.70 & 12 & -. & \\
\hline F17 & 228 & 72 & 318 & 0.04 & 8.10 & 11 & -- & SW \\
\hline F18 & 115 & 75 & 205 & 0.56 & 11.10 & 12 & -. & \\
\hline
\end{tabular}


APPENDIX. Pavement 100, 200, and 300 --Continued

\begin{tabular}{|c|c|c|c|c|c|c|c|c|}
\hline Fracture number & AZI & DIP & DIP DIR & $\begin{array}{l}\text { Aperture } \\
\text { (mm) }\end{array}$ & $\begin{array}{l}\text { Length } \\
\text { (m) }\end{array}$ & R.C. & Pitch & Pemarks \\
\hline \multicolumn{9}{|c|}{ PAVEMENT 200-Continued } \\
\hline F19 & 215 & 49 & 305 & - & 2.70 & 8 &.- & O \\
\hline F20 & 88 & 88 & 178 & 6.40 & 11.80 & 12 & -- & \\
\hline F21 & 155 & 87 & 245 & 0.64 & 3.00 & 12 & -- & SW \\
\hline $\mathbf{F} 22$ & 174 & 80 & 264 & 0.04 & 1.60 & 9 & $\cdots$ & \\
\hline $\mathbf{F} 23$ & 178 & 86 & 268 & 0.04 & 2.00 & 12 & -- & \\
\hline F24 & 171 & 55 & 261 & 0.04 & 2.10 & 13 & $\cdots$ & \\
\hline F25 & 178 & 78 & 268 & 0.04 & 1.50 & 8 & -- & \\
\hline F26 & 345 & 80 & 75 & 0.10 & 3.00 & 10 & -- & \\
\hline F27 & 346 & 89 & 76 & 0.51 & 3.00 & 10 & -- & \\
\hline F28 & 135 & 65 & 225 & 0.43 & 0.80 & 10 & -- & \\
\hline F29 & 270 & 86 & 0 & 12.20 & 3.70 & 10 & -- & \\
\hline F30 & 320 & 51 & 50 & - & 0.60 & 14 & -- & 0 \\
\hline F31 & 290 & 67 & 20 & 0.25 & 2.20 & 11 & - & \\
\hline F32 & 329 & 78 & 59 & - & 0.60 & 12 & -- & 0 \\
\hline F33 & 152 & 32 & 242 & - & 1.40 & 12 & -- & 0 \\
\hline F34 & 125 & 83 & 215 & 15.20 & 6.50 & 8 & -- & SW \\
\hline F35 & 95 & 80 & 185 & 3.10 & 1.20 & 12 & -- & \\
\hline F36 & 326 & 85 & 56 & 0.89 & 4.30 & 13 & -- & \\
\hline F37 & 325 & 90 & 55 & 8.90 & 2.70 & 11 & -- & \\
\hline F38 & 114 & 76 & 204 & 1.27 & 4.20 & 9 & -- & \\
\hline F39 & 150 & 87 & 240 & 0.75 & 0.90 & 14 & -- & \\
\hline F40 & 74 & 82 & 164 & - & 0.50 & 8 & -- & 0 \\
\hline F41 & 100 & 85 & 190 & 12.70 & 1.50 & 10 & -- & \\
\hline F42 & 318 & 69 & 48 & 0.10 & 1.00 & 8 & -- & \\
\hline F43 & 170 & 80 & 260 & 0.05 & 6.70 & 12 & -- & SW \\
\hline F44 & 265 & 80 & 355 & 0.28 & 4.60 & 14 & -. & \\
\hline F45 & 270 & 76 & 0 & 0.04 & 1.30 & 12 & -- & \\
\hline F46 & 182 & 88 & 272 & 1.02 & 15.70 & 12 & -- & \\
\hline F47 & 35 & 90 & 125 & 1.27 & 2.40 & 8 & -. & \\
\hline F48 & 359 & 76 & 89 & 2.50 & 3.40 & 5 & -- & \\
\hline F49 & 350 & 87 & 80 & 1.27 & 7.00 & 10 & -- & \\
\hline F50 & 161 & 79 & 251 & 0.66 & 1.30 & 9 & $-\cdot$ & \\
\hline F51 & 348 & 88 & 78 & 0.15 & 5.80 & 8 & -- & \\
\hline F52 & 154 & 75 & 244 & 1.02 & 1.50 & 7 & -- & \\
\hline F53 & 167 & 86 & 257 & 0.04 & 1.80 & 17 & -- & \\
\hline F54 & 160 & 77 & 250 & 8.90 & 7.00 & 6 & -- & \\
\hline F55 & 40 & 90 & 130 & 0.04 & 3.90 & 6 & -- & SW \\
\hline F56 & 197 & 84 & 287 & 0.04 & 15.10 & 8 & -- & SW \\
\hline F57 & 238 & 89 & 328 & 6.40 & 4.70 & 5 & -- & \\
\hline F58 & 245 & 65 & 335 & 25.40 & 2.50 & 6 & -- & \\
\hline F59 & 257 & 84 & 347 & 0.18 & 0.60 & 9 & -- & \\
\hline F60 & 64 & 90 & 154 & 6.40 & 2.30 & 8 & .. & \\
\hline F61 & 315 & 68 & 45 & 0.76 & 0.40 & 15 & -- & \\
\hline F62 & 85 & 90 & 175 & 0.20 & 0.40 & 5 & - & \\
\hline
\end{tabular}


APPENDIX. Pavement 100, 200, and 300 --Continued

\begin{tabular}{|c|c|c|c|c|c|c|c|c|}
\hline Fracture number & $\mathbf{A Z I}$ & DIP & DIP DIR & $\begin{array}{l}\text { Aporture } \\
(\mathrm{mm})\end{array}$ & $\begin{array}{l}\text { Length } \\
\text { (m) }\end{array}$ & R.C. & Plich & Romarks \\
\hline \multicolumn{9}{|c|}{ PAVEMENT 200-Continued } \\
\hline F63 & 75 & 78 & 165 & 21.60 & 0.80 & 6 & -- & \\
\hline F64 & 135 & 57 & 225 & 0.56 & 0.70 & 15 & -- & \\
\hline F65 & 46 & 90 & 136 & 12.20 & 2.30 & 6 & -- & \\
\hline F66 & 58 & 84 & 148 & 3.10 & 2.30 & 6 & -- & \\
\hline F67 & 34 & 76 & 124 & - & 1.30 & 8 & -- & O, sw \\
\hline F68 & 175 & 68 & 265 & 0.04 & 0.40 & 14 & - & \\
\hline F69 & 178 & 78 & 268 & - & 3.00 & 9 & -- & 0 \\
\hline F70A & 285 & 88 & 15 & 0.31 & 2.80 & 10 & -- & \\
\hline F70B & 265 & 84 & 355 & 0.64 & 0.70 & 8 & -- & \\
\hline F71 & 16 & 87 & 106 & 0.76 & 2.20 & 12 & -- & \\
\hline F72 & 270 & 85 & 0 & 0.13 & 0.50 & 11 & -- & \\
\hline F73 & 246 & 81 & 336 & 0.04 & 0.40 & 12 & -- & \\
\hline F74 & 25 & 90 & 115 & 0.20 & 0.35 & 12 & -- & \\
\hline F75 & 78 & 83 & 168 & 1.24 & 0.90 & 6 & -- & \\
\hline F76 & 108 & 87 & 198 & 8.90 & 7.00 & 14 & -- & \\
\hline F77 & 335 & 88 & 65 & 0.89 & 2.70 & 10 & -- & \\
\hline F78 & 345 & 90 & 75 & 0.51 & 1.30 & 11 & -- & \\
\hline F79 & 125 & 87 & 215 & 0.56 & 5.70 & 12 & -- & \\
\hline F80 & 60 & 85 & 150 & 0.04 & 1.20 & 12 & -- & \\
\hline F81 & 242 & 80 & 332 & 0.64 & 1.20 & 12 & -- & \\
\hline F82 & 100 & 74 & 190 & 0.04 & 0.90 & 12 & $\cdots$ & \\
\hline F83 & 168 & 75 & 258 & 0.04 & 3.60 & 14 & -- & \\
\hline F84 & 163 & 88 & 253 & 0.04 & 1.10 & 11 & -- & \\
\hline F85 & 167 & 76 & 257 & 0.15 & 1.20 & 6 & -- & \\
\hline F86 & 112 & 85 & 202 & 1.27 & 3.20 & 10 & - & \\
\hline F87 & 164 & 84 & 254 & 0.04 & 1.20 & 8 &.- & \\
\hline F88 & 305 & 72 & 35 & 0.04 & 2.50 & 13 & -- & \\
\hline F89 & 61 & 90 & 151 & 1.00 & 2.30 & 10 & - & \\
\hline \multicolumn{9}{|c|}{ PAVEMENT 300} \\
\hline J1 & 315 & 83 & 45 & 3.10 & 5.30 & 4 & 8SE & \\
\hline $\mathrm{J} 2$ & 135 & 82 & 225 & 9.40 & 1.30 & 2 & 28SE & \\
\hline J3.1 & 204 & 77 & 294 & 8.90 & 2.00 & 2 & $14 S W$ & \\
\hline $\mathrm{J} 3.2$ & 210 & 73 & 300 & - & 0.40 & 2 & $15 S W$ & 0 \\
\hline J4 & 317 & 81 & 47 & 8.90 & 7.40 & 1 & 18SE & \\
\hline J5 & 321 & 78 & 51 & 12.20 & 5.40 & 3 & 19SE & \\
\hline J6 & 179 & 79 & 269 & 0.04 & 0.70 & - & - & \\
\hline 37 & 211 & 79 & 301 & 2.50 & 2.20 & 2 & $14 S W$ & \\
\hline$J 8$ & 310 & 85 & 40 & 0.04 & 0.40 & 3 & 14SE & \\
\hline J9A & 309 & 82 & 39 & 0.04 & 2.70 & 1 & IOSE & PH \\
\hline J9B & 320 & 80 & 50 & 0.04 & 3.70 & 4 & 20SE & \\
\hline $\mathrm{J} 10$ & 331 & 74 & 61 & 12.20 & 0.80 & 3 & 27SE & \\
\hline J11 & 314 & 84 & 44 & 15.00 & 5.00 & 1 & $12 \mathrm{SE}$ & $\mathrm{O}, \mathrm{PH}$ \\
\hline $\mathrm{J} 12$ & 316 & 70 & 46 & 8.90 & 0.50 & 3 & 20SE & \\
\hline
\end{tabular}


APPENDIX. Pavement 100, 200, and 300 --Continued

\begin{tabular}{|c|c|c|c|c|c|c|c|c|}
\hline Fracture number & $\mathbf{A x}$ & DIP & DIP DIR & $\begin{array}{l}\text { Aperture } \\
\text { (mm) }\end{array}$ & $\begin{array}{l}\text { Length } \\
\text { (m) }\end{array}$ & P.C. & Pltch & Romarks \\
\hline \multicolumn{9}{|c|}{ PAVEMENT 300-Continued } \\
\hline$J 13$ & 347 & 81 & 77 & 4.10 & 0.70 & - & 22SE & \\
\hline$J 14$ & 307 & 80 & 37 & 10.20 & 0.50 & 3 & 37SE & \\
\hline$J 15$ & 145 & 82 & 235 & 3.10 & 8.80 & - & SOSE & \\
\hline $\mathrm{J} 16$ & 201 & 81 & 291 & 0.04 & 1.30 & 4 & $15 S W$ & PH \\
\hline J17A & 312 & 86 & 42 & 0.04 & 1.25 & 1 & 26SE & PH \\
\hline $\mathrm{J17B}$ & 326 & 87 & 56 & 0.50 & 6.25 & 2 & 43SE & \\
\hline $\mathrm{J} 18$ & 319 & 88 & 49 & 0.04 & 8.20 & - & 18SE & $11 \mathrm{SE}$ \\
\hline J19 & 224 & 71 & 314 & 0.00 & 0.80 & 2 & 18SE & $H$ \\
\hline $\mathrm{J} 20$ & 330 & 84 & 60 & 0.04 & 7.80 & 2 & 38SE & \\
\hline $\mathrm{J} 21$ & 223 & 85 & 313 & 19.10 & 0.30 & 2 & $7 S W$ & \\
\hline$J 22$ & 317 & 80 & 47 & 0.00 & 0.30 & - & - & $\mathbf{H}$ \\
\hline $\mathbf{J} 23$ & 317 & 87 & 47 & 2.41 & 2.30 & 2 & 10SE & \\
\hline$J 24$ & 321 & 78 & 51 & 1.91 & 4.80 & 1 & 26SE & \\
\hline $\mathrm{J} 25$ & 220 & 78 & 310 & 0.13 & 2.70 & 1 & $25 S W$ & \\
\hline $\mathbf{J} 26$ & 317 & 83 & 47 & 0.04 & 13.10 & 3 & 21SE & 46SE, PH \\
\hline$J 27$ & 345 & 85 & 75 & 0.00 & 6.50 & - & 23SE & $\mathbf{H}$ \\
\hline $\mathrm{J} 28$ & 312 & 88 & 42 & 0.13 & 0.90 & 1 & $36 S E$ & \\
\hline $\mathrm{J} 29$ & 216 & 72 & 306 & 0.04 & 1.00 & 1 & - & PH \\
\hline J30A & 311 & 83 & 41 & 0.04 & 2.20 & 1 & 33SE & \\
\hline J30B & 325 & 79 & 55 & 0.04 & 9.75 & 2 & 34SE & \\
\hline J31 & 35 & 90 & 125 & 7.90 & 0.30 & 4 & $41 S W$ & \\
\hline $\mathbf{J} 32$ & 355 & 78 & 85 & 0.05 & 2.50 & 2 & $17 \mathrm{SE}$ & \\
\hline $\mathbf{J 3 3}$ & 320 & 78 & 50 & 9.10 & 1.60 & 2 & 48SE & \\
\hline J34 & 0 & 76 & 90 & 0.51 & 3.00 & - & - & PH \\
\hline $\mathrm{J} 35$ & 165 & 78 & 255 & 0.51 & 1.40 & 2 & 38SE & \\
\hline J37 & 324 & 85 & 54 & 0.25 & 3.20 & 1 & 40SE & \\
\hline$J 36 B$ & 301 & 86 & 31 & 0.31 & 2.50 & 1 & 43SE & PH \\
\hline$J 37$ & 240 & 86 & 330 & - & 0.30 & 2 & 17SE & 0 \\
\hline $\mathbf{J 3 8}$ & 330 & 86 & 60 & 0.76 & 1.40 & 2 & 46SE & \\
\hline J39 & 219 & 77 & 309 & 0.36 & 3.20 & 2 & 19SE & $11 S w$ \\
\hline $\mathrm{J} 40$ & 320 & 78 & 50 & 2.03 & 0.70 & 3 & 40SE & \\
\hline $\mathrm{J} 41$ & 320 & 82 & 50 & 0.08 & 0.50 & 3 & 51SE & \\
\hline $\mathrm{J} 42$ & 310 & 81 & 40 & 0.76 & 0.50 & 4 & $\cdot$ & \\
\hline $\mathrm{J} 43$ & 220 & 76 & 310 & 0.04 & 1.40 & 3 & - & \\
\hline J44 & 331 & 87 & 61 & - & 2.60 & 1 & 19SE & $0,29 S E$ \\
\hline J45 & 45 & 90 & 135 & - & 1.40 & 4 & 17SE & 0 \\
\hline J46.1 & 210 & 71 & 300 & - & 1.90 & 1 & $47 \mathrm{SW}$ & 0 \\
\hline $\mathrm{J} 46.2$ & 205 & 76 & 295 & - & 0.60 & 2 & $48 S W$ & 0 \\
\hline J47 & 204 & 76 & 294 & 3.30 & 1.50 & - & $17 \mathrm{SW}$ & \\
\hline F1 & 200 & 70 & 290 & 0.04 & 0.80 & 14 & .. & \\
\hline $\mathbf{F} 2$ & 46 & 81 & 136 & 0.64 & 1.90 & 9 & -. & \\
\hline F3 & 45 & 90 & 135 & 0.25 & 0.50 & 7 & - & \\
\hline F4 & 356 & 90 & 86 & 0.04 & 0.50 & 7 & -. & \\
\hline F5 & 173 & 75 & 263 & 0.38 & 1.30 & 9 & - & \\
\hline
\end{tabular}


APPENDIX. Pavement 100, 200, and 300 --Continued

\begin{tabular}{|c|c|c|c|c|c|c|c|c|}
\hline Frecturs number & $\boldsymbol{A x}$ & DIP & DIP DIR & $\begin{array}{l}\text { Aporture } \\
\text { (mm) }\end{array}$ & $\begin{array}{l}\text { Length } \\
\text { (m) }\end{array}$ & R.C. & Plich & Remarks \\
\hline \multicolumn{9}{|c|}{ PAVEMENT 300-Continued } \\
\hline F6 & 49 & 56 & 139 & 0.76 & 0.50 & 10 & -- & \\
\hline F7 & 178 & 71 & 268 & 0.04 & 1.40 & 10 & .. & \\
\hline F8 & 62 & 90 & 152 & 3.20 & 4.30 & 6 & 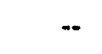 & \\
\hline F9A & 190 & 65 & 280 & 0.76 & 1.10 & 14 & $\cdots$ & \\
\hline F9B & 154 & 60 & 244 & - & 1.50 & - & -. & 0 \\
\hline F10 & 187 & 67 & 277 & 10.70 & 0.90 & 12 & -. & \\
\hline F11 & 160 & 82 & 250 & 6.40 & 2.70 & 11 & -- & \\
\hline $\mathbf{F} 12$ & 171 & 79 & 261 & 12.70 & 1.70 & 9 & $\cdots$ & \\
\hline F13 & 135 & 58 & 225 & 0.04 & 1.20 & 7 & $\cdots$ & \\
\hline F14 & 50 & 76 & 140 & 1.40 & 1.20 & 7 & -. & \\
\hline F15 & 243 & 74 & 333 & $\cdot$ & 1.30 & 8 & -. & 0 \\
\hline F16 & 235 & 84 & 325 & - & 1.30 & 6 & $-\cdot$ & 0 \\
\hline $\mathbf{F} 17$ & 331 & 90 & 61 & - & 0.90 & 6 & -- & $\mathbf{o}$ \\
\hline F18 & 339 & 90 & 69 & 1.27 & 5.60 & 10 & $\cdots$ & SW \\
\hline F19 & 194 & 64 & 284 & 1.30 & 0.40 & 12 & .. & \\
\hline F20 & 187 & 59 & 277 & 1.50 & 0.90 & $\cdot$ & -- & \\
\hline $\mathbf{F 2 1}$ & 187 & 80 & 277 & 0.89 & 0.40 & 13 & -- & \\
\hline $\mathbf{F 2 2}$ & 193 & 72 & 283 & - & 0.60 & 8 & .. & 0 \\
\hline $\mathbf{F} 23$ & 205 & 74 & 295 & - & 0.30 & 8 & -. & 0 \\
\hline F24 & 206 & 85 & 296 & 2.46 & 0.30 & 8 & -- & \\
\hline F25 & 211 & 79 & 301 & 1.27 & 0.80 & 12 & $\cdot$ & \\
\hline F26 & 43 & 90 & 133 & 0.05 & 0.30 & 12 & -. & \\
\hline F27 & 325 & 90 & 55 & - & 0.60 & 6 & -. & 0 \\
\hline F28 & 143 & 84 & 233 & - & 0.40 & 6 & -- & 0 \\
\hline F29 & 136 & 79 & 226 & 0.89 & 0.50 & 7 & $\cdots$ & \\
\hline F30 & 314 & 90 & 44 & 1.70 & 0.70 & 7 & -. & \\
\hline F31 & 335 & 90 & 65 & 1.40 & 2.50 & 12 & - & \\
\hline F32A & 234 & 72 & 324 & 0.51 & 1.10 & 11 & $\cdots$ & \\
\hline F32B & 332 & 87 & 62 & 0.38 & 0.60 & - & -- & \\
\hline F33 & 155 & 78 & 245 & 6.40 & 2.70 & 6 & -- & \\
\hline F34 & 76 & 77 & 166 & 0.76 & 1.20 & 8 & -- & \\
\hline F35 & 20 & 90 & 110 & 6.40 & 0.80 & 8 & -- & \\
\hline F36 & 347 & 90 & 77 & 0.04 & 0.90 & 9 & $-\cdot$ & SW \\
\hline F37 & 155 & 75 & 245 & 2.80 & 1.10 & 4 & -. & \\
\hline F38 & 161 & 89 & 251 & - & 1.70 & 5 & -- & 0 \\
\hline F39 & 114 & 67 & 204 & 0.38 & 0.60 & 10 & -. & \\
\hline F40 & 198 & 80 & 288 & 5.10 & 1.70 & 5 & $\cdots$ & \\
\hline F41 & 60 & 77 & 150 & 6.40 & 1.80 & 12 & -- & \\
\hline F42 & 25 & 81 & 115 & - & 2.10 & 13 & -- & 0 \\
\hline F43 & 155 & 44 & 245 & - & 1.70 & 9 & -- & 0 \\
\hline F44 & 69 & 78 & 159 & 1.47 & 1.60 & 12 & -- & \\
\hline F45 & 57 & 83 & 147 & 0.89 & 1.50 & 14 & $\cdots$ & \\
\hline F46 & 151 & 85 & 241 & 2.29 & 3.80 & 6 & $\cdots$ & \\
\hline F47 & 39 & 54 & 129 & 3.80 & 2.40 & 13 & -- & \\
\hline
\end{tabular}

58 Charecterizing Frectured Rock for Fluld-flow, Geomechanical, and Paleostress Modeling: Methods and Preliminary Results from Yucca Mountain, Novada 
APPENDIX. Pavement 100, 200, and 300 ..Continued

\begin{tabular}{|c|c|c|c|c|c|c|c|c|}
\hline Fracture number & $\boldsymbol{N} \mathbf{x}$ & DIP & DIP DIA & $\begin{array}{l}\text { Apenturs } \\
\text { (mm) }\end{array}$ & $\begin{array}{l}\text { Length } \\
\text { (m) }\end{array}$ & A.C. & Pltch & Rom \\
\hline \multicolumn{9}{|c|}{ PAVEMENT 300-Continued } \\
\hline F48 & 140 & 49 & 230 & - & 0.90 & 9 & .. & 0 \\
\hline F49 & 147 & 53 & 237 & 1.02 & 1.70 & 5 & .. & \\
\hline F50 & 149 & 70 & 239 & 0.04 & 0.80 & 9 & -- & \\
\hline F51 & 351 & 85 & 81 & 0.38 & 0.80 & 9 & .. & \\
\hline F52 & 358 & 84 & 88 & 0.64 & 2.30 & 8 & -. & sw \\
\hline F53 & 235 & 70 & 325 & 1.91 & 0.70 & 13 & .. & \\
\hline F54 & 278 & 81 & 8 & 0.25 & 0.60 & 14 & $\cdots$ & \\
\hline F55 & 124 & 59 & 214 & 0.89 & 1.20 & 6 &. & \\
\hline F56 & 179 & 80 & 269 & 6.40 & 0.80 & 14 & $\cdots$ & \\
\hline F57 & 250 & 86 & 340 & 2.34 & 0.80 & 10 & .. & \\
\hline F58 & 210 & 66 & 300 & 3.20 & 1.30 & 10 & .. & \\
\hline F59 & 45 & 55 & 135 & 2.03 & 0.80 & 14 & $\cdots$ & \\
\hline $\mathbf{F} 60$ & 17 & 84 & 107 & 1.52 & 0.70 & 10 & -- & \\
\hline F61 & 218 & 82 & 308 & 1.78 & 1.30 & 11 & $\cdots$ & \\
\hline F62 & 320 & 90 & 50 & 2.50 & 3.60 & 11 & -. & \\
\hline P63 & 50 & 89 & 140 & - & 0.50 & 12 & .- & 0 \\
\hline F64 & 148 & 56 & 238 & 1.65 & 3.30 & 6 & -. & \\
\hline F65 & 331 & 90 & 61 & - & 0.80 & 12 & -- & 0 \\
\hline F66 & 45 & 84 & 135 & 0.25 & 0.70 & 13 & -. & \\
\hline F67 & 348 & 87 & 78 & $\cdot$ & 0.80 & 13 & $\cdots$ & 0 \\
\hline F68 & 38 & 90 & 128 & 0.25 & 1.20 & 17 & - & \\
\hline F69 & 210 & 85 & 300 & 0.36 & 1.20 & 9 & $\cdots$ & \\
\hline F70 & 19 & 76 & 109 & 0.56 & 0.50 & 14 & - & \\
\hline F71 & 35 & 90 & 125 & 6.40 & 1.60 & 16 & - & \\
\hline F72 & 133 & 40 & 223 & - & 5.50 & 9 & -. & 0 \\
\hline F73 & 70 & 86 & 160 & 31.80 & 0.80 & 10 & .. & \\
\hline F74 & 20 & 86 & 110 & 0.25 & 0.90 & 16 & $\cdots$ & \\
\hline F75 & 174 & 81 & 264 & 1.27 & 1.30 & 11 & $\cdots$ & \\
\hline F76 & 230 & 88 & 320 & 6.40 & 1.40 & 14 & -- & \\
\hline F77 & 150 & 79 & 240 & 0.64 & 1.90 & 12 & $\cdots$ & SW \\
\hline F78 & 11 & 63 & 101 & 0.20 & 0.60 & 16 & $\cdots$ & \\
\hline F79 & 326 & 84 & 56 & 0.04 & 0.60 & 4 & .. & \\
\hline F80 & 322 & 83 & 52 & 0.04 & 0.50 & 6 & -. & \\
\hline F81 & 320 & 78 & 50 & 0.25 & 0.80 & 11 & -. & \\
\hline F82 & 29 & 84 & 119 & 0.94 & 1.10 & 13 & -- & SW \\
\hline F83 & 330 & 90 & 60 & 0.76 & 2.50 & 4 & -. & \\
\hline F84 & 20 & 90 & 110 & 0.25 & 1.80 & 17 & -. & \\
\hline F85 & 239 & 82 & 329 & 0.04 & 2.50 & 16 & -- & \\
\hline F86 & 59 & 68 & 149 & 0.64 & 0.70 & 14 & -. & \\
\hline F87 & 53 & 68 & 143 & 0.13 & 1.00 & 12 & -- & \\
\hline F88 & 35 & 90 & 125 & 6.40 & 3.60 & 14 &.- & \\
\hline F89 & 28 & 78 & 118 & 6.40 & 2.00 & 15 & -. & \\
\hline F90 & 218 & 75 & 308 & 8.90 & 2.90 & 16 & -. & \\
\hline F91A & 55 & 90 & 145 & 2.41 & 1.20 & 16 & - & \\
\hline
\end{tabular}


APPENDIX. Pavement 100, 200, and 300 -.Continued

\begin{tabular}{|c|c|c|c|c|c|c|c|c|}
\hline Precture number & $\boldsymbol{A} \boldsymbol{Z}$ & DIP & DIP DIR & $\begin{array}{l}\text { Aperture } \\
\text { (mm) }\end{array}$ & $\begin{array}{l}\text { Length } \\
\text { (m) }\end{array}$ & R.C. & Phoh & Remarke \\
\hline \multicolumn{9}{|c|}{ PAVEMENT 300-Continued } \\
\hline F91B & 212 & 82 & 302 & - & 1.50 & - &.$\cdot$ & 0 \\
\hline F92 & 50 & 82 & 140 & 22.90 & 0.60 & 16 & .. & \\
\hline F93 & 339 & 76 & 69 & 6.40 & 1.30 & 12 &.. & \\
\hline F94 & 15 & 78 & 105 & 0.13 & 2.30 & 16 & .. & sw \\
\hline P95 & 57 & 80 & 147 & 0.64 & 0.80 & 9 & .. & \\
\hline P96 & 15 & 57 & 105 & 3.20 & 1.10 & 10 &.. & \\
\hline F97 & 132 & 86 & 222 & 0.51 & 4.50 & 9 & $\cdots$ & \\
\hline F98 & 322 & 80 & 52 & 1.52 & 2.80 & 9 &.. & \\
\hline P99 & 355 & 90 & 85 & 1.65 & 2.50 & 8 & .- & \\
\hline F100 & 180 & 89 & 270 & 3.10 & 2.70 & 6 & .. & \\
\hline F101 & 358 & 90 & 88 & 2.50 & 1.00 & 13 & -. & sw \\
\hline F102 & 145 & 47 & 235 & 0.64 & 3.40 & 8 & .. & \\
\hline F103 & 192 & 83 & 282 & 1.02 & 2.30 & 6 & -- & SW \\
\hline F104 & 45 & 90 & 135 & $\cdot$ & 1.20 & 17 & -. & 0 \\
\hline P10s & 208 & 74 & 298 & 0.38 & 0.90 & 14 & -• & \\
\hline F106 & 300 & 90 & 30 & 0.53 & 1.30 & 10 & .- & \\
\hline F107 & 342 & 90 & 72 & 0.51 & 0.70 & 6 & -. & \\
\hline F108 & 348 & 90 & 78 & • & 0.90 & 12 & -. & 0 \\
\hline P109 & 156 & 85 & 246 & 0.04 & 0.60 & 5 & -. & \\
\hline F110 & 340 & 90 & 70 & 0.89 & 0.50 & 9 & -. & \\
\hline F111 & 139 & 50 & 229 & 0.64 & 1.90 & 5 & $\cdots$ & \\
\hline F112 & 245 & 87 & 335 & 38.10 & 2.30 & 10 & .. & \\
\hline F113 & 330 & 81 & 60 & 0.04 & 13.70 & 6 & $\cdots$ & SW \\
\hline F114 & 198 & 68 & 288 & - & 0.70 & 5 & .. & 0 \\
\hline F11s & 29 & 80 & 119 & 0.04 & 0.80 & 8 &. & \\
\hline F116 & 196 & 79 & 286 & 21.10 & 1.30 & 10 & -- & \\
\hline F117 & 327 & 90 & 57 & - & 0.40 & 10 & .. & 0 \\
\hline F118 & 161 & 77 & 251 & - & 0.70 & 5 & .. & 0 \\
\hline F119 & 124 & 88 & 214 & 5.30 & 3.10 & 6 & -. & \\
\hline F120 & 33 & 45 & 123 & 50.80 & 1.80 & 10 & -- & \\
\hline F121 & 118 & 80 & 208 & 0.38 & 1.60 & 10 & -. & sw \\
\hline F122 & 322 & 80 & 52 & - & 1.50 & 5 & -- & 0 \\
\hline F123 & 329 & 83 & 59 & 0.13 & 13.00 & 5 & -. & SW \\
\hline F124 & 324 & 81 & 54 & 0.13 & 1.60 & 9 & $\cdots$ & \\
\hline F125A & 334 & 74 & 64 & 0.43 & 1.50 & 8 & -. & \\
\hline F125B & 320 & 79 & 50 & 0.28 & 1.90 & 10 & -- & \\
\hline F126 & 330 & 84 & 60 & 1.52 & 3.00 & 12 & -- & \\
\hline F127 & 322 & 88 & 52 & 0.25 & 1.10 & 12 & - & \\
\hline F128 & 311 & 75 & 41 & 0.56 & 1.20 & 9 & - & \\
\hline F129 & 0 & 70 & 90 & 0.25 & 2.30 & 10 & -. & \\
\hline$F 130$ & 340 & 70 & 70 & 0.76 & 1.80 & 12 & $-\cdot$ & \\
\hline $\mathbf{F} 131$ & 318 & 74 & 48 & 0.04 & 0.50 & 9 & -- & \\
\hline F132 & 320 & 90 & 50 & 0.38 & 4.10 & 14 & -- & \\
\hline F133 & 351 & 90 & 81 & 0.20 & 0.90 & 8 & .. & \\
\hline
\end{tabular}


APPENDIX. Pavement 100, 200, and 300 ..-Continued

\begin{tabular}{|c|c|c|c|c|c|c|c|c|}
\hline Presture number & $\boldsymbol{N a}$ & DAP & DIP DIR & $\begin{array}{l}\text { Aperture } \\
\text { (mm) }\end{array}$ & $\begin{array}{l}\text { Length } \\
\text { (m) }\end{array}$ & A.c. & Plteh & Pemurke \\
\hline
\end{tabular}

\section{PAVEMENT 300-Continued}

\begin{tabular}{|c|c|c|c|c|c|c|c|c|}
\hline F134 & 232 & 77 & 322 & 46.00 & 0.40 & 14 & .. & \\
\hline F135 & 330 & 79 & 60 & 0.04 & 3.20 & 13 & .. & \\
\hline P136 & 130 & 76 & 220 & . & 3.80 & 5 & .. & $O$, Fault \\
\hline F137 & 120 & 77 & 210 & 1.02 & 5.70 & 13 & -• & \\
\hline P138 & 150 & 82 & 240 & 0.04 & 0.90 & 14 & .. & \\
\hline F139 & 143 & 63 & 233 & 0.20 & 1.40 & 10 & .. & \\
\hline P140 & 323 & 83 & 53 & 0.64 & 1.40 & 10 & .. & \\
\hline F141 & 330 & 90 & 60 & 0.04 & 5.00 & 7 & .. & \\
\hline F142 & 321 & 87 & 51 & 0.04 & 2.30 & 9 & .. & \\
\hline F143 & 327 & 89 & 57 & 0.91 & 1.00 & 14 & .. & \\
\hline F144 & 329 & 80 & 59 & 0.04 & 5.00 & 12 & -. & \\
\hline F145 & 326 & 82 & 56 & 0.25 & 3.50 & 9 & -. & SW \\
\hline F146 & 324 & 83 & 54 & 0.38 & 2.40 & 8 & .. & \\
\hline F147 & 60 & 79 & 150 & 6.40 & 3.00 & 17 & -. & \\
\hline F148 & 150 & 81 & 240 & 0.41 & 0.90 & 9 & -. & \\
\hline F149 & 305 & 90 & 35 & 0.36 & 0.80 & 13 & -. & \\
\hline F150 & 169 & 75 & 259 & 0.18 & 0.50 & 14 & .. & \\
\hline Fis! & 174 & 80 & 264 & 0.81 & 1.10 & 13 & -. & \\
\hline F152 & 53 & 90 & 143 & 1.52 & 0.80 & 12 & .. & \\
\hline F153 & 37 & 85 & 127 & 0.76 & 1.30 & 14 & -. & \\
\hline F154 & 249 & 75 & 339 & 0.51 & 0.80 & 12 & -. & \\
\hline F155 & 80 & 63 & 170 & 0.20 & 1.20 & 13 & -. & \\
\hline F156 & 304 & 84 & 34 & 0.86 & 6.50 & 4 & .. & \\
\hline F157 & 300 & 90 & 30 & 0.81 & 2.70 & 9 & .. & \\
\hline F158 & 40 & 90 & 130 & 0.25 & 0.50 & 16 & -. & \\
\hline F159 & 43 & 80 & 133 & 0.04 & 0.60 & 5 & -. & \\
\hline F160 & 31 & 90 & 121 & 0.04 & 0.30 & 5 & -• & \\
\hline F161 & 225 & 68 & 315 & 0.25 & 0.80 & 12 & -. & \\
\hline F162 & 215 & 75 & 305 & 0.20 & 1.20 & 12 & .. & \\
\hline F163 & 198 & 88 & 288 & 0.13 & 0.60 & 10 & .- & \\
\hline F164 & 331 & 85 & 61 & - & 3.70 & 12 & .. & 0 \\
\hline F165 & 156 & 81 & 246 & - & 2.00 & 4 & .. & 0 \\
\hline F166 & 151 & 79 & 241 & 25.40 & 7.20 & 6 & .. & \\
\hline F167 & 201 & 70 & 291 & - & 1.50 & 6 & .- & 0 \\
\hline P168 & 305 & 90 & 35 & 0.04 & 0.40 & 14 & .. & \\
\hline F169 & 169 & 69 & 259 & 0.15 & 1.60 & 9 & .. & \\
\hline F170 & 210 & 72 & 300 & 5.80 & 0.40 & 8 & -. & \\
\hline F171 & 94 & 85 & 184 & 0.25 & 3.90 & 18 & .. & sW \\
\hline F172 & 354 & 60 & 84 & 0.23 & 1.00 & 15 & .. & \\
\hline F173 & 2 & 73 & 92 & 0.25 & 0.80 & 14 & .. & \\
\hline F174 & 355 & 64 & 85 & 0.08 & 2.80 & 10 & .. & \\
\hline F175 & 345 & 90 & 75 & 0.04 & 1.10 & 18 & .- & \\
\hline F176 & 2 & 72 & 92 & 0.04 & 1.20 & 10 & .. & \\
\hline F177 & 5 & 66 & 95 & 0.13 & 1.30 & 18 & .. & \\
\hline
\end{tabular}


APPENDIX. Pavement 100, 200, and 300 --Continued

\begin{tabular}{|c|c|c|c|c|c|c|c|c|}
\hline Frecture number & ard & DIP & DIP DIA & $\begin{array}{c}\text { Aporture } \\
\text { (mm) }\end{array}$ & $\begin{array}{c}\text { Longth } \\
\text { (m) }\end{array}$ & R.C. & Plteh & Remarks \\
\hline \multicolumn{9}{|c|}{ PAVEMENT 300-Continued } \\
\hline F178 & 350 & 90 & 80 & 0.04 & 3.60 & 12 & -. & sw \\
\hline F179 & 3 & 83 & 93 & 0.38 & 3.50 & 8 & .. & \\
\hline F180 & 0 & 90 & 90 & 0.04 & 6.70 & 8 & .- & \\
\hline F181 & 155 & 67 & 245 & 0.04 & 2.10 & 14 &.. & \\
\hline F182 & 25 & 90 & 115 & 0.04 & 0.70 & 12 & •. & \\
\hline F183 & 55 & 78 & 145 & 0.05 & 1.30 & 12 &.. & \\
\hline F184 & 357 & 87 & 87 & 0.31 & 2.40 & 13 &.- & \\
\hline F185 & 298 & 90 & 28 & 0.20 & 2.40 & 12 & -- & \\
\hline F186 & 60 & 90 & 150 & 0.46 & 1.20 & 11 & .. & \\
\hline F187 & 180 & 89 & 270 & 0.05 & 1.70 & 12 & -. & sW \\
\hline F188 & 125 & 71 & 215 & 0.04 & 2.90 & 10 & -. & \\
\hline F189 & 304 & 90 & 34 & - & 2.00 & 8 & .. & 0 \\
\hline F190 & 240 & 78 & 330 & 30.50 & 1.70 & 8 & .. & \\
\hline F191 & 90 & 90 & 180 & 0.04 & 2.40 & 10 & -. & \\
\hline F192 & 280 & 90 & 10 & 0.05 & 4.90 & 6 & .- & \\
\hline F193 & 120 & 74 & 210 & 0.51 & 3.70 & 12 & .- & \\
\hline F194 & 45 & 90 & 135 & 0.08 & 3.10 & 13 & -. & \\
\hline F195 & 155 & 70 & 245 & 0.08 & 2.30 & 9 & .. & \\
\hline F196 & 11 & 80 & 101 & 0.05 & 1.60 & 9 & -- & \\
\hline F197 & 13 & 81 & 103 & 0.04 & 0.90 & - & .- & \\
\hline F198 & 25 & 85 & 115 & 0.05 & 2.20 & 12 & -. & \\
\hline P199 & 40 & 65 & 130 & 0.97 & 1.40 & 14 & -- & \\
\hline F200 & 164 & 78 & 254 & 0.10 & 1.30 & 8 & -. & \\
\hline
\end{tabular}

HU S GOVERNMENT PRINTING OFFICE 1994.0.575.003

62 Charectorlzing Fractured Rock for Fluld-flow, Geomechanical, and Paleostrese Modellng: Mothods and Preliminary Resulte from Yucea Mountain, Novada 


\section{U.S. DEPARTMENT OF THE INTERIOR}

U.S. GEOLOGICAL SURVEY

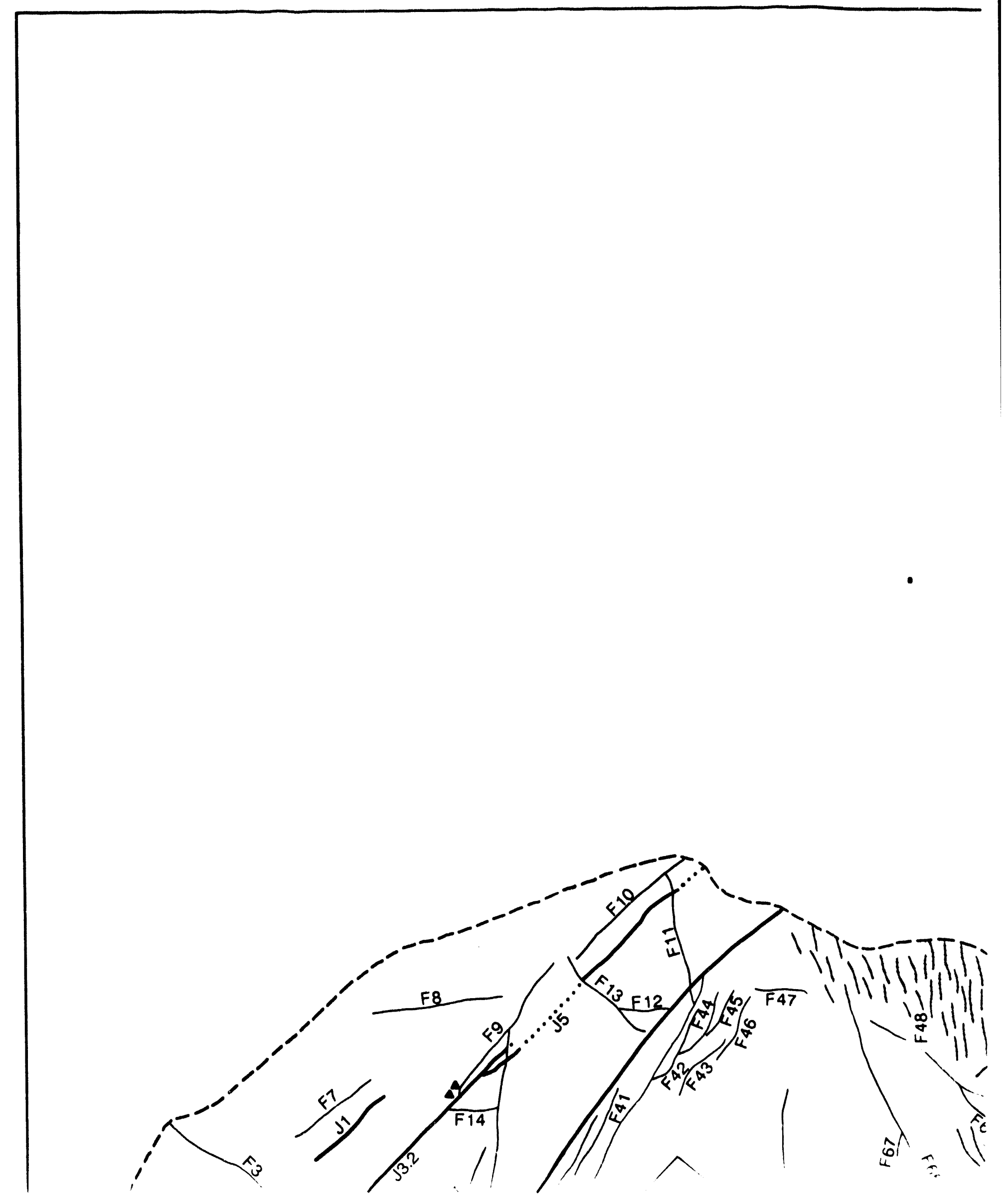





\section{EXPLANATION}

Open joint with tubular structures, dashed where inferred, dotted where healed; joint number keyed to appendix

Open fracture or fault without tubular structures, dashed where inferred, dotted where weathered; arrows showing direction of displacement on faults;

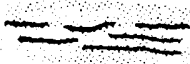
fracture member keyed to appendix

Intense swarming of fractures less than $20 \mathrm{~cm}$ long

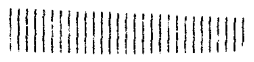

Shallow dipping joint or fracture surface.

Area of anomalously high infiltration.

- Vapor-phase silica mineralization along joint or fracture.

- Calcrete in joint, fracture, or fault zone.

- - - - - Pavement boundary.

T

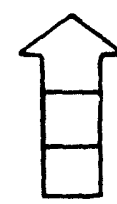

True-north arrow
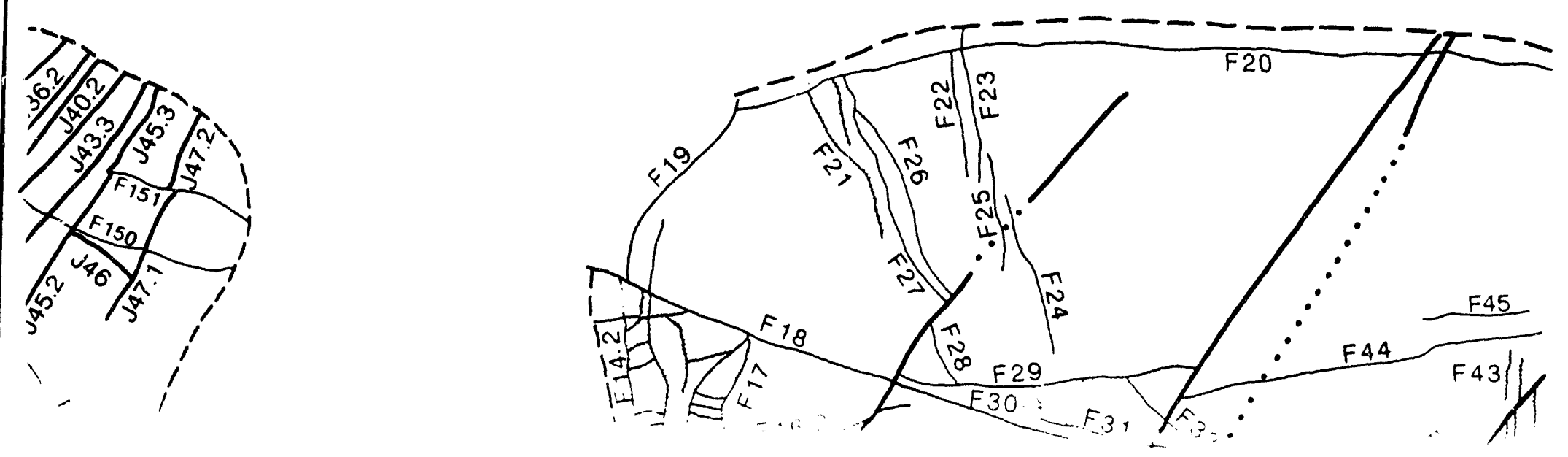


\section{speration with}

ent of Energy

\section{INDEX}
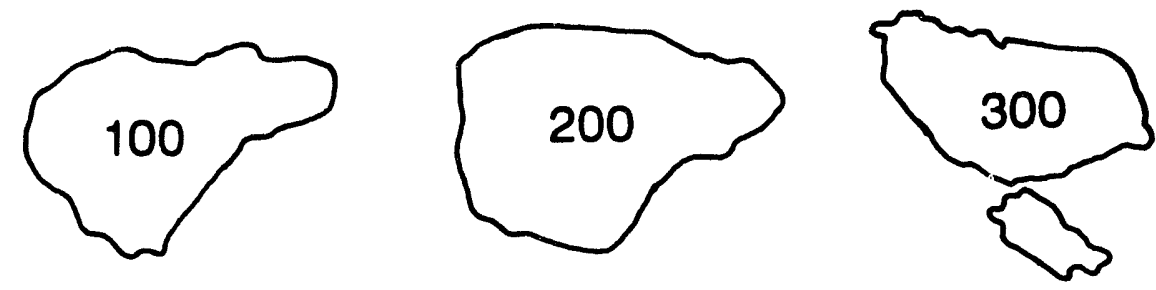

Pavements shown at same scale

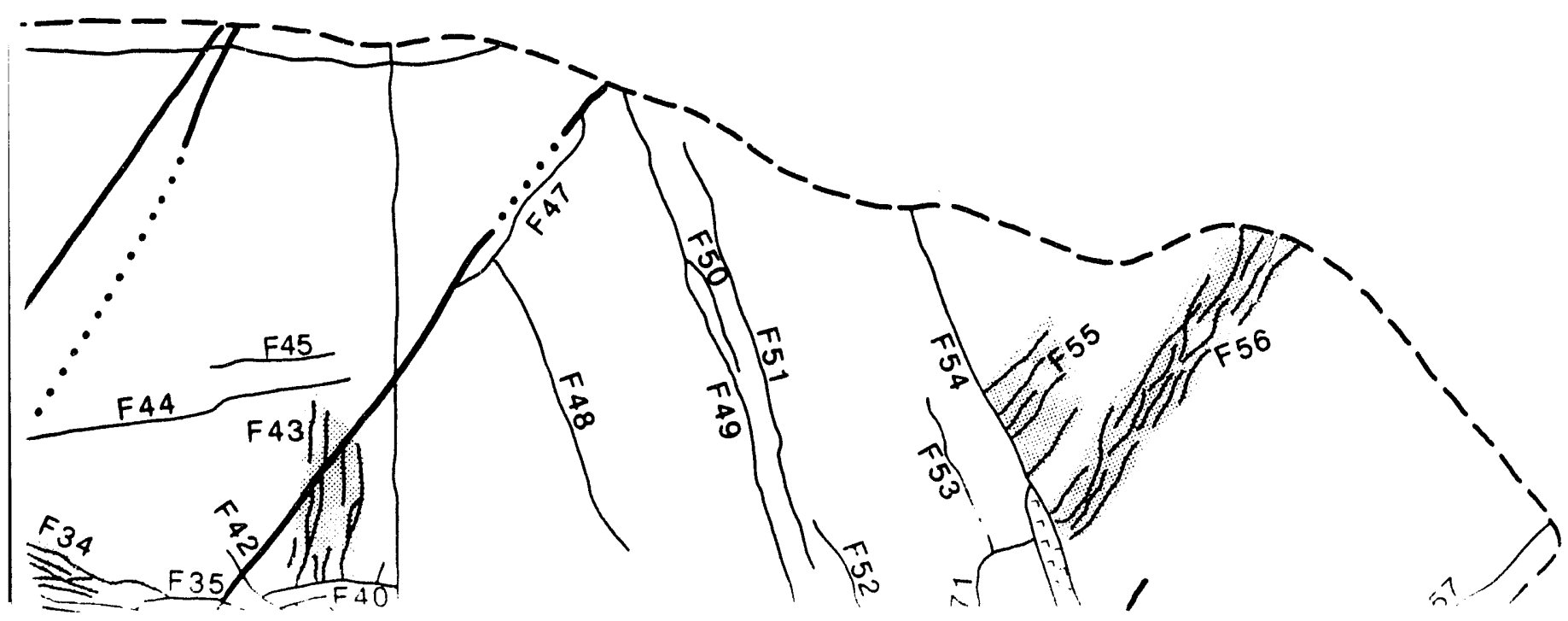




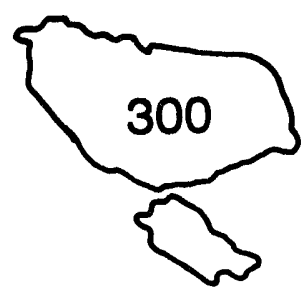

iame scale
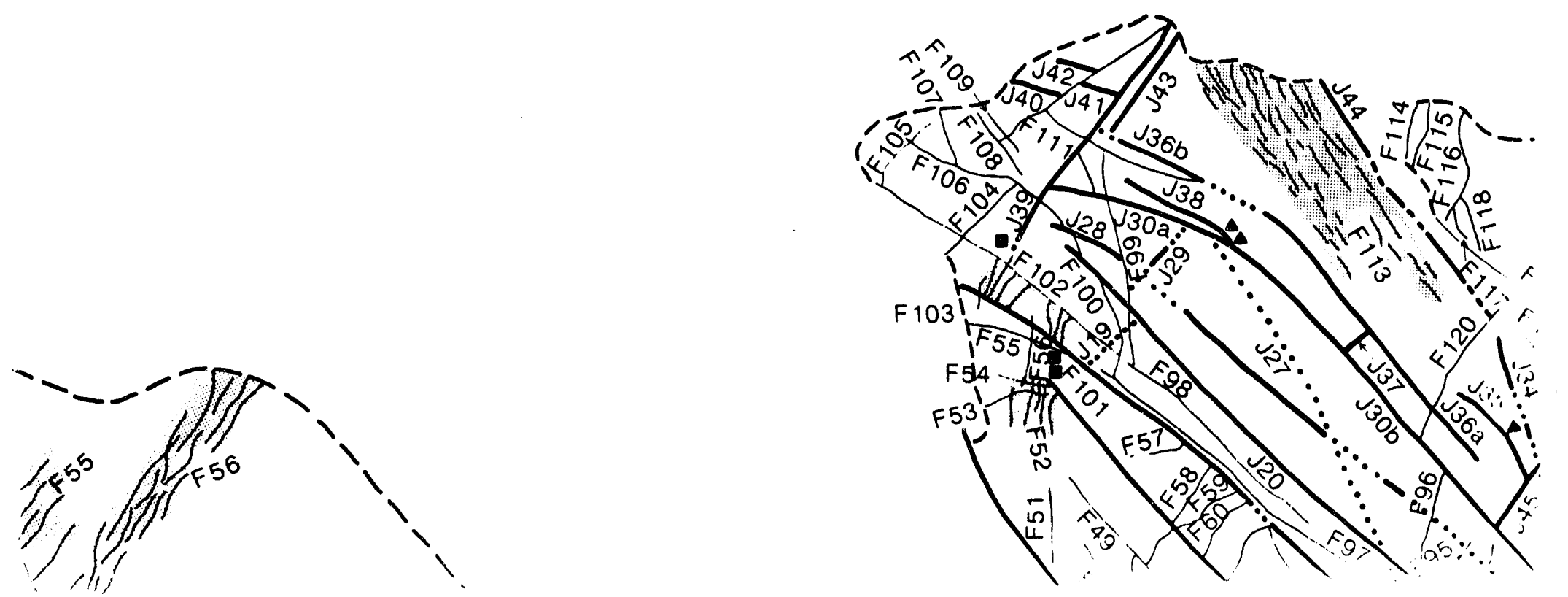


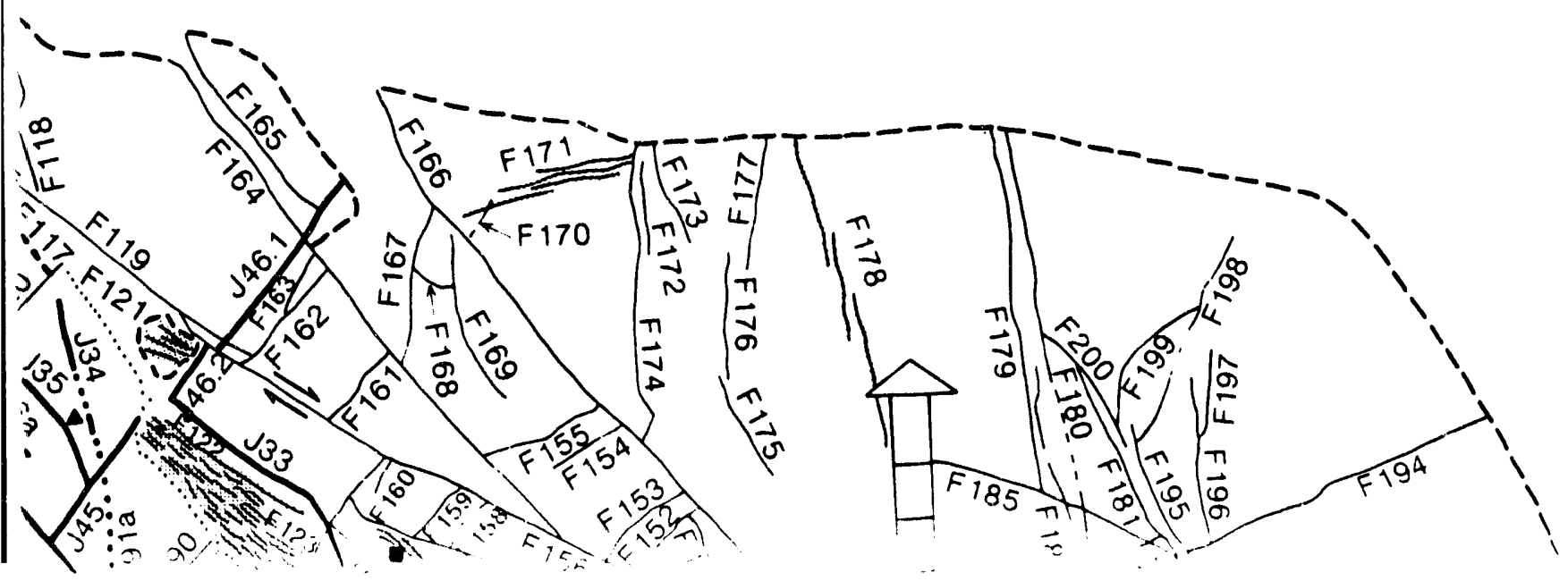




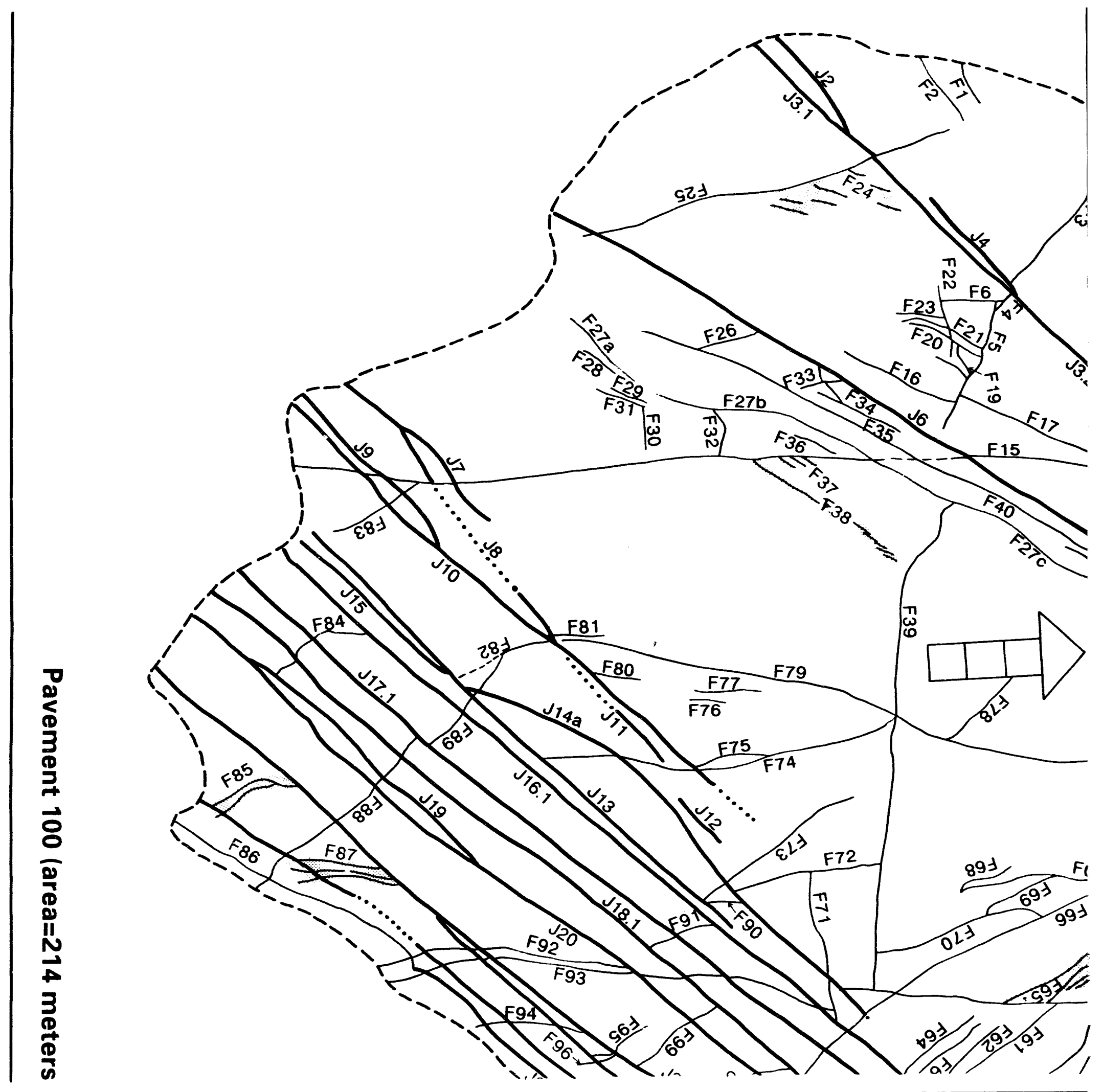




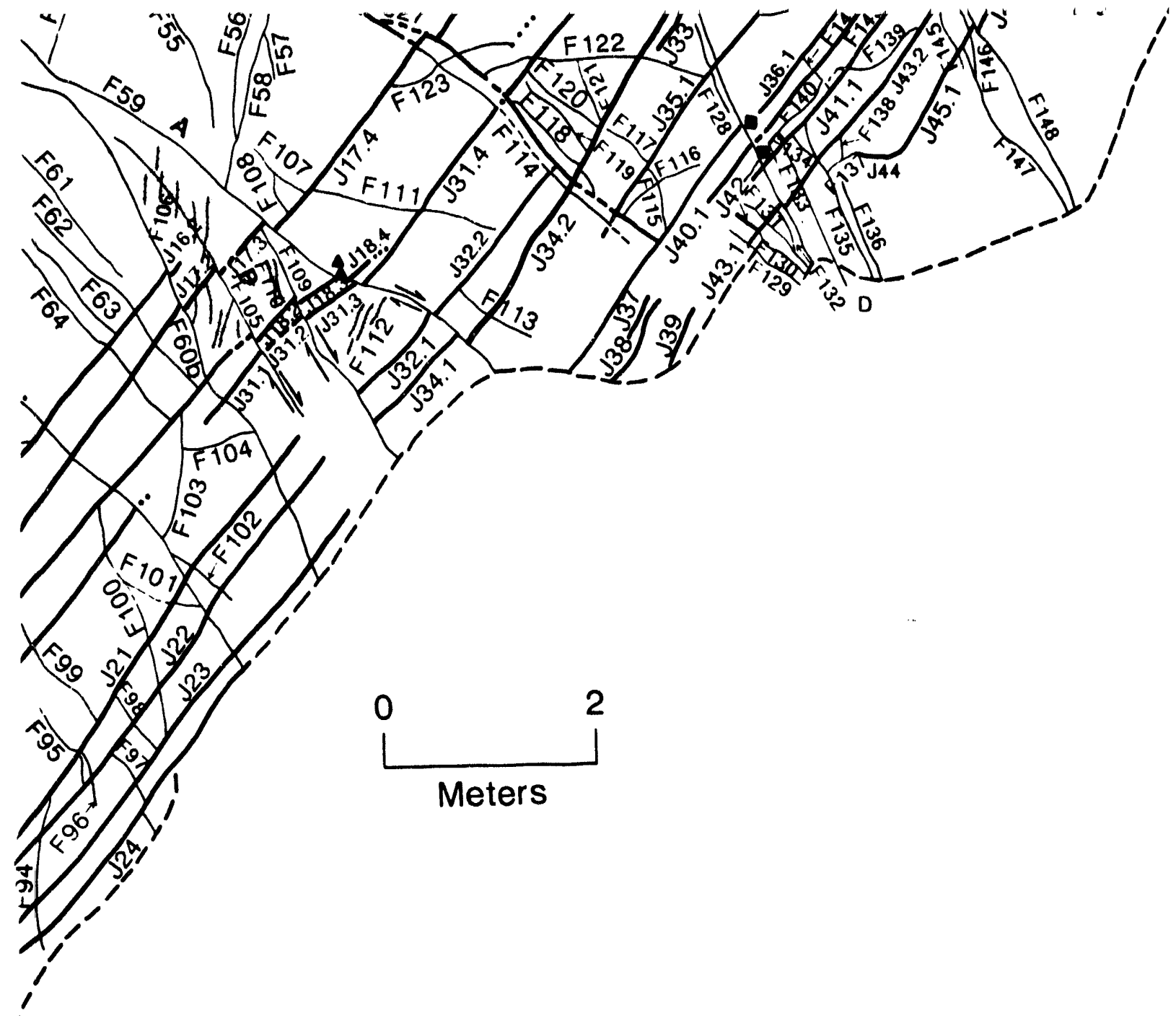

leters $^{2}$ ) 


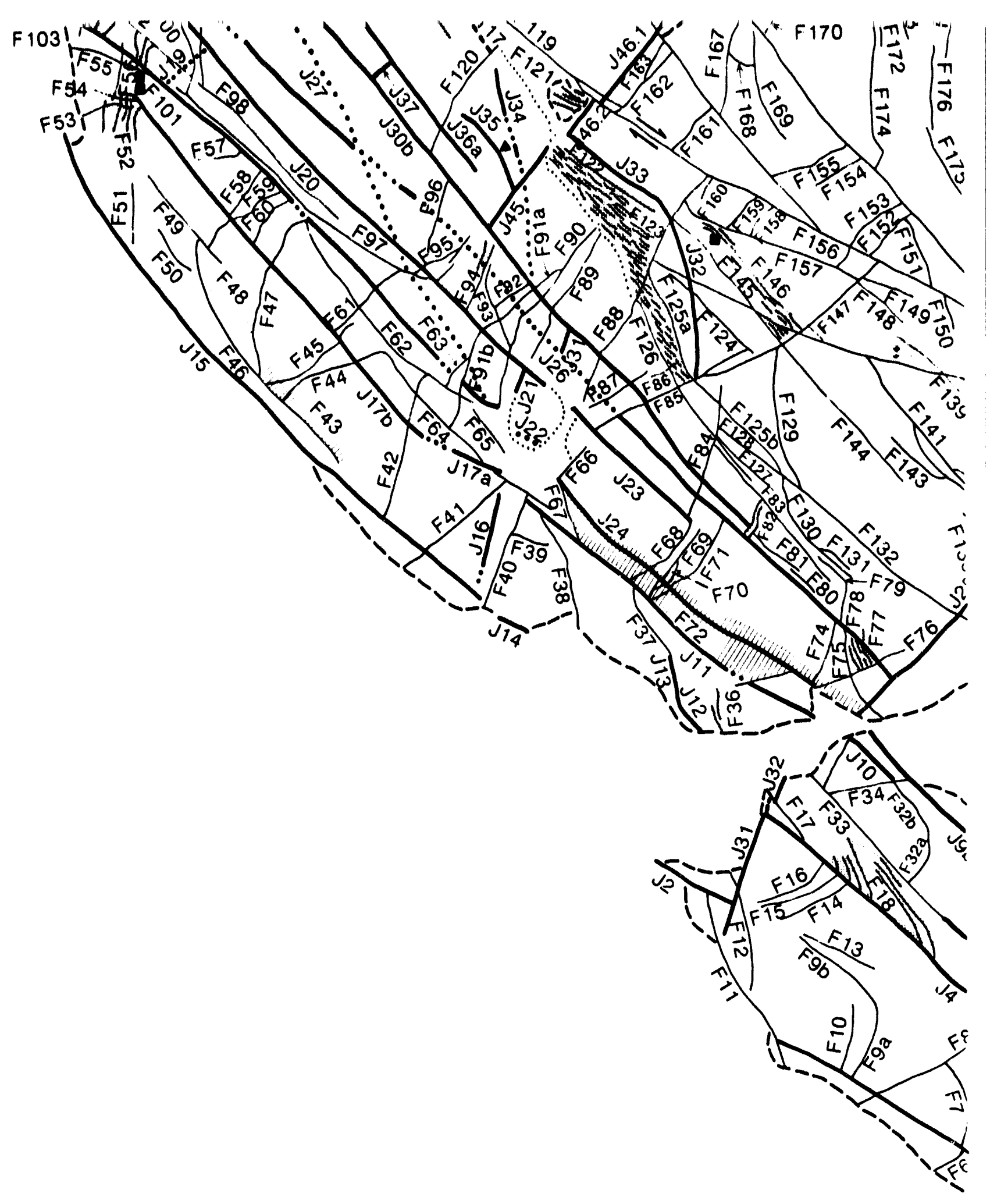




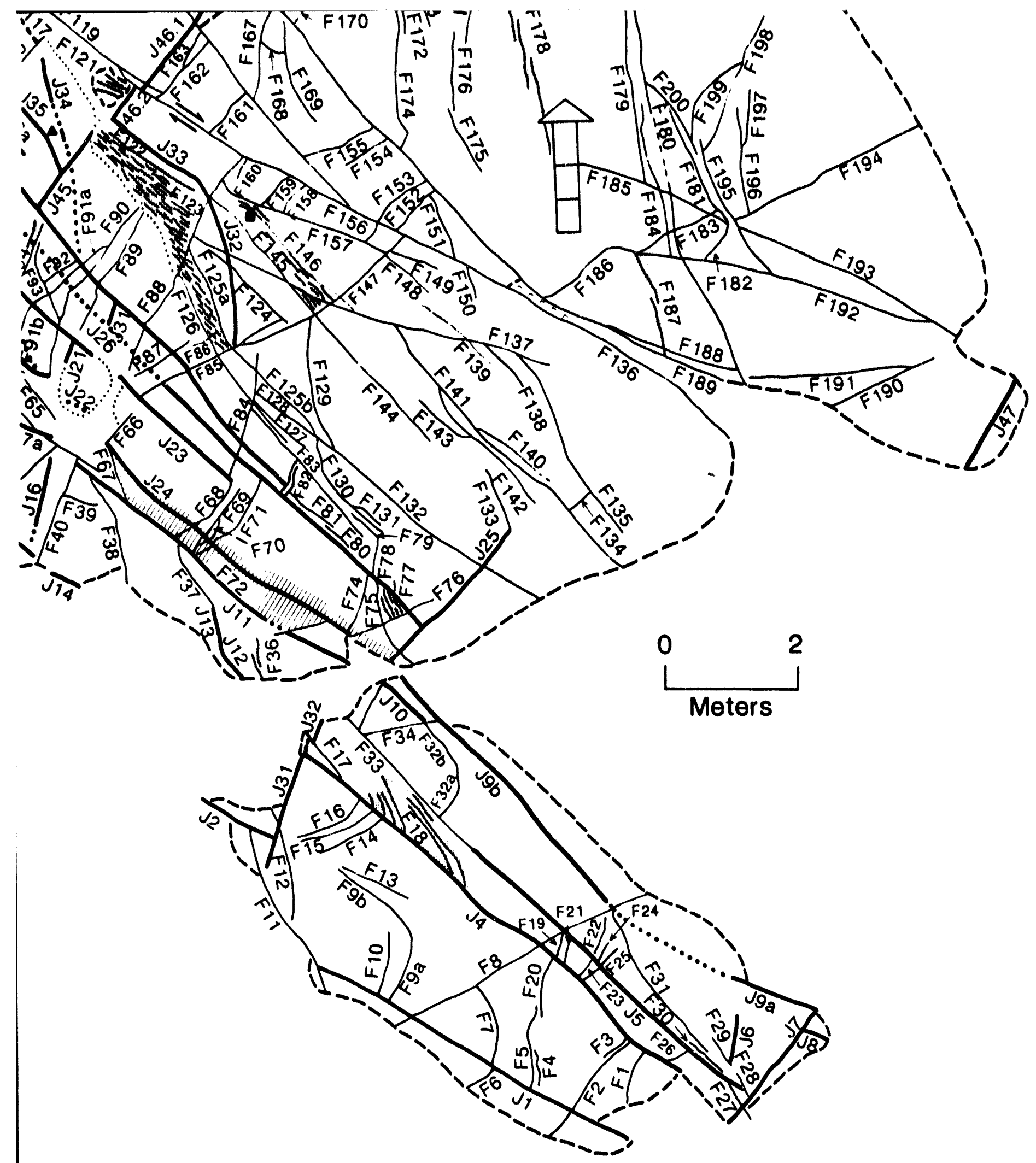

Pavement 300 (area=221 meters $\left.^{2}\right)$

This report is preliminary and has not been reviewed for conformity with U.S. Geological Survey editorial standards or stratigraphic nomenclature 

